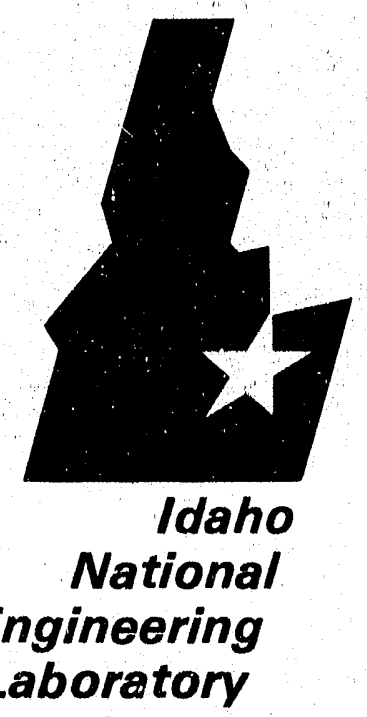

Managed

by the U.S.

Department

of Energy
EGG-WTD-9594 Vol. VI

January 1992

\title{
APR 271992
}

\section{Preliminary Systems Design Study Assessment Report \\ Volume VI: Waste lsolation Pllot Plant and \\ Transportation Package Acceptable Concepts}

\author{
J. L. Mayberry \\ F. Felzollahi \\ J. C. Del Signore
}

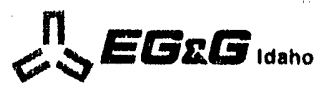

Work performed under DOE Contract No. DE-AC07-761D01570 
This document contains new concepts or the author(s) interpretation of new calculations and/or measurements; accordingly, EG\&G Idaho, Inc. is required by the United States Government to include the following disclaimer:

\section{DISCLAIMER}

This report was prepared as an account of work sponsored by an agency of the United States Government. Neither the United States Government nor any agency thereof, nor any of their employees, makes any warranty, express or implied, or assumes any legal liability or responsibility for the accuracy, completeness, or usefulness of any information, apparatus, product or process disclosed, or represents that its use would not infringe privately owned rights. References herein to any specitic commercial product, process, or service by trade name, trademark, manufacturer, or otherwise. does not necessarily constitute or imply its endorsement, recommendation, or favoring by the United States Government or any agency thereot. The views and opinions of authors expressed herein do no necessarily state or reflect those of the United States Government or any agency thereof. 
EGG-WID- 9594-Vol.6

DE92 012535

\title{
PRELIMINARY SYSTEMS DESIGN STUDY ASSESSMENT REPORT
}

\author{
Volume VI \\ WASTE ISOLATION PILOT PLANT AND \\ TRANSPORTATION PACKAGE ACCEPTABLE CONCEPTS
}

J. L. Mayberry

W. J. Quapp

F. Feizollahi

J. C. Del Signore

Published vanuary 1992

Idaho National Engineering Laboratory

EG\&G Idaho, Inc.

Idaho Falls, Idaho 83415

Prepared for the

U.S. Department of Energy

Office of Environmental Restoration and Waste Management

Under DOE Idaho Field Office

Contract DE-AC07-76ID01570 
PRELIMINARY SYSTEMS DESIGN STUDY

ASSESSMENT REPORT

EGG-WTD-9594

Volume VI

Prepared by:

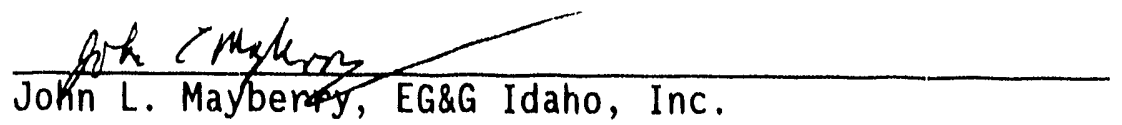

$\frac{|2-23-9|}{\text { Date }}$

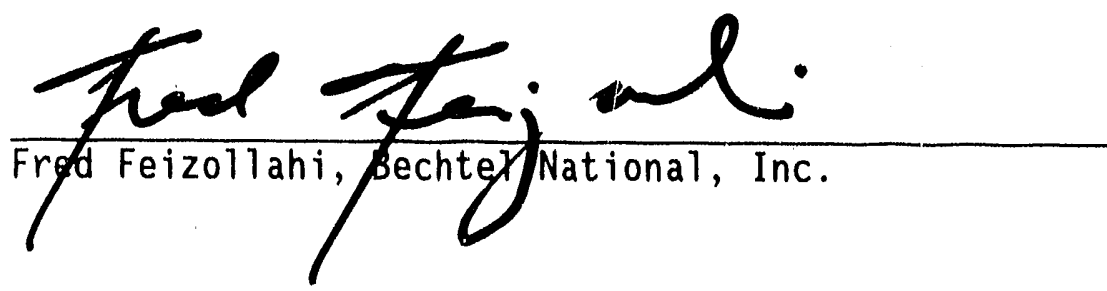

$12 / 2 / 91$

J.C. I.els.

Chris Del Signore, EBASCO

$\frac{12-19-9 \mid}{\text { Date }}$

Reviewed and Approved by:
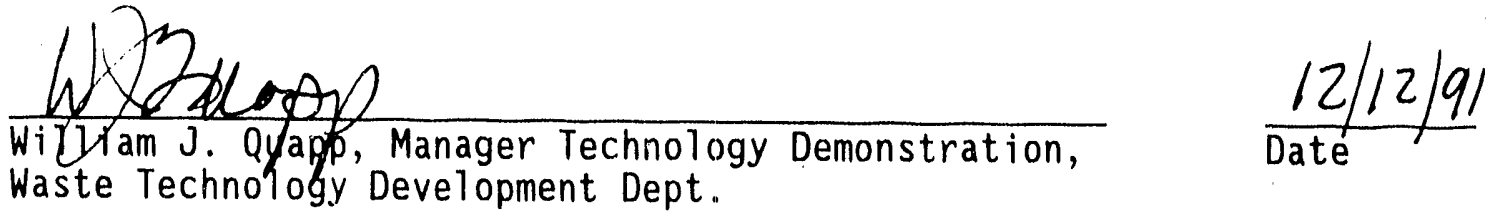


\begin{abstract}
The System Design Study (SDS), part of the Waste Technology Development Department at the Idaho National Engineering Laboratory (INEL), examined techniques available for the remediation of hazardous and transuranic waste stored at the Radioactive Waste Management Complex's Subsurface Disposal Area at the INEL. Using specific technologies, system concepts for treating the buried waste and the surrounding contaminated soil were evaluated. Evaluation included implementability, effectiveness, and cost. The SDS resulted in the development of technology requirements including demonstration, testing, and evaluation activities needed for implementing each concept.
\end{abstract}

The SDS results are published in eight volumes. Volume I contains an executive summary. The SDS summary and analysis of results are presented in Volume II. Volumes III through VII contain detailed descriptions of twelve system and four subsystem concepts. Volume VIII contains the appendixes. 


\section{ACKNOWLEDGMENTS}

The authors would like to acknowledge the efforts of those that contributed to this report.

EG\&G Idaho, Inc., Bechtel National, Inc., Ebasco Environmental, and IT Corp. for providing the assessments and functional and operational requirements for the 12 system and 4 subsystem concepts. Specificaliy, C. Klassy, K. Sherick and D. Haifner of EG\&G Idaho, Inc., R. Schlueter, M. Pong, D. Harris, M. Beathard and P. Yen of Bechtel National, Inc., D. Prinzing, J. Bjorkstam, R. Vankateswar and S. Peck of Ebasco Environmental, J. Plum, J. Valdez, D. Vetter, M. Chavez, S. Djordevic, M. Swientoniewski, John McFee of IT Corp., and H. Kresny of Solmont Corporation.

Karen Grant and Janalee Ne1son of EG\&G Idaho, and Debra Iniquez of Bechtel National, Inc., for the extra effort required in editing this report. 


\section{CONTENTS}

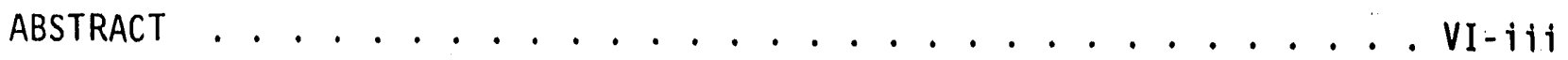

ACKNOWLEDGMENTS .................... . . . . . . . . .

ACRONYMS .......................... . . . . . . . .

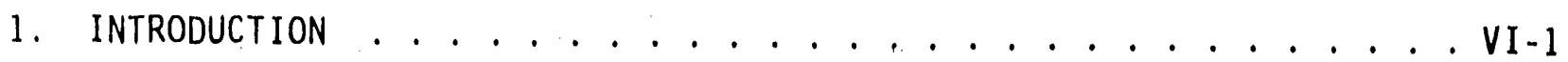

1.1 Background . . . . . . . . . . . . . . . VI-1

1.2 Organization of the System Design Study Report . . . . . . . VI-2

1.3 Content and Organization of this Volume .......... VI-2

1.4 System Concept Limitations . . . . . . . . . . . . . VI-3

1.5 General Considerations and Assumptions Used in System Concepts Development .................. VI-3

1.5.1 Waste Property Assumptions ............. VI-3

1.5 .2 General Assumptions .............. VI-5

1.6 Criteria and Assumptions for Program Implementation Risk

Assessment . . . . . . . . . . . . . VI-5

1.6.1 Project Mission Need and Objectives . . . . . . . . . . VI-6

1.6.2 Technical and Performance Risk Considerations . . . . . . VI-7

1.6.3 Health and Safety Risk Considerations.... . . . . . . . VI-8

1.6.4 Institutional Risk Considerations........... . VI-10

1.6.5 Schedule Risk Considerations . . . . . . . . . . . . VI-10

1.6.6 Cost Risk Considerations . . . . . . . . . . . . . . . VI-11

1.7 Cost Estimating Assumptions . . . . . . . . . . . VI-11

1.7 .1 Cost Estimating Guidelines . . . . . . . . . VI-11

1.7.2 System Model Cost Estimate Normalization and Modification ............... VI-13

1.8 Demonstration, Testing, and Evaluation Assessment

Assumptions .................. VI-14

2. SORT, TREAT, AND REPACKAGE SYSTEM $(4-B E-2) \ldots \ldots$. . . . . . VI-21

2.1 Functional and Operational Requirements .......... VI-21

2.1 .1 System Description .............. VI-21

2.1 .2 System Boundaries .............. . . VI-31

2.1 .3 Process Functional Diagram . . . . . . . . VI-33 
2.1.4 Facility Description .............. VI-33

2.1.5 System Design Requirements ............ . VI-39

2.1.6 Interface Requirements .............. VI-4]

2.2 System Assessment . . . . . . . . . . . . VI-42

2.2.1 Current Status of Unit Operations........... . VI-42

2.2.2 Program Implementation Risks . . . . . . . . . . . . VI-47

2.2.3 Unit Operations Pro and Con Analys is ........ VI-51

2.2.4 Unit Operations Lead-Time Estimates . . . . . . . . . . VI-56

2.2.5 Rough Order of Magnitude Cost Estimates . . . . . . . VI-56

2.2.6 System Evaluation Results ............. . VI-60

2.2.7 Summary of Demonstration, Testing, and Evaluation Needs . . . . . . . . . . . . . . VI-61

2.3 Recommendation for the System .............. VI-67

3. VOLUME REDUCTION AND REPACKAGE SYSTEM (4-BE-4) . . . . . . . . VI-69

3.1 Functional and Operational Requirements .......... . VI-69

3.1.1 System Description ................. VI-69

3.1.2 System Boundaries................. VI-79

3.1.3 Process Functional Diagram . . . . . . . . . . VI-80

3.1.4 Facility Description ................ . VI-81

3.1.5 System Design Requirements .. . . . . . . . . . VI-8I

3.1.6 Interface Requirements . . . . . . . . . . . . VI-88

3.2 System Assessment . . . . . . . . . . . . . VI-90

3.2.i Current Status of Unit Operations........... VI-91

3.2.2 Program Implementation Risks . . . . . . . . . . . . VI-95

3.2.3 Unit Operations Pro and Con Analys is ......... VI-101

3.2.4 Unit Operations Lead-Time Estimates . . . . . . . . . VI-104

3.2.5 Rough Order of Magnitude Cost Estimates....... . VI-104

3.2.6 System Evaluation Results .............. . VI-108

3.2.7 Summary of Demonstration, Testing, and Evaluation

Needs . . . . . . . . . . . . . . VI-111

3.3 Recommendation for the System .............. . VI-111

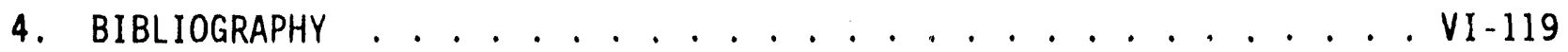

\section{FIGURES}

VI-1-1. Categories of work effort and research and development or acquisition phases............... VI-16 
VI-1-2. Breakdown of demonstration, testing, and evaluation activities during advanced development . . . . . . . VI-18

VI-2-1. Process functional diagram for the Sort, Treat, and Repackage System $(4-B E-2) \ldots \ldots$ VI-35

VI-2-2. General arrangements for the Sort, Treat, and Repackage System $(4-B E-2) \ldots \ldots$............. VI-37

VI-3-1. Process functional diagram for Volume Reduction and Package System $(4-B G-4) \ldots \ldots$................ VI 83

VI-3-2. General arrangements for the Waste Receiving, Processing, and Packaging Facility............. VI-85

\section{TABLES}

VI-2-1. 4-BE-2 summary of program implementation risks and major areas of concern ................ VI-48

VI-2-2. DT\&E assessment summary for the Sort, Treat, and Repackage System (4-BR-4) ................. VI-57

VI-2-3. Rough order of magnitude cost estimates (4-BE-2) . . . . VI-58

VI-2-4. Rating performance measurables for the Sort, Treat, and Repackage System (4-BE-2) ............ VI-62

VI-2-5. DTAE needs for the Sort, Treat, and Repackage System $(4-B E-2) \ldots \ldots$. . . . . . . . . II-63

VI-3-1. 4-BE-4 summary of program implementation risks and major areas of concern ................. VI-96

VI-3-2. DT\&E assessment summary for the Volume Reduction and Packaging System $(4-B E-4) \ldots \ldots$. . . . . . . . . 105

VI-3-3. Rough order of magnitude cost estimates (4-BE-4) ..... VI-106

VI-3-4. Rating performance measurables for the Waste Volume Reduction and Packaging System (4-BE-4) ....... VI-110

VI-3-5. DT\&E needs for the Waste Volume Reduction and Packaging System $(4-B E-4) \ldots \ldots$.............. VI 112 
VI-Viji 


\section{ACRONYMS}

AEC

ALARA

ANL-W

ARAR

CAA

CCD

CDIF

CEA

CEPOD

CEQ

CERCLA

CFR

CM

CWA

DOD

DOE

DOE-ID

DOT

dscf

DT\&E

EG\&G Idaho

EM

EOF

EPA
U.S. Atomic Energy Commission

as low as reasonably achievable

Argonne National Laboratory-West

applicable or relevant and appropriate requirement

Clean Air Act

charged coupled device

Component Development Integration Facility

Atomic Energy Commission (France)

catalytic electrolytic plutonium oxide dissolution

Council of Environmental Quality

Comprehensive Environmental Response, Compensation, and Liability Act

Code of Federal Regulations

construction management

Clean Water Act

U.S. Department of Defense

U.S. Department of Energy

Department of Energy-Field Office, Idaho

U.S. Department of Transportation

dry standard cubic feet

demonstration, testing, and evaluation

EG\&G Idaho, Inc.

electromagnetics

energy optimizing furnace

U.S. Environmental Protection Agency

VI- ix 


$\begin{array}{ll}\text { ER } & \text { environmental restoration } \\ \text { ERDA } & \text { Energy Research and Development Administration } \\ \text { ERP } & \text { Environmental Restoration Program } \\ \text { F\&OR } & \text { functional and operational requirement } \\ \text { FFBD } & \text { functional flow block diagram } \\ \text { FOM } & \text { Figure of Merit } \\ \text { FS } & \text { feasibility study } \\ \text { FY } & \text { fiscal year } \\ \text { GPR } & \text { ground penetrating radar } \\ \text { HAZMAT } & \text { hazardous material } \\ \text { HEPA } & \text { high-efficiency particulate air (filter) } \\ \text { HVAC } & \text { heating, ventilating, and air conditioning } \\ \text { IAG } & \text { Interagency Agreement } \\ \text { INEL } & \text { Idaho National Engineering Laboratory } \\ \text { I/O } & \text { input/output } \\ \text { ISV } & \text { in situ vitrification } \\ \text { LANL } & \text { Los Alamos National Laboratory } \\ \text { LDR } & \text { land disposal restriction } \\ \text { LLNL } & \text { Lawrence Livermore National Laboratory } \\ \text { LLW } & \text { low-level waste } \\ \text { MAF } & \text { moisture and ash-free fraction } \\ \text { MF } & \text { melting furnace } \\ \text { MSA } & \text { Major System Acquisition } \\ \text { MSO } & \text { Molten Salt Oxidation } \\ \text { MSW } & \text { municipal solid waste } \\ \text { NEPA } & \text { National Environmental Policy Act of } 1969 \\ & \end{array}$




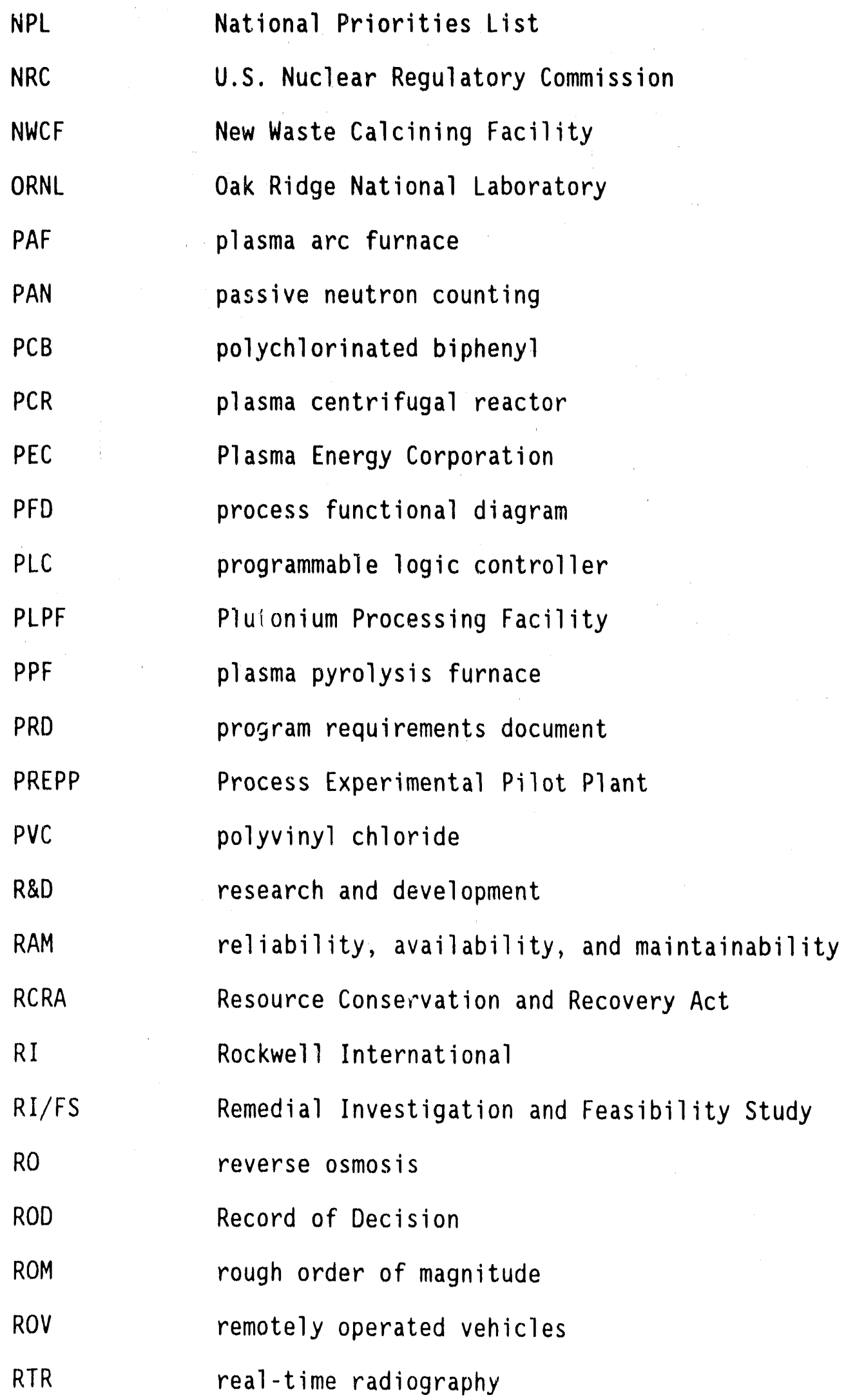




\begin{tabular}{|c|c|}
\hline RWMC & Radioactive Waste Management Complex \\
\hline SAIC & Science Applications International Corporation \\
\hline $\operatorname{scfm}$ & standard $\mathrm{ft}^{3} / \mathrm{min}$ \\
\hline SDA & Subsurface Disposal Area \\
\hline SDS & System Design Study \\
\hline SDWA & Safe Drinking Water Act \\
\hline SEG & Scientific Ecology Group \\
\hline SGS & gamma spectroscopy \\
\hline SWEPP & Stored Waste Examination Pilot Plant \\
\hline TCLP & toxicity characteristic leaching procedure \\
\hline TEC & total estimated cost \\
\hline $\mathrm{T} / 0$ & tradeoff \\
\hline TRAMPAC & transportation package \\
\hline TRU & transuranic \\
\hline TSA & Transuranic Storage Area \\
\hline TSCA & Toxic Substances Control Act \\
\hline TVR-III & Transportable Volume Reduction and Solidification System \\
\hline $\begin{array}{l}\text { UCRL } \\
U / R\end{array}$ & $\begin{array}{l}\text { University of California Research Laboratories } \\
\text { utilization of resources }\end{array}$ \\
\hline VOC & volatile organic compound \\
\hline WAC & waste acceptance criteria \\
\hline WAG & Waste Area Group \\
\hline WERF & Waste Experimental Reduction Facility \\
\hline WIPP & Waste Isolation Pilot Plant \\
\hline
\end{tabular}




\section{VOLUME VI \\ WASTE ISOLATION PILOT PLANT AND TRANSPORTATION PACKAGE ACCEPTABLE CONCEPTS}

\section{INTRODUCTION}

\subsection{BACKGROUND}

Remediating the Idaho National Engineering Laboratory (INEL) transuranic (TRU) buried waste at the Subsurface Disposal Area (SDA) will require a complex set of technologies for safe treatment and disposal of the waste. A key question for achieving the Buried Waste Program objectives is which practical and cost effective technologies could be used as candidates to satisfy the objectives of this program. To provide an answer to this question, a system design study (SDS) was commissioned based on system engineering principles advocated by the U.S. Department of Energy (DOE) order 4700.1. The SDS examined the existing and emerging technologies for cost-effective remediation of the buried waste. Since no one technology can accommodate the complex remedial action process, several technologies were considered as a system. While examining the technology options, the SDS focused on the technology requirements aspect of the systems engineering. The intent was to identify a set of cost-effective, practical, acceptable treatment strategies; develop system concepts encompassing these strategies; and identify technologies within these concepts that will require demonstration, testing, and evaluation (DT\&E).

In addition to developing technology requirements, the SDS concepts were developed so they can be used in future studies for establishing other detailed (derived) system requirements such as input/output (I/0) requirements and utilization of resource $(U / R)$ requirements. 


\subsection{Organization of the System Design Study Report}

The SDS results are published in eight volumes. Volume I contains an executive summary. The SDS summary and analys is of the results are presented in Volume II. Volumes III through VII contain a detalled description and assessment of twelve system and four subsystem concepts. Volume VIII also includes appendixes.

\subsection{Content and Organization of this Volume}

This volume contains an introduction section containing a brief SOS background and 1 ists the general as sumptions and considerations used during the development of the system concepts. The introduction section is followed by sections describing two system concepts that produce a waste form in compliance with the Waste Isolation Pilot Plant (WIPP) Waste Acceptance Criteria (WAC) and transportation package (TRAMPAC) requirements. This system concept category is referred to as Waste Form 4, "WIPP and TRAMPAC Acceptable." The following two system concepts are under this category:

- Sort, Treat, and Repackage System (4-BE-2)

- Volume Reduction and Packaging System (4-BE-4).

Each concept is developed through functional allocation and analysis up to a point that major unit operations are identified. For each concept, first a system description is piesented. The system description section describes the overall system and its functional and operational requirements, boundaries, process functional diagram, facility, and design and interface requirements. This section is followed by a system assessment section consisting of the current status of unit operations, system implementation risks, unit operations pro and con analyses, unit operations lead time estimates, and rough order of magnitude (ROM) cost estimates. Also included is a summary of the system evaluation results. 


\subsection{System Concept Limitations}

The system concepts developed for the SDS are of a preliminary nature. System assessments are qualitative and are based on the judgment of the SDS team members assigned to develop the given system model. It is believed that the current level of detail is adequate to provide input to develop the Buried Waste Program technology requirements and provide a vision for the DT\&E planning process. More detailed development of these models will be needed to support the concept exploration, evaluation, and recommendation phase of the Buried Waste Program.

\subsection{General Constderations and Assumptions Used in System Concepts Development}

\subsubsection{Waste Property Assumptions}

The waste input considered in this study are described in a document titled A Brief Analysis and Description of Transuranic Wastes in the Subsurface Disposal Area of the Radioactive Waste Management Complex at the INEL (see Volume VIII, Appendix A) (Arrenholz and Kright, 1991). The following are additional assumptions concerning the input waste criteria:

- The total volume of waste is $2,325,000 \mathrm{ft}^{3}$; the tortal volume of contaminated soil is $9,734,000 \mathrm{ft}^{3}$. The average density of the waste is $37.23 \mathrm{lb} / \mathrm{ft}^{3}$. The average density of the soil is $116 \mathrm{lb} / \mathrm{ft}^{3}$.

- Forty percent of the actual waste is low-level waste (LLW) (i.e., less than $100 \mathrm{nCi} / \mathrm{g}$ ).

- Ninety percent of the soil is LLW or clean. Soils contain both organic and inorganic hazardous components. 
- All lead wastes are or can be made into LLW. Assume that lead is one percent of the waste by weight.

- Waste coitaining materials that can jeopardize the safety of retrieval and processing operations either exist in small quantities and can be safely handled, or can be segregated out for handling and processing as special material (see below). Examples of waste material in this category are high radiation objects, containers having free liquids, and compressed gas cylinders.

- The removal and treatment of the rock sub-layer are not included in this system analysis.

- Terms used to characterize certain waste types are as follows:

Special material--includes waste that is not suitable for normal processing (i.e., processing capability of the system concept described in this repori) including large objects, high radiation materials, large construction material, and any object requiring special handling and processing not included in the system desian. Processing and handling features for special material are not included in the system models. Special matertal handling, processing, and disposal methods will be decided on a case by case basis.

Large objects--include discarded vehicles, reactor shielding, tanks, etc.

- Large construction material--includes discarded construction material such as concrete slabs, steel beams, sections of brick walls, timber, etc.

High radiation objects - include reactor vessels, piping, pumps, fuel components, etc. 


\subsubsection{General Assumptions}

The following general assumptions used in developing a system concept:

- Plutonium recovery is strictly for TRU reduction, not recycling.

- All TRU waste metals will be decontaminated for vollime reduction.

- The bulk of the soil will be excavated without waste being entrained. A small amount of soil is contaminated by the waste.

- The retrieval will be done inside a building that is classified as a low hazard facility per University of California Research Laboratories (IJCRL) 15910.

- The processing buildings for LLW and TRU are classified as a Solid Radioactive Waste Facility per DOE Order 6430.1A and a moderate hazard facility per UCRI. 15910.

- The operational time span for the processing of the plutoniumcontaminated waste is 10 years.

- Operational assumptions:

$$
\begin{array}{ll}
- & 24 \mathrm{~h} / \mathrm{d} \\
- & 5 \mathrm{~d} / \mathrm{wk} \\
-\quad & 70 \% \text { plant availability during operation } \\
\text { - } & \text { Operational } 240 \mathrm{~d} / \mathrm{yr} .
\end{array}
$$

\subsection{Criteria and Assumptions for Program Implementation Risk AsSESSMEnT}

For each of the system concepts, the programmatic risks associated with implementing the model are assessed. This assessment has attempted to identify the major uncertainties requiring focused work and attention, and has

$$
\text { VI }-5
$$


provided an estimate of the confidence level so that the program can meet the objectives stated in Volume II. The assessment is performed according to the guidelines given in DOE Order 4700.1 for risk assessment during the initial project planning phase. Program implementation risk assessments in this report are qualitative and are based on the judgement of the study team members. Because the buried waste remedial action program is still early in the initial phase of the acquisition process, detailed information for a full analysis does not yet exist. Hence, the qualitative judgments are based on several assumptions, which are presented below.

Each of the unit operations was considered during an initial risk assessment of the system concepts. Then, a composite risk level for the overall system concept was assigned based on the risk associated with the unit operations. In most cases, only the overall, system risks are presented in this report. In general, a low ranking implies that the system could be implemented now with virtually no risk. Assignment of moderate rank means that although the implementation of the system concept is feasible, certain aspects of implementation still need to be resolved. If a system concept has a considerable amount of uncertainty regarding achievement of the given objective, then a high risk ranking is assigned.

\subsubsection{Project Mission Need and Objectives}

The project mission need and objectives are given in Volume II. A summary of the objectives is presented below:

- Performance objectives: Baseline cleanup standards for buried waste sites at the Radioactive Waste Management Complex (RWMC) cannot be established until a Record of Decision (ROD) pursuant to the Comprehensive Environmental Response, Compensation, and Liability Act (CERCLA) process is reached for the Remedial Action. These standards will be derived through (a) the Applicable or Relevant and Appropriate Requirement (ARAR) process under CERCLA, (b) standards set by risk assessments, and (c) the State and local requirements. 
- Health and safety: Key health and safety objectives are to (a) identify the hazards of the remedial action operation, and (b) provide measures to eliminate, control, or mitigate identified hazards.

- Institutional objectives: Key institutional objectives are to involve the state agencies and the public in the process of selecting a remedial action for the burted waste and ensure compliance with the National Environmental Policy Act of 1969 (NEPA) and CERCLA public participation requirements.

- Schedule objectives: The objective schedule is to reach approval for Title II start by fiscal year FY 1999. This is based on the assumptions that an ROD under CERCLA will be reached by the end of FY 2001. The schedule objective is to complete the Buried Waste Program by FY 2019.

- Cost objective: At this time, the cost objective for the Buried Waste Program is cost-effectiveness. A baseline budget including cleanup costs has not yet been established.

\subsubsection{Technical and Performance Risk Considerations}

The following considerations were used in characterizing the technical performance risks:

- Contamination type and size: The TRU waste buried at RWMC has been characterized for this study (see Volume VIII, Appendix A). Based on these waste characteristics, the risks are characterized relative to the ability to comply with the performance objectives. However, it should be noted that detailed and accurate information on the materials buried at each of the trenches and pits or the extent of the site contaminants does not exist at this time. If found, pyrophoric materials and compressed gas cylinders 
containing volatile and toxic gases can have a significant impact on the performance compliance risk characterization.

- Major ARARs for in situ treatment options: Major ARARs for in situ options are Resource Conservation and Recovery Act (RCRA), DOE, and U.S. Nuclear Regulatory Commission (NRC) regulations and guidelines for disposal of waste in shallow land burial sites [10 Code of Federal Regulation (CFR) 61].

- ARARs for thermal processes: Major ARARs for thermai processes are the Clean Air Act, and RCRA and DOE regulations for radiation protection.

\subsubsection{Health and Safety Risk Considerations}

The following considerations were used to characterize the health and safety risks:

- General construction-related concerns: As with any constructionrelated activity, there will be general health and safety concerns associated with the buried waste cleanup operations. Risk associated with the ability of the program to define and mitigate general construction related to health and safety concerns is believed to be low.

- Radioactive and hazardous material handling concerns: Because of radioactive (including TRU), hazardous, mixed waste contamination of the material that will be encountered during operations, the program will be subject to health and safety concerns with respect to low-level radiation, TRU contamination, and hazardous material exposures. The risk associated with the ability of the program to define and mitigate these health and safety concerns is believed to be moderate for all systems options involving retrieval and processing, and low for all options involving in situ treatment. 
- Criticality: Because of the measurable quantity of plutionium in the buried waste, the program will be subject to health and safety concerns with respect to criticality. The risk associated with the ability of the program to define and mitigate these health and safety concerns is largely dependent on the avallability of techniques to detect $\mathrm{Pu}$ contamination in the waste before it is handled. In this study, it is assumed that such techniques are available for all system models, except those using the ISV process; therefore, the risk is low. For the ISV, the concern is that the melting of the material may result in potential concentration of $\mathrm{Pu}$ in the bottom of the melt. To mitigate this potential safety concern, a non-intrusive assay technique to determine $\mathrm{Pu}$ concentration in the buried waste would be needed. Such a technique is beyond the realm of the existing technology. A preliminary review of criticality in the ISV process, however, suggests that because of the high chemical reactivity of molten $\mathrm{Pu}$ metal and the high melting point and moderate specific gravity of compounds $\left(\mathrm{PuO}_{2}, \mathrm{PuCl}_{3}, \mathrm{PuH}_{4}\right.$, etc.) that would riost likely form, ihe risk of Pu collecting in a quantity and geometry that would allow a critical mass to form is very low. Because of the consequences of such an occurrence, however, the subject should be examined in more depth during the site characterization effort. For this study, the risk to identify and mitigate criticality concerns for the ISV options is considered to be low.

- Pyrophoric and volatile and toxic gas: Since the SDS waste characteristics document (see Volume VIII, Appendix A) does not identify pyrophoric material or compressed gas cylinders containing volatile and toxic gases, the ability of the program to define and mitigate health and safety concerns related to these wastes are not addressed at this time. 


\subsubsection{Institutional Risk Considerations}

The following considerations were used in characterizing the risks:

- Disposing residues after retrieval: Options involving ex situ treatments (i.e., excavation, removal, and disposal) will involve disposal of TRU-contaminated mixed waste. Curruntly, DOE has no disposal space fur these wastes. Therefore, the question of institutional risk of ex situ techniques will require addressing ultimate disposal of the residues. However, since the system boundary for the SDS does not include the Ultimate disposal of the residues, characterization of the institutional risk did not address the disposal question.

- State and public acceptance of leave-in-place options: System leave-in-place options are characterized as a high risk with regard to institutional acceptance. This is due to anticipated opposition by the state and the public. Over the last several years, the State of Idaho and the Federal Government have communicated several times concerning the retrieval and removal of TRU waste buried at the INEL. DOE and its predecessors, the U.S. Atomic Energy Commission (AEC) and the Energy Research and Development Administration (ERDA), have made commitments to the State of Idahn to remove the TRU waste.

- Thermal process public acceptability: Because of past experience in public opposition at other DOE sites (e.g., Rocky Flats), system options involving the incineration process are characterized as a high risk with regard to acceptance.

\subsubsection{Schedule Risk Considerations}

The following considerations were used to characterize the risks: 
- Time avallable for DT\&E: As indicated above, the schedule objective is to reach Title II design by FY 1999. To achleve this objective, it is assuined that detailed information to evaluate the remedial action options is needed by 1996. Therefore, any system concept requiring DT\&E lead-time longer than five years is belleved to be a high risk.

- Thermal system burn test requirements: Because of past experience in lengthy burn tests and the U.S. Environmental Protection Agency (EPA) approval process at other DOE sites (e.g., Rocky Flats and Oak Ridge National Laboratories), system options involving incineration processes are characterized as a moderate risk in regard to compliance with the schedule objectives.

\subsubsection{Cost Risk Considerations}

Since a baseline cost estimate has not been established at this time, the assessment of cost risk is based on how well the program will be able to define the cost of the given system in the future if the system is selected as the preferred option.

\subsection{Cost Estrmating Assumptions}

\subsubsection{Cost Estimating Guidelines}

Cost estimating guidelines were developed to support development of an ROM cost for each system concept. The guidelines included building/space cost per square foot, and design, inspection, and project administration percentages for the various types of building/space. Also included are operating costs to be considered for development of life cycle costs. All costs are presented in FY 1991 dollars, including operating and maintenance costs. 
1.7.1.1 Building Space costs. The building unit rate costs itsted below are based on similar facilities at the INEL. The costs are representative of the building and its support systems, including utilities and site development costs. The Alpha Cell Space building costs include the high-efficiency particulate air (HEPA) filter systems. Special equipment and any additional mechanical or electrical systems needed for the operation of the equipment has not been included in these costs. The unit rates include direct and indirect construction costs. Indirect costs associated with the additional building costs and equipment costs are established to be 20.5 percent of the direct costs.

- High hazard building space

- Moderate hazard building space

- Alpha cell space with one confinement barrier

- Alpha cell space with two confinement barriers

- Retrieval building space
$\$ 650 / \mathrm{ft}^{2}$

$\$ 350 / \mathrm{ft}^{2}$

$\$ 1000 / \mathrm{ft}^{2}$

$\$ 1200 / \mathrm{ft}^{2}$

$\$ 100 / \mathrm{ft}^{2}$

1.7.1.2 Design Inspection and Project Administration Costs. To determine the design, inspection, and project administration costs for each option, the percentages listed below were applied. These percentages are historical averages for types of activities covered by SDS concepts. 
- Contingency on all costs 25\%

- Design costs applied to construction costs (both $30 \%$ demonstration and production)

- Inspection costs applied to construction costs $7 \%$ (both demonstration and production)

- Project administration applied to construction $10 \%$ costs (both demonstration and production)

- Indirect costs applied to total construction costs $20.9 \%$ (both demonstration and production)

- Construction management (CM) and CM reserve $28.7 \%$ (combined percent) applied only to production construction cost

1.7.1.3 Operating Costs. The utility rates and operating rates listed below were established by EG\&G Idaho, Inc. (EG\&G Idaho) for use in the development of life cycle costs. Present day costs were used for the preparation of these estimates. A contingency factor of $25 \%$ was applied to the project subtotal.

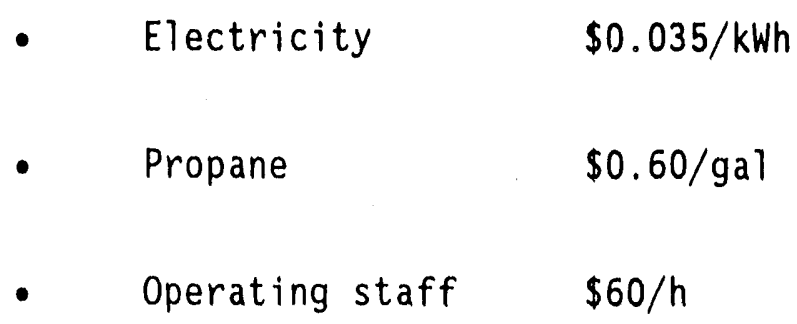

\subsubsection{System Model Cost Estimate Normalization and Modification}

ROM cost estimates were prepared by the team members for the 12 systems and 4 subsystems based on the above guidelines. These initial cost estimates were examined by an independent estimating team to determine if the estimates were comparable in estimating approach and techniques. If not, the estimate approach and techniques were modified so that the estimates could be compared to one another. The independent estimating team corrected the initial estimate inconsistencies concerning the application of multipliers, estimating approach, summary sheets, backup sheets, years of operation, and cost per square foot. The following steps were used to modify the estimates: 
- Normalized costs: The initial ROM estimates for the 12 systems and 4 subsystems were first "normalized" by a consistent application of the multipliers for indirect, design, inspection, project administration, construction management, and contingency. These revised ROM cost estimates were referred to as normalized ROM costs.

- Modified costs: A second review of the 12 system and 4 subsystem model ROM cost estimates was conducted for comparable square footage in allocating the building space, consistent cost per square foot, consistent time basis used in operating and maintenance costs, omissions and errors, and comparable equipment costs with other similar equipment used within the 16 estimates. The ROM cost estimates of the 12 system models were revised to correct any of the above inconsistencies. These estimates were called modified costs. The following modifications were made:

- Because of inconsistent use of criteria, the system models facility sizes were corrected to remove front end receiving, unloading and storage areas, and back end drum storage areas. Space requirements for these functions were assumed to be $200,000 \mathrm{ft}^{2}$ for all ex situ system models. The ROM cost for this space was estimated to be approximately $\$ 30$ million.

- An average square footage for similar operations was developed and used in cases where assignment of alpha cell square footage varied widely for similar operations.

\subsection{Demonstration, Testing, and Evaluation ASSESSMENT ASSUMPTIONS}

Major unit operations in each of the system and subsystem models were evaluated to estimate DT\&E needs, lead-time, and resource requirements. Some of the criteria and assumptions used as the basis for these estimates follow: 
- Project execution: It is assumed that the Buried Waste Program will be executed according to the project management system advocated by DOE Order 4700.1. Figure IV-1-1 shows the various categories of work and the varinus phases of the research and development in a typical project executed under the DOE Order 4700.1 requirements.

- Research and development (R\&D) categories of technologies: It is intended that the 12 system and 4 subsystem options considered in the SDS do not use technologies that fall in the categories of "basic research," "applied research," or "technology or exploration development" as defined in DOE Order 4700.1 (page I-5). Only technologies that have passed the "technology or Exploration development" stage are assessed. Under the EG\&G Idaho Ressearch Development DT\&E Program definitions, technologies considered are assumed to

Have completed R\&D activities to apply knowledge from research toward proof of technology including development of non-specific application prototypes and processes

Require only DT\&E activities to

- Compare the effectiveness of alternative processes

- Determine the applicability of a partic llar technology to a site-specific use

- Establish a level of confidence in a treatment process

- Yield such information as process results, design criteria, and operational sensitivities

- Obtain regulatory agency concurrence or approvals, as needed. 


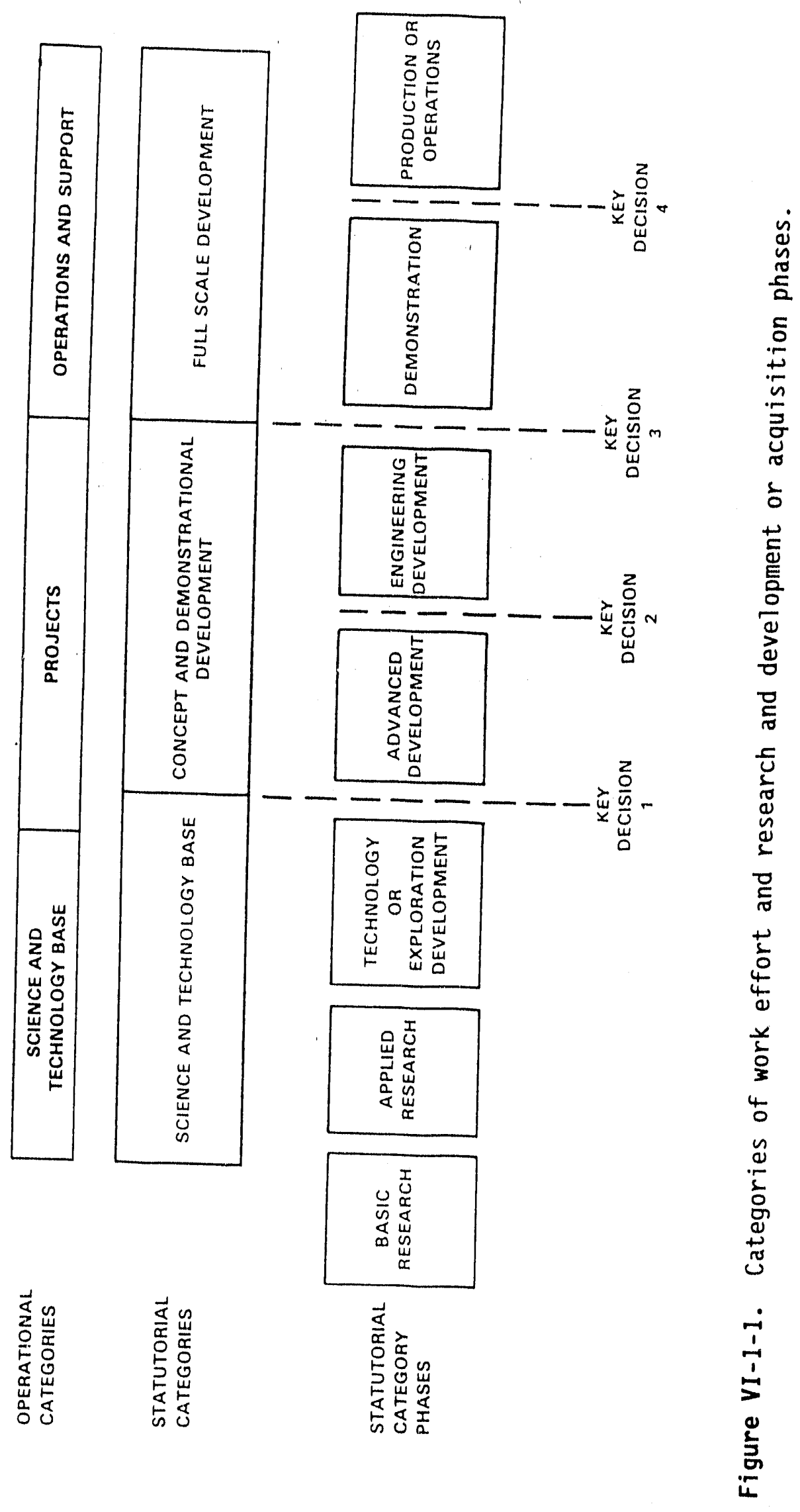

VI - 16 
The EG\&G Idaho DT\&E activities are considered to be comparable to the "advanced development" activities defined in DOE Order 4700.1.

- DT\&E output assumptions: When a DT\&E program is proposed for a given unit operation, the intent is to develop the unit operation to a point where the results will support DOE key decision 2 for the Buried Waste Program. As defined in DOE Order 4700.1, key decision 2 is approval of the start of Title II or final/detailed design activities. In addition, it is intended that the program output will be in accordance with the EPA Guide for conducting Treatability Studies Under CERCLA (EPA, 1989).

- DT\&E steps: In order to allow a consistent assessment of DT\&E needs, the activities are divided into the following logical steps (Figure IV-1-2). These steps are consistent with the EPA Guide for Conducting Treatability Studies Under CERCLA (EPA, 1989).

- Primary paper evaluation: The objective of the primary paper evaluation is to study the various options using existing information. This evaluation will result in defining scope and conceptual design for the next steps of the DT\&E phase. It will eliminate those options that are not likely to be cost effective from further consideration.

- Bench-scale studies: Bench-scale studies are the next logical step, but in some cases it is assumed that the DT\&E efforts can move directly from initial paper evaluation to the pilot-plant/prototype test studies. For example, evaluating a robotics operation in waste segregation would not be conducive to bench-scale studies. If required, these studies will address scaling issues.

Secondary paper evaluation: When further pilot-scale studies are shown to be necessary, a secondary paper including more detailed concept development may be needed. 


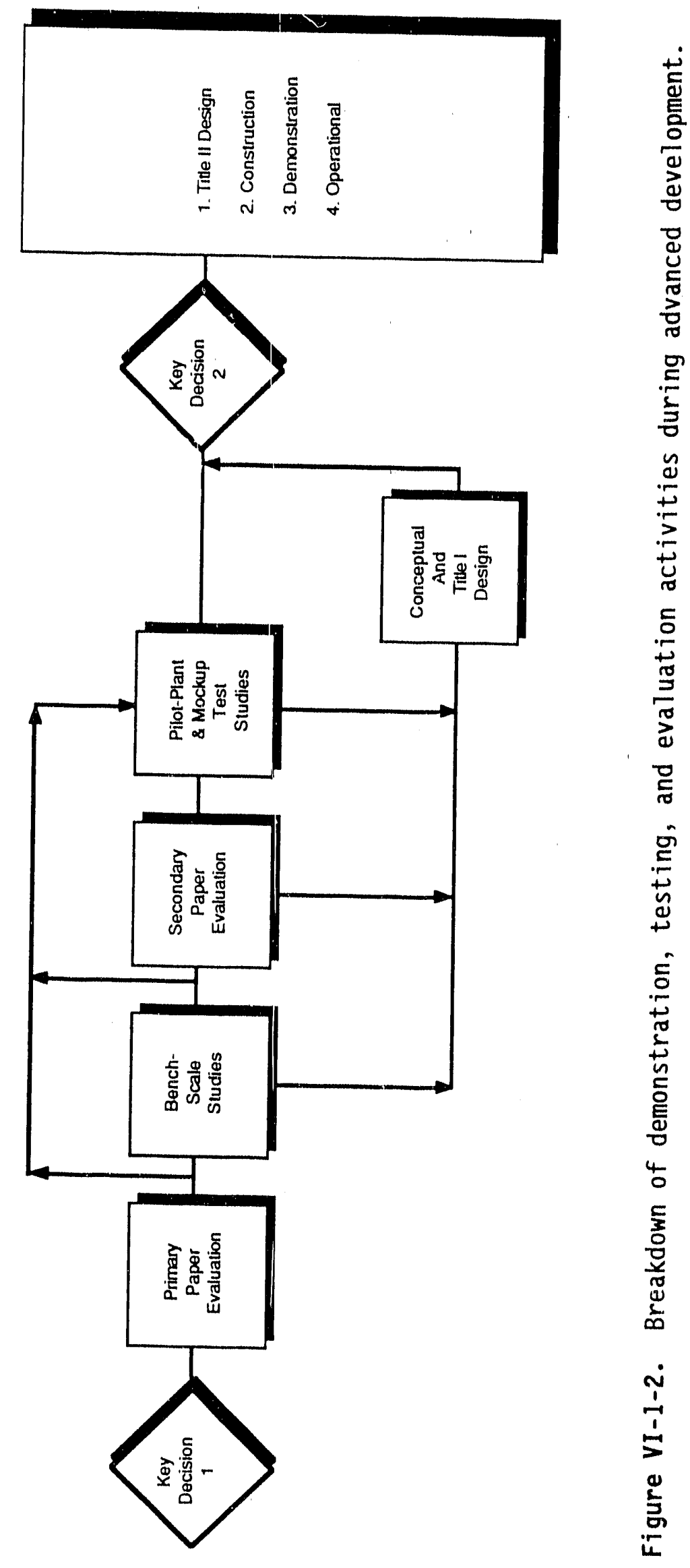


This will help eliminate options that are not cost effective and focus the pilot or prototype test study on essential issues, normally using a single technology option.

- Pilot-plant/prototype test studies: The objective of pilot$\mathrm{plint/prototype} \mathrm{test} \mathrm{studies} \mathrm{is} \mathrm{to} \mathrm{provide} \mathrm{reliable}$ information for developing design criteria including scaleup limitations and cost estimates for processes and ancillary equipment. Fu11-scale prototype tests are assumed for non-process equipment such as robotics development. Generally, pilot-plant/prototype studies are assumed to cover only the critical portions of the equipment requiring advanced development.

- Number of technology options studied in a typical DT\&E program: It is assumed that primary paper evaluation, bench scale studies, and secondary paper evaluation steps will result in narrowing the alternatives to a single option. Pilot-plant/prototype studies are assumed to be applied only to the selected option and are proposed only if it is deemed necessary.

- DT\&E lead-times: In order to provide a consistent estimate of the DT\&E lead-times, a set of timespans is assumed for the DT\&E steps. Based on the complexity of the technologies being considered, the timespan is narrowed down to a specific duration in the assessment sections of the system models. The timespans include allowances for a one-month procurement process and one-month report preparation for bench scale and paper studies. For pilotplant/mock-up studies, a 2-month procurement process, 2-12-month design, 4-12-month fabrication, and 6-24-month test and report preparation are assumed. Based on the above, the assumed timespans are

- Primary paper evaluation

- Bench-scale studies
5-6 months

5-18 months 
- Secondary paper evaluation

5-6 months

- Pilot-plant/mock-up test studies 14-60 months.

$V I-20$ 


\section{SORT, TREAT, AND REPACKAGE SYSTEM (4-BE-2)}

The Sort, Treat, and Repackage System (4-BE-2), includes all facilities, processes, equipment, and ancillary components required for the retrieval, processing, and packaging of TRU waste buried at RWMC. The system retrieves and converts the waste into physical and chemical forms that meet the Waste Isolation Pilot Plant (WIPP) Waste Acceptance Criteria (WAC) and the TRAMPAC-II requirements.

\subsection{Functional and Operational Requirements}

\subsubsection{System Description}

The Sort, Treat, and Repackage System (4-BE-2) is comprised of three subsystems and several unit operations and includes the following:

- Retrieval Subsystem (S-BE-4)

- Solls Processing Subsystem (S-EB-2)

- Metal Decontamination and Sizing Subsystem (S-BE-1)

- Unit operations housed within the Waste Receiving, Processing, and Packaging Facility.

The Retrieval Subsystem provides all the necessary processes and unit operations to retrieve and gross sort the buried waste. The Retrieval Subsystem and its related unit operations are described in Volume VII. There are four major output streams from the Retrieval subsystem:

- Peripheral soil

- Bulk metal 
- Loose material

- Intact containers.

The peripheral soil output is transported via reusable containers to the Solls Processing Subsystem (S-EB-2). This subsystem has all the facilities and equipment needed for treatment and disposal of the contaminated soll. The Solls Processing Subsystem and its related unit operations are described in Volume VII.

The bulk metal output is containerized and transported to the Metal Decontamination and Sizing Subsystem (S-BE-1). This subsystem has all the facilities and equipment needed for treatment of the metal to reduce hydrogen generation potential. The Metal Decontamination and Sizing Subsystem and its related unit operations are described in Volume VII.

Loose material and intact containers (including gas cylinders) are transported to the Waste Receiving, Processing, and Packaging Facility. At this facility, the containers are opened and the waste is removed and processed through a sorting unit. The sorting unit then segregates the waste into metal and nonmetal (includes gas cylinders) streams, with the metal waste stream being sent to the Metal Decontamination and Sizing Subsystem. The nonmetal stream is further sorted into the following categories:

- Soll, combustibles, and noncombustibles

- Organic and inorganic sludge

- Fines, liquid waste, and volatile organic compounds (VOCs)

- Plastic bags

- Compressed gas cylinders. 
Each of the five waste streams are treated by various unit operations according to the specific WIPP-WAC and TRAMPAC-II waste form compliance requitrements.

Combustible and noncombustible wastes are size-reduced and filled into WIPP containers. The fines and liquid waste streams are stabilized by mixing with a solidification agent. The solidified waste is also packaged in WIPP contatners. The plastic bags and compressed gas cylinders are punctured or shredded and then filled into WIPP containers without extensive processing for volume reduction.

Each packaged waste container is processed through a radio-assay and a final certification process. At this point, the containers are certified either as TRU waste or LLW.

Certified containers are sent to an interim storage facility, and shipment of the containers is performed by taking them out of the interim storage area and loading them into transportation over-packs. Over-packs, mounted on shipping vehicles, are used for offsite shipment and disposal.

Descriptions of the unit operations of the Waste Receiving, Processing, and Packaging Facility are presented below.

\subsubsection{Incoming (Unprocessed) Waste Receiving and Opening.}

- Unit operation summary: The receiving portion of the Waste Receiving, Processing, and Packaging Facility processes the incoming waste from the Waste Retrieval Subsystem as follows:

- Unloads the incoming vehicles

- Provides surge storage of the waste contained in reusable containers

- Unloads the reusable containers 
- Uncaps, opens, and dumps the waste contained in the intact containers.

- Reusable containers: The retrieved waste (loose material and intact contatners) will be placed in reusable containers designed for onstte transportation.

- Onsite transportation vehicle: An onsite transportation vehicle will be used to ship the reusable containers from the Retrieval Subsystem to the Waste Receiving, Processing, and Packaging Facility.

- Recelving, unloading, and surge storage: At the Waste Receiving, Processing, and Packaging Facility, the reusable containers will be unloaded from the incoming vehicles and placed in an interim storage area.

- Unloading of reusable containers: Reusable containers will be taken out of the storage area to the container opening and unloading subsystem. This subsystem will remove the reusable container caps and empty its contents.

- Intact drum unloading: A drum unloading device will remove the intact drum caps and feed its contents to the sorting unit. Waste containers containing sludge will be taken directly to the container handling station.

- Reusable container decontamination: The empty, reusable containers will be decontaminated, inspected, and sent back to the Retrieval Subsystem. 


\subsubsection{Sorting (Nonmetal/Metal).}

- Unit operation summary: The sorting unit operation includes all facilities, supporting subsystems, and equipment needed to sort metal objects from the incoming waste stream.

- Coarse sorting: Loose material and contents removed from the intact drums are conveyed to a sorting table (various sorting technologies, such as vibratory tables and air classifiers, may be used). The device will remove and separate bulk metallic objects from the incoming waste stream. The bulk metallic objects will be fed to the Metal Decontamination and Sizing Subsystem. The remaining loose material and any gas cylinders will be processed through a fine sorting device.

- Fine sorting: The first sorting device will contain a separator to remove any remaining metal from the waste stream (various technologies, such as magnetic separation devices, may be used). The metal contents will be diverted to waste containers and transferred to the Metal Decontamination and Sizing Subsystem. The nonmetallic waste, primarily loose material, will be sent to the fine waste sorting device unit operation. Gas cylinders will be sent to the decompression unit operation.

- Fine waste sorting: The second sorting device will segregate the waste into five streams. Various technologies, such as air classification and screening, may be used. Combustibles and noncombustibles will be removed and sent to the size reduction unit operation. Inorganic and organic sludge will be collected and sent directly to the container handling station. Fines and liquid waste will be collected and sent to the solidification unit operation. 


\subsubsection{Size Reduction.}

- Unit operation summary: The size reduction unit operation includes all factlities subsystems and equipment needed to perform the following tasks:

- Convey the waste from the sorting unit operation

- Uncap and empty drums containing loose materials

- Reduce the size of the incoming waste to factlitate container filling and storage.

- Size reduction device: Incoming waste streams from the sorting unit and waste contaifiers containing combustibles and noncombustibles will be dumped into a size reduction unit (e.g., slow speed crusher). The size-reduced waste will be transferred to the container handling station.

- Filled container handling: Incoming waste will be filled into containers, capped, smear tested to determine surface contamination, and washed down (if necessary). The containers will then be sent to the assay/certification station. The liquid waste from the container wash down operation will be discharged into the flush water storage tanks.

2.1.1.4 Sludge Drum Unloading. A drum unloading device will remove sludge drum caps and feed its contents to a container filling station.

- Sludge-filled container handling: The sludge will be poured into containers, capped, smear tested to determine surface contamination, and washed down (if necessary). The containers will then be sent to the assay/certification station. The liquid waste from the container wash down operation will be discharged into the flush water storage tanks. 


\subsubsection{Solidification.}

- Unit operation summary: The solidification unit operation includes all facilities, subsystems, and equipment needed co perform the following:

- Receive and store concentrated liquid waste, fines, and VOC waste

- Receive and store bulk shipments of solidification agents

- Inject solidification agent and waste into a mixing device

- Inject the mixture into waste containers

- Cap the filled waste containers

- Allow curing of the container filled with solidified waste

- Smear test the container surface to determine contamination and, if necessary, decontaminate the container to remove surface contamination

- Transfer the filled containers to the radio-assay and certification station

- Collect and treat flush water generated during system flush and decontamination operations.

- Waste receiving: The incoming concentrate liquid waste and fines will be transferred by pumps to the receiving tanks and silos.

- Solidification storage and feed: The agent used for solidification can be either cement, polymer, or bitumen. The solidification agent storage and feed unit will receive agent from 
bulk shipping vehicles, provide a three-month storage capacity for the bulk material, provide a seven-day operation capacity tank, and provide agent transfer and feed devices. The solidification agent will be metered into the mixing device.

- Mixer: The mixer will mix the waste (a) with the solidification agent, (b) with the mixture being poured, or (c) injected into containers. The mixer will include features for flushing, and the flush water will be collected in tanks and treated for reuse. Concentrated sludge will be solidified.

- Filled container handling: Filled containers will first be set aside for a curing period (24-48 hours). The containers will then be capped, smear tested to determine surface contamination, and washed down (if necessary). The container will be sent to the assay/certification station. The liquid waste from the container wash down operation will be discharged into the flush water storage tanks.

\subsubsection{Vent Bags.}

- Unit operation summary: The venting unit operation includes all facilities, subsystems, and equipment needed to perform the following:

- Convey the waste from the sorting unit operation

- Uncap and empty out drums containing plastic bags

- Shred the incoming waste in a vented chamber to capture released gases

- Reduce the size of the waste to facilitate container filling and storage. 
- Gas removal device: Incoming waste streams from the sorting unit and waste containers containing plastic bags will be dumped into a shredding unit housed in a vented chamber to capture escaping gases. The shredded waste will be transferred to the container handling station.

- Filled container handling: Plastic bags and other waste will be filled into containers, capped, smear tested to determine surface contamination, and washed down (if necessary). The container will then be sent to the assay/certification station. The liquid waste from the container wash down operation will be discharged into the flush water storage tanks.

\subsubsection{Decompression.}

- Unit operation summary: The decompression unit operation includes all facilities, subsystems, and equipment needed to perform the following tasks:

- Convey the waste from the sorting unit operation

- Uncap and empty out drums containing compressed gas cylinders

- Shear or puncture the incoming gas cylinders in a vented chamber to capture released gases

- Reduce the size of the waste to facilitate container filling and storage.

- Decompression device: Incoming waste streams from the sorting unit and waste containers containing compressed gas cylinders will be $\mathrm{placed}$ into a vented chamber and punctured or shredded to release the compressed gases. The shredded waste will be transferred to the container handling station. 
- Filled container handling: Incoming waste will be filled into containers, capped, smear tested to determine surface contamination, and washed down (if necessary). The container will then be sent to the assay/certification station. The liquid waste from the container wash down operation will be discharged into the flush water storage tanks.

\subsubsection{Assay/Certification.}

- Unit operation summary: The assay/certification unit operation includes all facilities, subsystems, and equipment needed to perform the following:

- Determine radioactivity, physical properties, and parameters needed to classify and certify that the waste package is in compliance with transportation and disposal regulations

- Provide interim storage for the packaged waste.

- Radio-assay: Packaged waste (i.e., filled waste containers meeting the ultimate waste form requirements) will be examined by radio-assay devices to allow classification of waste in accordance with the U.S. Department of Transportation (DOT), DOE, and NRC transportation and disposal requirements. Containers will also be weighed. Various devices, such as passive neutron counting (PAN) and gamma spectroscopy (SGS) instruments and load cells, may be used. Data from the examination will be logged and recorded for each container. The radio-assayed containers will first be classified either as LLW or TRU waste. LIW containers will be further classified according to the DOT and NRC requirements and transported to a labeling and LLW certification station. At this station, they will be examined for compliance with shipping and LLW disposal site requirements. Containers classified as TRU will be transported to the TRU certification area. 
- Certification: As a minimum, each LLW and TRU container will be examined by a nondestructive assay using a real-time radiography (RTR) device. The containers will also be smear tested again to determine the extent of any exterior contamination. If the drums are contaminated, a water decontamination process will remove surface contamination. The clean containers will be transferred to an interim storage area.

2.1.1.9 Interim Storage. The system will have a six-month capacity for the storage of TRU and LLW packaged and certified waste containers (i.e., filled waste containers meeting the ultimate waste form requirements).

2.1.1.10 Shipping. The certified waste packages will be transferred from the storage area to the loading station. At this station, the waste packages will be loaded into shipping over-packs, mounted on transportation vehicles, and shipped to the disposal site.

\subsubsection{System Boundaries}

2.1.2.1 Subsystems. The Sort, Treat, and Repackage System (4-BE-2) includes the following subsystems, which are described in Volume VII:

- Retrieval Subsystem (S-BE-4)

- Metal Decontamination and Sizing Subsystem (S-BE-1)

- Soils Processing Subsystem (S-EB-2).

The physical boundaries for the above subsystems are shown in their respective functional and operation requirements (F\&ORs). The boundaries for other unit operations of the Sort, Treat, and Repackage System are given below. 


\subsubsection{Waste Receiving, Processing, and Packaging Facility.}

Physical boundaries: The physical boundaries include the following:

- The Waste Receiving, Processing, and Packaging Facility will be located on a 5 -acre site. The facility boundary is at the site perimeter fence.

- Building foundations including preparation of the site.

- The loading dock is the boundary for the input waste streams.

- The shipping dock is the boundary for the output streams from the facility, with output stream made up of packaged LLW and TRU waste shipments to disposal facilities, nonradioactive solid waste shipments to municipal disposal facilities, and nonradioactive chemical hazardous waste to offsite chemical disposal facilities.

- Utilities: The Waste Receiving, Processing, and Packaging Facility will require services from the service water system and electrical power supply. The system boundaries with the utilities include the following:

- Service water shut-off valves located at the site fence.

- A 4-kV power supply pole located at the fence. Other utilities, such as service air and emergency power, are a part of the Waste Receiving, Processing, and Packaging Facility. 
- Environment: The Waste Receiving, Processing, and Packaging Facility will have the following physical interface with the environment:

- Building ventilation system discharge

- Treated liquid waste evaporation pond

- Sanitary drain field.

\subsubsection{Process Functional Diagram}

2.1.3.1 System Specific Assumptions. Several system-specific assumptions have been made.

- Solidification process increases the volume by a factor of two

- The waste volume is decreased by a factor of two during size reduction

- The waste volume increases by $10 \%$ during packaging

- Six-month storage capacity is needed for the packaged waste.

2.1.3.2 Process Functional Diagram. The mass flow rates and energy requirements for the Sort, Treat, and Repackage System are shown in Figure VI-2-1.

\subsubsection{Facility Description}

2.1.4.1 General Arrangement. General arrangements for the Waste Receiving, Processing, and Packaging Facility are shown in Figure VI-2-2. 


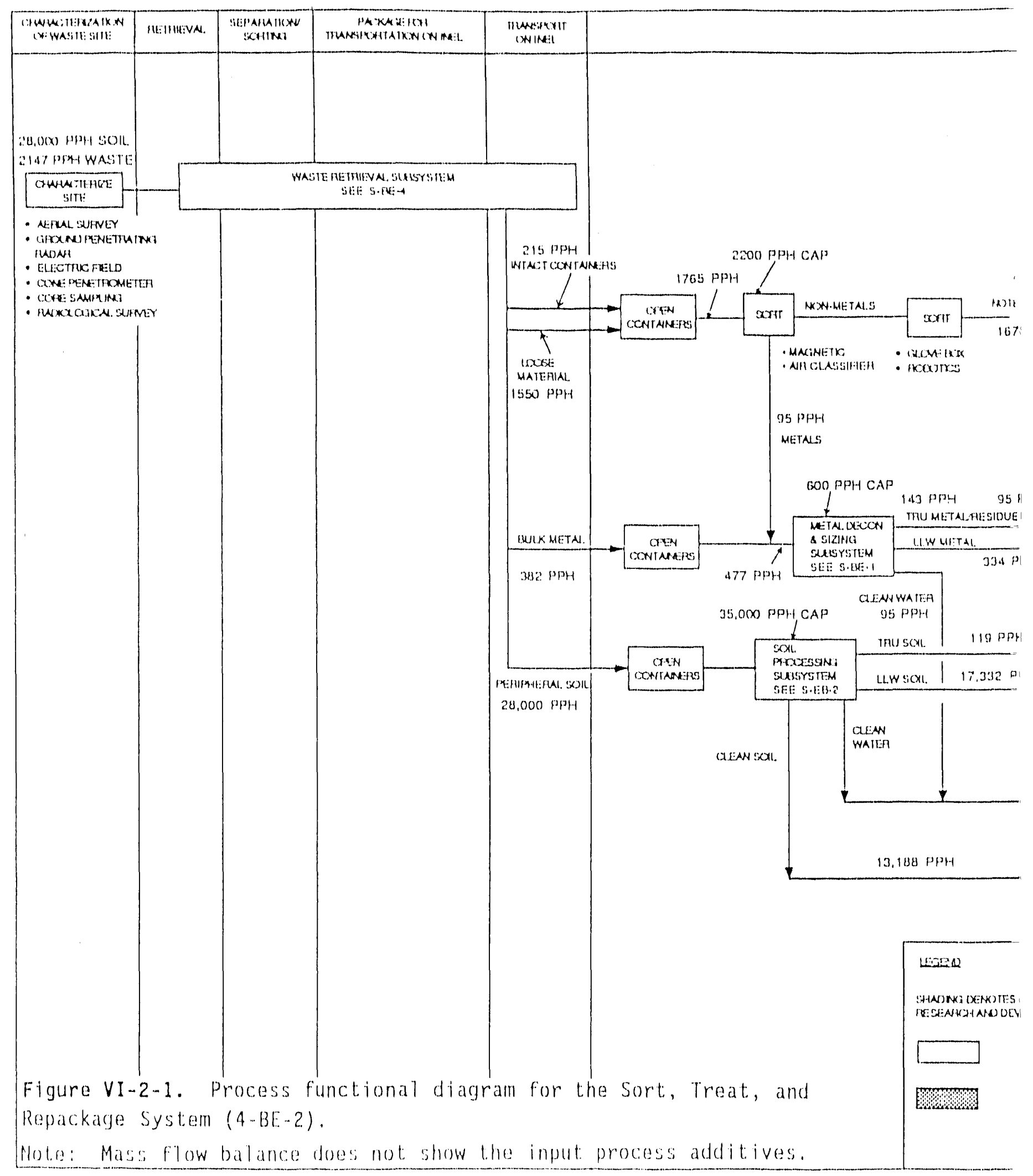




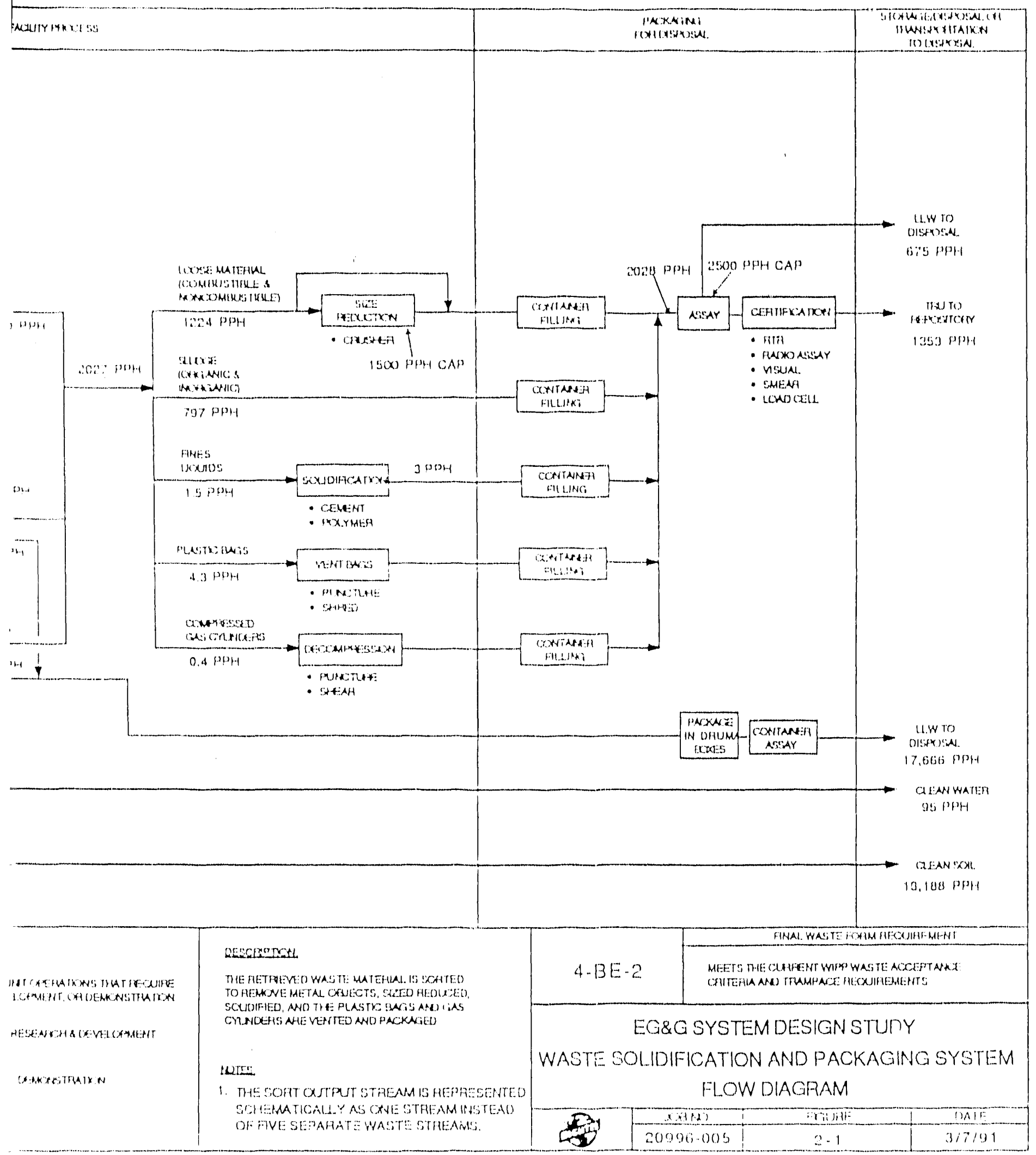




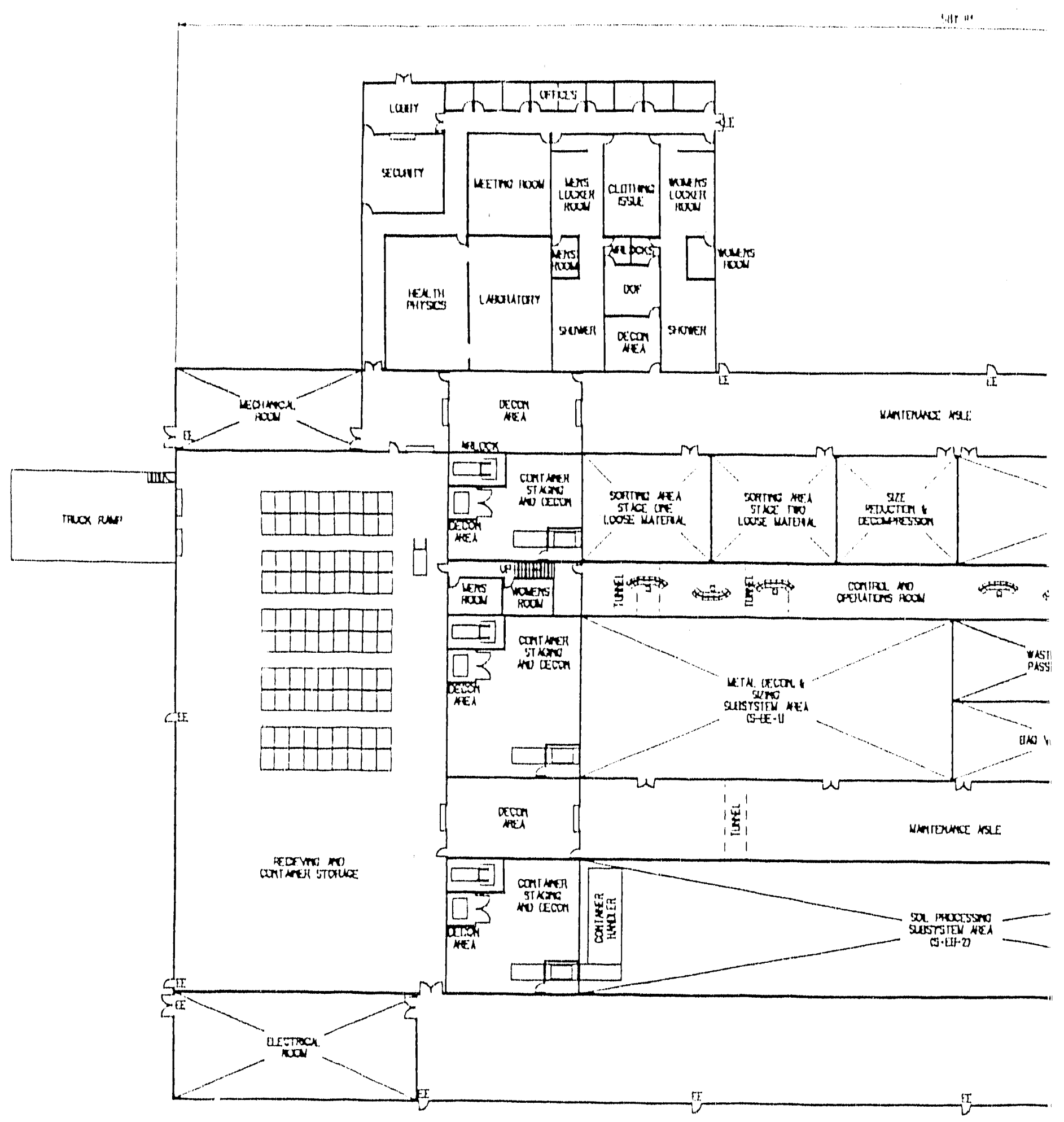

Figure VI-2-2. Ceneral arrangemente for tho sort. Troat, and Repackage System (4-BE-2) 

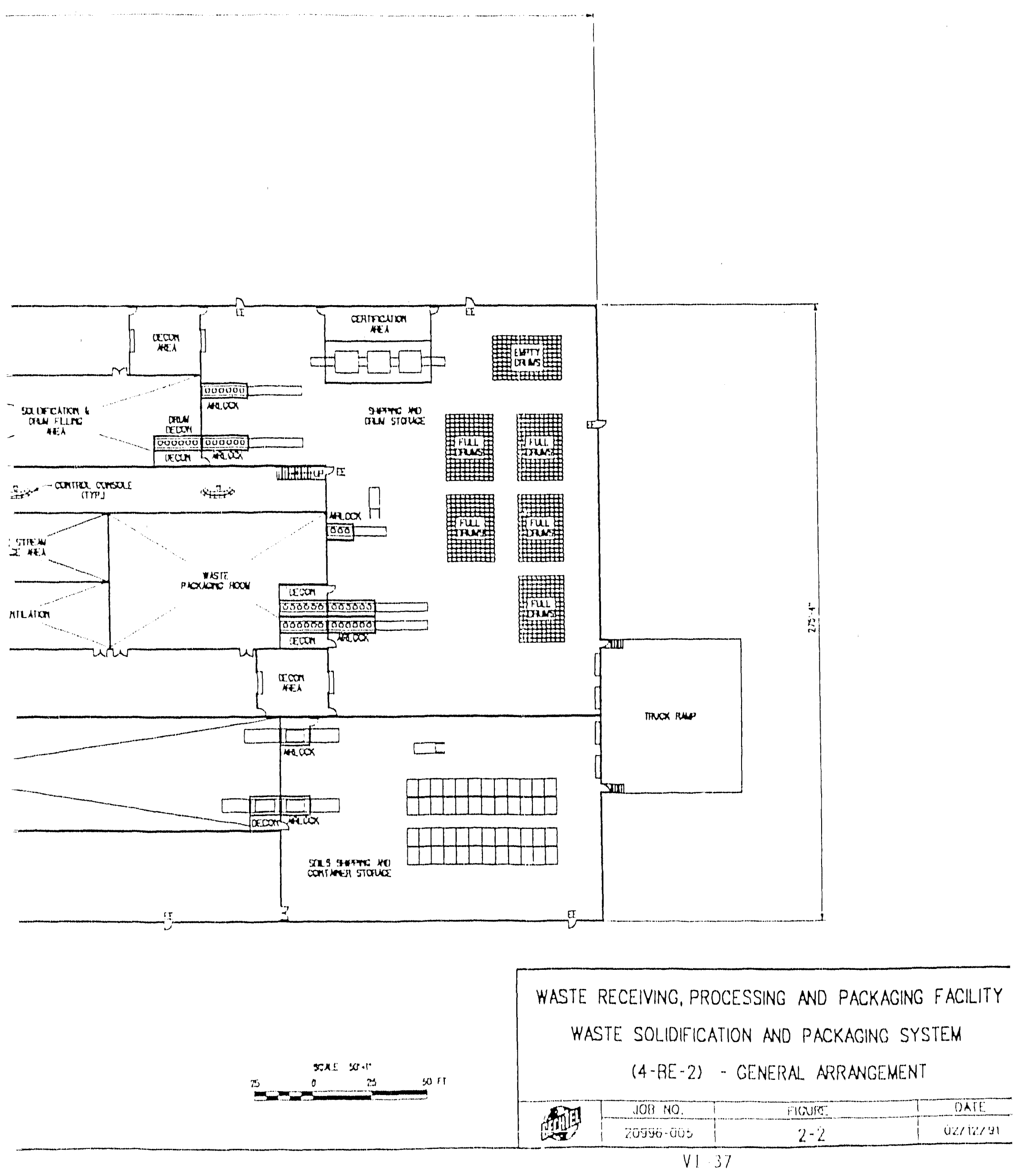
2.1.4.2 Surge Storage Requirements. Storage capacity will be provided for the incoming reusable containers and the final packaged containers. The storage area will contain the following:

- Material handling system

- Fire protection

- Ventilation

- Monitoring per RCRA.

\subsubsection{System Design Requirements}

2.1.5.1 Functional Requirements. The Sort, Treat, and Repackage System should meet the following functional requirements:

- System retrieves buried TRU waste and peripheral soil from RWMC

- The TRU waste and peripheral soil is classified (sorted and processed) within the facility

- The peripheral soil is treated for compliance with the land disposal restrictions (LDRs) requirements

- The TRU waste is converted to a form that meets the WIPP-WAC and TRAMPAC-II requirements.

2.1.5.2 Performance Requirements. The Sort, Treat, and Repackage System should meet the following functional requirements:

- The system capacity will be designed to process and package buried waste from RWMC over a 10-year period 
- Operational availability of 24 hours/day, 5 days/week, and $70 \%$ plant availability during operation, operating 240 days/year

- Packaged TRU waste will meet the WIPP-WAC and TRAMPAC-II requirements

- The system will have the ability to sort and segregate LLW and TRU waste containers

- The system will have the ability to separate metal objects from the waste stream

- The system will minimize the volume of the waste as much as possible

- Impact of the system operation on the environment will be minimal

- The system will be ricensable

- Effect of the system operation on the worker, public health, and safety will be minimal

- The system will have high reliability, operability, and maintainability factors

- The system will have the capability to receive different waste types having a diverse set of characteristics

- The system will have the ability to solidify fines, liquid waste, and VOC waste. 


\subsubsection{Interface Requirements}

The F\&OR sections for the Retrieval Subsystem (S-BE-4), Metal Decontamination and Sizing Subsystem (S-EG-1), and Soils Processing Subsystem (S-EB-2) identify the interface requirements for these subsystems. The following interface requirements are those of the other unit operations of the Sort, Treat, and Repackage System. The flow rate values for the input, output, and intermediate points are given in the process functional diagram, Figure VI-2-1.

2.1.6.1 Support to Other Systems (Output). The Waste Receiving, Processing, and Packaging Facility provides output to the following:

- LLW disposal consisting of output of size reduction, sludges, solidified waste, and decompression

- Metar Decontamination and Sizing Subsystem

- Soils Processing Subsystem

- TRU Geological Repository

- Clean soil

- Exhaust gases from the stack

- Treated water and sanitary waste.

2.1.6.2 Support from 0ther Systems (Input). The Waste Receiving, Processing, and Packaging Facility receives input from the following:

- Retrieval Subsystem (S-BE-4) input includes soil and waste

- Soils Processing Subsystem (S-EB-2) input includes TRU, LLW and clean soil waste 
- Metal Decontamination and Sizing Subsystem (S-BE-1) input includes TRU and $L L W$

- Utilities input includes service water, power, and ventilation input

- Consumables input includes solidification materials, packaging materials, and shipping containers, both disposable and reusable.

\subsection{System Assessment}

The current status, program implementation risks, and a pro/con analysis of the unit operations associated with the Waste Solidification and Packaging system are discussed below. The integration aspects in forming a complete system that satisfies the functional, performance, and interface requirements are complex and may perturb individual unit operations or necessitate DT\&E efforts because of integration problems not previously identified.

\subsubsection{Current Status of Unit Operations}

There are 10 unique unit operations associated with the Waste Solidification and Packaging System (4-BE-2). The unit operations are discussed below.

2.2.1.1 Incoming (Unprocessed) Waste Receiving and Opening. This unit operation receives prepackaged waste from the Retrieval Subsystem (S-BE-4) and integrates subsystems and unit operations of the overall system based on assay and segregation of the waste stream. This unit operation opens the prepackaged containers (reusable), sorts and segregates waste for input into appropriate unit operations, inventories storage and accountability, and uncaps, opens, and dumps waste. Uncapping and opening of incoming containers will be accomplished in an alpha cell environment that has the capability to control dust, drum gas vents, and other hazardous airborne gases and liquids that may leak out of the containers. 
The unit operation will typically consist of a loading dock, a shielded and enclosed workspace, gantry cranes, manipulator systems, drum/container handling systems (repackaging, uncapping, and recapping), and radiologica'l survey instrumentation. Additional automated process components may include an automated bar coding system for accountability and tracking purposes; information management systems for data retrieval, storage, and processing; and material controls that will monitor and quantify output waste streams. Special hoods, dust collection devices, vents, and filters will be provided. Design features will also be provided to collect any potential free liquid that may leak out of the drums and boxes.

The technologies employed in this unit operation are similar to existing material handling and inventory systems currently available commercially. Dust, airborne gases, and free liquid contamination control processes are also existing techniques. However, special designs may be needed to account for unique hazards associated with the chemical and radioactive toxicity nature of the gases and liquids. The integration of automated systems within a controlled environment may require DT\&E. Considerations of reliability, maintainability, and error recovery operations are paramount in the design.

2.2.1.2 Sorting (Nonmetal/Metal). The sorting unit operation is designed to segregate metals from nonmetals and where applicable to further sort by waste type (TRU, LLW, soil, etc.). There is a wide range of technologies and equipment available. These range from simple manual sorting techniques to sophisticated neutron radiography and $x$-ray fluorescence sorting techniques. The equipment employed in the sorting process may include manipulators, screen sieves, tromme1, manual sort (giove boxes), magnetic detection/separation equipment, inductive coil metal detectors, and robotics. On-line radiation detection/assay units and on-line hazardous gas detectors/analyzers may also be used.

The equipment envisioned for this unit operation is commercially available. The integration of the equipment in a controlled environment with appropriate redundancy and error recovery capabilities may require demonstration. 
2.2.1.3 Size Reduction. This unit operation prepares the incoming loose material waste stream for final packaging. The preparation steps include coarse size reduction through shredding or crushing and fine sorting to maximize efficiency in the filling operation. The equipment employed in this unit operation includes sludge drum handling and uncapping systems, a shredder or crusher, and the cryofracture technique, which is used for size reduction of chemical weapons.

These technologies are commercially available and in use by industry. The equipment used in this unit operation is standard commercial equipment and will not require DT\&E beyond its current state. However, demonstration may be required to ensure reliability and maintainability for operation in the alpha cell environment.

2.2.1.4 Sludge Drum Unloading. This unit operation prepares the incoming waste stream for final packaging. The drums containing sludge (without liquid) are sampled, opened, and repackaged into clean certified containers. The equipment used in this process includes drum handling and unloading equipment, certified container loading and packaging, conveyor systems, and slurry transfer systems.

These techniques are well-known. The equipment used in this unit operation is standard commercial equipment and should not require DT\&E beyond its current state. However, DT\&E of the integration of the components to function in an alpha cell environment may be required.

2.2.1.5 Solidification. The solidification unit operation receives fines, liquids, and organic waste and combines them using physical or chemical processes to solidify the materials. The solidified waste is placed in certified containers. The candidate processes are cement solidification, Dow process (solidification of waste in a plastic medium supplied by Dow Chemical), and other polymer processing (solidification of waste in a polymer medium). 
The equipment typically used in these processes includes automated conveyor equipment, container handling equipment, tanks, drums/containers, pumps, siurry equipment, chemical process control equipment, and dewatering equipment.

The processes and equipment are all commercially avallable and in use. Demonstration shows that the solidification process produces a product that satisfies the disposal requirements.

2.2.1.6 Vent Bags. This process involves the collection and removal of vapors and gases as a result of puncturing the plastic bags. Shredders and mechanical puncturing devices may be used.

The equipment used in this process would be adapted from commercially available equipment. The application of this unit operation would require prior information regarding the contaminant, the degree of contamination, and the desired decontamination factor. Further, the treatment of the exhaust gas by either condensation and/or incineration may be required to neutralize the extracted contaminant(s).

Because the process is sensitive to the type of contaminants and its degree of adsorption to the base material, pilot-plant studies would be required to determine the appropriate controlling parameters for detection of gases and removal. Demonstration of the equipment operation within an alpha cell enclosure may be required.

2.2.1.7 Decompression. The decompression unit operation is intended to depressurize and shred or otherwise volume-reduce compressed gas cylinders. A wide range of technologies may be employed to process the gas cylinders. These include cryogenics, a crusher/shearer, a slow speed shredder, plasma torch cutting, electrical discharge cutting, mechanical cutoff saws, manual or automated venting devices, and certified container filling and handling equipment. 
The most significant aspect of this unit operation is the control, venting containment, and processing of hazardous pressurized gases. Identifying cylinder contents is a paramount safety concern. Before processing, this identification should be conducted if possible. The decompression station should be housed etther in a pressure vessel or a vented chamber.

These techniques are well-known and in current use by industry. The equipment used in this unit operation is standard and commercially avallable.

2.2.1.8 Assay/Certification. The assay/certification unit operation examines and quantifies the radioactive physical properties of the fllled containers to determine proper classification and adherence to the appropriate regulations for the hazardous material, and to ensure compliance with current transportation and disposal regulations. The equipment employed in this unit operation includes passive neutron detection, gamma spectroscopy/multichannel analysis equipment, gross gamma detectors, real-time radiography, visual inspection equipment, surface contamination measurement equipment, automated handling systems, and container labeling and tracking equipment.

This unit operation is expected to confirm knowledge already collected during the processing of all waste streams and final package operations. Final verification of waste form (LLW or TRU) will be conducted at this time. Final labeling, material accountability tags, and transportation/storage compliance certification will be accomplished during this process step.

The components of this unit operation are all commercially available and currently in use. Knowledge of the waste form for an algorithm is required. There may be a design effort involved in the integration of these components to accurately assay the waste.

2.2.1.9 Interim Storage. This unit operation should consist of a clean environment on a controlled area/pad and should be regulated and monitored to ensure compliance with local and/or broad agency radiological regulations. The storage area is serviceable by remote and contact handling equipment that 
has the capability to read container labels. This untt operation is simflar to any industrial warehouse operation that is commerctally available.

2.2.1.10 Shipping. This unit operation is intended to be the external interface of the processing subsystems to the final waste disposition. The shipping station wi11 prepare bills-of-lading for the inspected/certified waste containers. Where necessary, the containers will be overpacked to meet appropriate transportation 1imttations. These techniques are well-known, commercially avatlable, and in current use by industry.

\subsubsection{Program Implementation Risks}

This section identifies major concerns associated with program implementation if the Sort, Treat, and Repackage System is selected. Furthermore, risk of accomplishing the program objectives is qualitatively characterized. A summary of results and major areas of concern is shown in Table VI-2-1. Program mission and objectives are given in Volume II.

\subsubsection{Performance Objectives. Baseline cleanup standards for SDA} pits and trenches at RWMC cannot be established until an ROD pursuant to the CERCLA process is reached. These standards will be derived ARARs under CERCLA, standards set by risk assessments, and the State and local statutes. Since no specific requirements have been formally established at this time, it is assumed that the major ARARs for this system will be RCRA rules, the appropriate NRC regulations and guides, and DOE regulations and Orders.

In the Sort, Treat, and Repackage System, the major uncertainties 1isted below have been identified as areas of concern in the achievement of the performance objectives:

- Alpha cell designs for normal and postulated accidents. Alpha cells will be needed to contain Pu-contaminated dust and any radioactive, hazardous, toxic, and volatile gases that may become airborne during the waste handling and processing operations. 


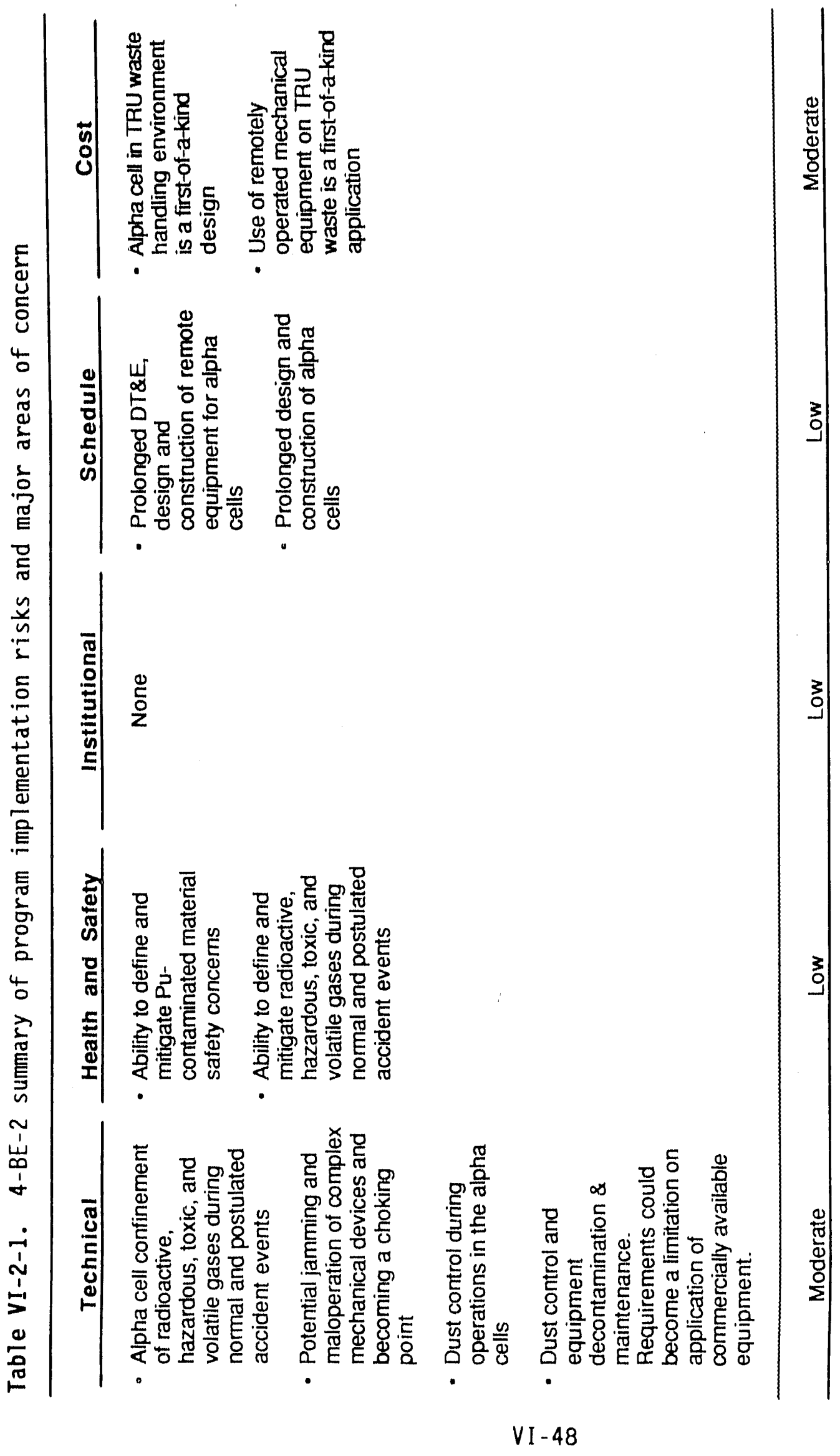


This protection will have to be provided in normal and postulated accident events (e.g., as a fire).

- Using cuimerctal equipment in an alpha cell environment and providing ease of decontamination for maintenance. Several of the waste handling operations will use technologies that are existing, but will have to be adopted for use in an alpha cell environment, which requites remote operation and ease of decontamination for maintenance.

- Potential jamming and maloperation of the complex mechanical components. Also, any of these unit operations could become a potential choke point because of $11 \mathrm{mited}$ prior knowledge of waste streams and the high throughput requirements.

- Large and complex ventilation and filtration systems to control dust during operations in the alpha cells.

- Unreliable oreration of some of the equipment in a dusty environment. Dust control in the alpha cell environment and equipment decontamination requirements before maintenance could become limitations in the use of commercially available equipment. DT\&E efforts could become more extensive than estimated.

Based on the above discussions, it is believed that the overall risk associated with achieving the performance objectives is moderate.

2.2.2.2 Health and Safety Objectives. The key health and safety objectives for the Buried Waste Program are to (a) identify the hazards of the remedial action operation, and (b) provide measures to eliminate, control, or mitigate identified hazards. In this system, the major area of uncertainty is the ability to define postulated accident events (such as fire, criticality, and unforeseen release of toxic/hazardous material) for the alpha cells and provide mitigation measures to satisfy the RCRA, NRC, and DOE requirements. The unit operations associated with opening drums, boxes, and waste bags and 
the decompression of pressurtzed contatners provide urique safety concerns regarding potential for release of toxic, hazardous, and volatile gases.

The health and safety uncertainties are largely due to lack of confidence in the abllity to characterize the incoming waste. DT\&E on characterization could provide a better confidence level. It is believed that using remote handiing equipment and conducting operations inside alpha cells will enhance the mitigation measures for a majority of the normal and postulated events. This approach reduces the risk associated with achieving the health and safety objectives. At this stage of the system modeling, it is belleved that the overall risk is low.

2.2.2.3 Institutional objectives. The key institutional objective is to involve the public, as required by CERCLA and NEPA, in the process of selecting a remedial action for the Buried Waste Program. This system model does not have features that ratse institutional concern. Hence, it is belleved that the risk assoclated with achieving the institutional objectives is low.

2.2.2.4 Schedule objectives. The objective of the buried waste schedule is to reach approval for Title II start by mid-1999. This is based on the assumptions that an ROD will be reached by end of FY 2001. The schedule objectives for completion of the Buried Waste Program remedial action is by FY 2019. The following major uncertainties in achieving these objectives have been identified:

- The alpha cells are relatively complex first-of-a-kind structures and could be subject to prolonged design and construction. However, with advanced planning, uncertainties in achieving schedule objectives could be reduced.

- Prolonged DT\&E, design and construction of remotely operated mechanical equipment for sorting, conveying, size reduction, etc. Application of a majority of this equipment for TRU waste is a 
first-of-a-kind application. Again, advanced planning can reduce uncertainties in achleving schedule objectives.

It is belfeved that there is adequate time to resolve the above uncertainties and achieve the goals within the time frame allowed by the schedule objectives. Accordingly, the schedule risk is belleved to be low.

2.2.2.5 cost objective. Assessment of the cost objective is a qualitative characterization based on the uncertainties involved in defining a reasonably accurate cost estimate for the system. Some of the major uncertainties are presented below:

- The use of alpha cell in the given waste processing environment is a first-of-a-kind design subject to cost overruns from prolonged design development. Major areas of uncertainty are (a) the extent of design features needed for operating in a dusty environment, (b) providing safety for postulated accident events (such as fire, criticality, and unforeseen release of toxic/hazardous material), and (c) satisfying the RCRA, NRC, and DOE requirements. Currently, the limited information avallable on waste characteristics contributes to these uncertainties.

- Use of remotely operated mechanical equipment for container opening, sorting, size reduction, and handling of TRU waste is a first-of-a-kind application. Cost uncertainties are anticipated until design, based on DT\&E, is well into its maturity.

Based on the above discussions, the cost risk is believed to be moderate.

\subsubsection{Unit Operations Pro and Con Analysis}

The following is a pro and con assessment of each unit operation of the Waste Solidification and Packagirig System (4-BE-2). The pros (advantages) and cons (disadvantages) are discussed in light of the overall objectives of the 
Environmental Restoration Program. The compatibility of interfaces and specific areas of weaknesses in the untt operation are addressed.

2.2.3.1 Incoming (Unprocessed) Waste Recetving and Opening. This unit operation receives prepackaged waste from the Retrieval Subsystem (S-BE-4) and prepares the waste for processing.

Advantages are that technologies are we11-known and the unit operation provides inventory storage for waste processing streams to inaintain production lines.

A disadvantage is the potential for contamination if an intact drum or waste container is dropped. Also, uncapping and opening containers may involve potential airborne release of radioactive, toxtc, and volatile gasses to the alpha cell.

2.2.3.2 Sorting (Nonmetal/Metal). The sorting unit operation segregates metals from nonmetals and, where applicable, further sorts by waste type (TRU, LLW, soll, etc.). Advantages of sorting are

- Master/slave manipulators are versatile and can perform most tasks

- Trommels and disc screens are simple, reliable devices for soll separation

- Inductive metal detectors will separate nonmagnetic metals (stainless steel)

- Manuar sorting in c?ove boxes is most versatile

- Power manipulators (e.g., electromechanical manipulators) have high lifting capabilities. 
Disadvartiages are

- Master/slave manipulators may be maintenance items and have relatively limited 1 ifting capacities (10 to 400 lb for standard manipulators; new ones under development should have capacities up to 1500 1b)

- Master/slave manipulators are slow and labor intensive

- Trommel and disc screens require large operating spaces

- Magnetic separators will not work for metals that are not magnetic.

2.2.3.3 Size Reduction. The size reduction unit operation prepares the incoming waste stream by coarse size reduction through shredding or crushing and fine sorting to minimize the amount of soils fed to the molten salt oxidizer.

Advantages are

- A drum crusher can reduce the volume of empty used drums

- Compactors are standard size reduction equipment

- Supercompactors can compress all materials including metal objects

- Cryofracture process reduces both metals and nonmetals to small sizes and does not create dust.

Disadvantages are

- Shredders and crushers may be difficult to decontaminate and may generate dust 
- Cryofracture requires development because there are some materials such as stainless steel where the process does not perform well

- Crushers and shredders are mechanical devices with moving parts that will be difficult to maintain in the alpha cell environment.

2.2.3.4 Sludge Drum Unloading. This unit operation prepares the incoming waste stream for final packaging. The drums containing sludge are opened and repackaged into clean certified containers.

An advantage is the commercial devices are available for drum opening, unloading, and repackaging. The disadvantage is that drum unloading systems are mechanical devices with moving parts that will be difficult to maintain in the alpha cell environment.

2.2.3.5 Solidification. The solidification unit operation receives fines, liquids, and organic waste by-products and combines them using physical or chemical processes to solidify the materials.

Advantages are

- Portland cement is a simple well-known process that is readily available (it works best for inorganic contaminants, but also works with oil and grease)

- Lime-based pozzolanic systems have similar pros as Portland cement and can work better with organics, but not with oils.

Disadvan iages are

- Portland cement and pozzolanic systems are not exceptionally leach resistant [the ratio of waste loading to cement is fairly low (1 to 1)], and these systems are not suitable for some organic compounds 
- Thermoplastic resins require the waste to be dried before solidification, the resin product can be damaged by fire, and organic compounds may vaporize during heating in the solidification process

- Organic polymers are harder to process and costs are about five times more than those for cement

- Portland cement generates dust.

2.2.3.6 Vent Bags. This operation punctures plastic bags to release gas build-up in the bag before shredding the bag content.

One advantage is that a puncturing device will positively vent a plastic bag. However, techniques for sampling gases and vents from the bag are difficult to implement and time-consuming. Also, extreme safety measures are needed to provide protection against release of unforseen toxic gases and liquids.

2.2.3.7 Decompression. The decompression unit operation processes waste gas cylinders by depressurization and volume reducing the empty cylinders.

An advantage is that punching or drilling is a simple operation. The equipment is readily available. A disadvantage is that punching or drilling can create a spark, which can be an ignition source to flammable vapors. Also, extreme safety measures are needed to provide protection against release of unforseen gases and liquids.

2.2.3.8 Assay/Certification. The assay/certification unit operation examines and quantifies the radioactive properties of the filled containers to classify and to ensure compliance with regulations for final disposal.

Advantages are that instruments for certification are available and the unit provides the final check for regulatory compliance. 
Disadvantages are (a) changing WIPP acceptance criteria may change the instruments required, (b) there is a potential for recycle if the filled containers do not meet specifications, and (c) production-scale instrumentation with high throughput and reliability needs development.

\subsubsection{Unit Operations Lead-Time Estimates}

The lead-times required for DT\&E are estimated for each unit operation that may require DT\&E before landing in the field and are shown in Table VI-2-2. The development of the lead-time required for DT\&E is based on a qualitative judgment and should be further defined.

\subsubsection{Rough Order of Magnitude Cost Estimates}

ROM costs were developed for the Sort, Treat, and Repackage System (4-BE-2) using the assumptions given in Section 1. The costs are summarized in Table VI-2-3.

The assumptions and qualifications used in the preparation of the ROM estimate for this system are as follows:

- Special site preparation costs are not included such as drainage, substations, roadwork, and other utilities.

- Owner's costs such as environmental impact report costs, owner's labor, and overheads are not included.

- The estimate is based on first quarter 1991 wage and price levels.

- The facility areas are developed based on the conceptual layout of process equipment. Allowances for administrative and remote operation facilities are not included. 


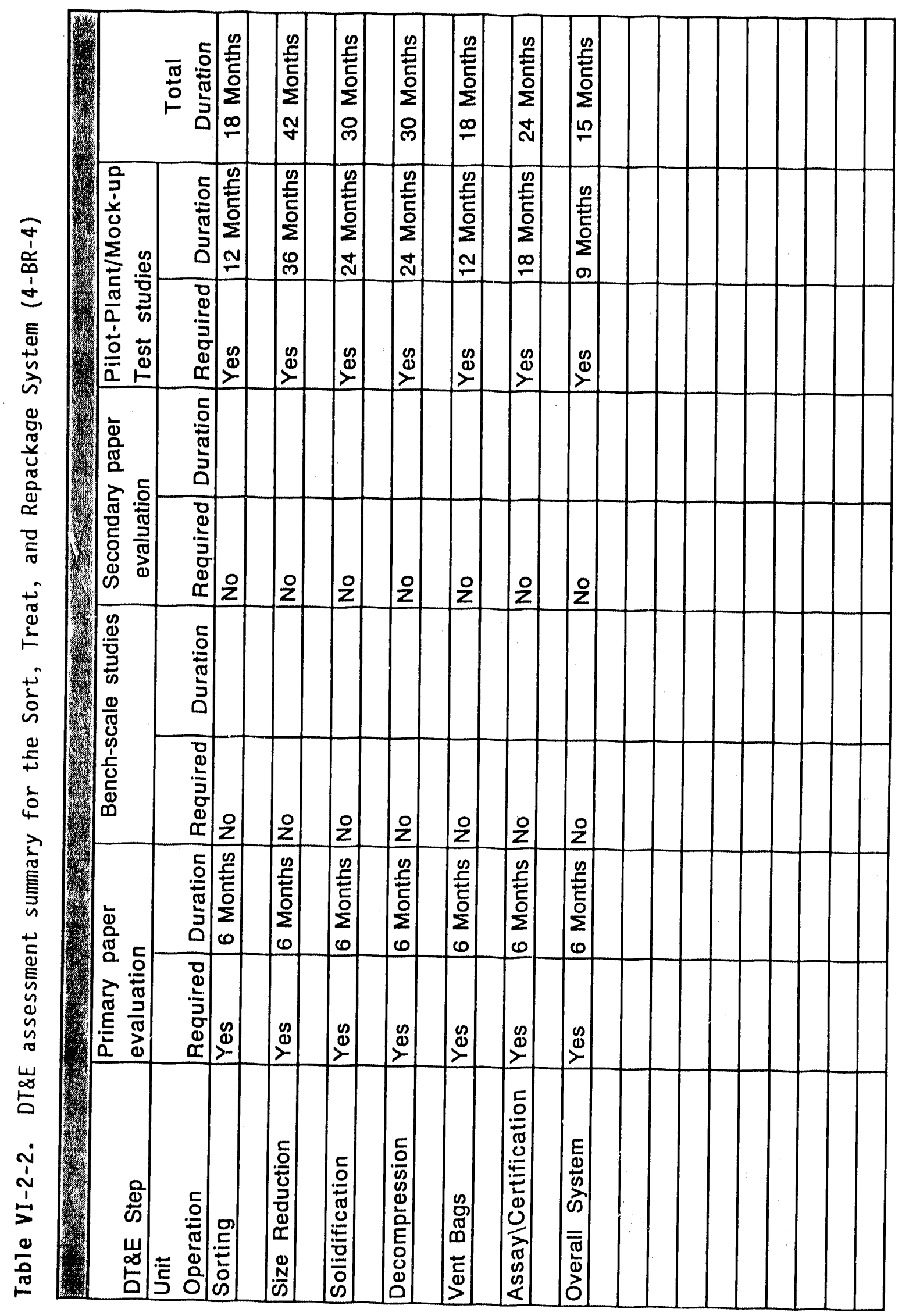


Table VI-2-3. Rough order of magnitude cost estimates $(4-B E-2)^{a}$

\begin{tabular}{|c|c|c|c|}
\hline $\begin{array}{l}\text { Cost } \\
\text { Code } \\
\end{array}$ & Cost Items & $\begin{array}{c}\text { Normallzed } \\
\text { Cost } \\
(\$ \times 1000) \\
\end{array}$ & $\begin{array}{c}\text { Modllied } \\
\text { Cosi } \\
(\$ \times 1000)\end{array}$ \\
\hline 1.0 & Studies and bench scale costs & & \\
\hline 1.1 & Manpower costs during research & $\$ 1,600$ & $\$ 1,600$ \\
\hline 1.2 & Equipment costs & $\$ 1,000$ & $\$ 1,000$ \\
\hline 1.3 & Installatlon costs & $\$ 250$ & $\$ 250$ \\
\hline \multirow[t]{2}{*}{1.4} & Contingency & $\$ 713$ & $\$ 713$ \\
\hline & Subtotal 1.0 & $\$ 3,563$ & $\$ 3,563$ \\
\hline 2.0 & Demonstration costs & & \\
\hline 2.1 & Manpower cost durling construction & $\$ 3,200$ & $\$ 3,200$ \\
\hline 2.2 & Design cost $(30 \%$ of 2.5$)$ & $\$ 2,277$ & $\$ 2,277$ \\
\hline 2.3 & Inspection cost $(7 \%$ of 2.5$)$ & $\$ 531$ & $\$ 531$ \\
\hline 2.4 & Project administration ( $10 \%$ of 2.5 ) & $\$ 759$ & $\$ 759$ \\
\hline 2.5 & Construction cost & & \\
\hline 2.5 .1 & Bullding structure costs & $\$ 1$ & $\$ 1$ \\
\hline 2.5 .2 & Equlpment costs & $\$ 6,000$ & $\$ 6,000$ \\
\hline \multirow[t]{2}{*}{2.5 .3} & Indirect $(20.9 \%$ of 2.5$)$ & $\$ 1,590$ & $\$ 1,590$ \\
\hline & Subtotal of 2.5 & $\$ 7,591$ & $\$ 7,591$ \\
\hline 2.6 & Construction management costs ( $27.8 \%$ of 2.5 ) & $\$ 2,179$ & $\$ 2,179$ \\
\hline \multirow[t]{2}{*}{2.7} & Contingency & $\$ 4,134$ & $\$ 4,134$ \\
\hline & Subtotal 2.0 & $\$ 20,672$ & $\$ 20,672$ \\
\hline 3.0 & Production construction cosis & & \\
\hline 3.1 & Design cost $(30 \%$ of 3.4$)$ & $\$ 64,502$ & $\$ 26,779$ \\
\hline 3.2 & Inspectlon cost $(7 \%$ of 3.4$)$ & $\$ 15,050$ & $\$ 6,249$ \\
\hline 3.3 & Project administration ( $10 \%$ of 3.4 ) & $\$ 21,501$ & $\$ 8,927$ \\
\hline 3.4 & Construction cost & & \\
\hline 3.4 .1 & Bullding structure costs & $\$ 139,337$ & $\$ 39,937$ \\
\hline 3.4 .2 & Equipment costs & $\$ 30,628$ & $\$ 30,628$ \\
\hline \multirow[t]{2}{*}{3.4 .3} & Indirect $(20.9 \%$ of 3.4$)$ & $\$ 45,041$ & $\$ 18,700$ \\
\hline & Subtotal of 3.4 & $\$ 215,006$ & $\$ 89,265$ \\
\hline 3.5 & $\begin{array}{l}\text { Construction management costs and construction management } \\
\text { reserve }(26.5 \% \text { of } 3.4)\end{array}$ & $\$ 61,707$ & $\$ 25,619$ \\
\hline \multirow[t]{3}{*}{3.6} & Contingency ( $25 \%$ of 3.1 through 3.5$)$ & $\$ 94,441$ & $\$ 39,210$ \\
\hline & Subtotal 3.0 & $\$ 472,207$ & $\$ 196,048$ \\
\hline & Total Capltal Cost $(1.0,2.0$, and 3.0$)$ & $\$ 496,442$ & $\$ 220,282$ \\
\hline 4.0 & Annual operating and maintenance costs & & \\
\hline 4.1 & Operating costs & $\$ 30,000$ & $\$ 30,000$ \\
\hline 4.2 & Utility costs & $\$ 7,000$ & $\$ 7,000$ \\
\hline 4.3 & Material costs & $\$ 11,000$ & $\$ 11,000$ \\
\hline 4.4 & Maintenance costs & $\$ 13,000$ & $\$ 13,000$ \\
\hline 4.5 & Contingency & $\$ 15,250$ & $\$ 15,250$ \\
\hline TOTAL & $\begin{array}{l}\text { Subtotal } 4.0 \\
10 \text { Years Operating and Maintenance Cocts }\end{array}$ & $\$ 76,250$ & $\$ 76,250$ \\
\hline & 10 Years Operating and Maintenance Costs & & $\$ 762,500$ \\
\hline
\end{tabular}


- The areas shown in the functional and operational requirement (F\&OR) general arrangement were adjusted to account for the unit operation capacities.

- The equipment scope was based on conceptual process flow diagrams.

- Equipment pricing is based on conventional commercial construction.

- Minimal allowance (e.g., one-of-a-kind demonstration) has been included for remote operation as well as any nuclear quality assurance program cost.

- An allowance for process bulks are included at $30 \%$ of the equipment cost to account for electrical, piping, and local control requirements.

- The cost estimate is based on all technologies with the exception of vitrification and cryofracture, and one-and-a-half years of demonstration (system integration) is assumed.

- The demonstration of the system is assumed to occur within existing facilities.

- Equipment costs include material, fabrication, delivery, inspection, and installation costs (all in costs).

- Costs for widening or strengthening existing roads for construction are not included.

- An adequate supply of labor is assumed to exist within the local area.

- Testing and initial startup costs are not included. 
- Operating and matntenance costs are based on $15 \%$ of production construction costs.

- Cost estimates are based on nominal costs associated with the best currently available technology considered. The lowest technology and the state-of-the-art systems were not considered in the cost mode 1 .

- The cost estimate does not include the cost of the Waste Retrieval, Metal Decontamination and Sizing, or Soils Processing Subsystems.

The cost estimate is based on relatively well-known technologies, but subsystem costs may vary between systems depending on the technologies employed. No provision was made for research and development associated with state-of-the-art technoiogies.

\subsubsection{System Evaluation Results}

The purpose of this section is to provide an overall evaluation of a system basis and to identify the major considerations (both advantages and disadvantages) resulting from the assessments in the previous sections. This includes an evaluation of the ability to integrate the various unit operations into a smooth, well-functioning system.

Specific areas addressed include identification of system major considerations, a qualitative judgment rating of performance measurables, a summary of research and development needs, and a summary of DT\&E needs.

\subsubsection{Identification of System Major Considerations. The techniques} employed in this system, except for cryofracture, are well-known, commercially available, and in current use by industry. The cryofracture process is currently being used, but on a more limited scale than that of other technologies in the system. 
2.2.6.1.1 Risk Assessment--There is a risk associated with the alpha cell enclosure and accessibility to repair or maintain the equipment. It is 1ikely that cryofracture will not perform well with some types of stainless steels. There may be incompatibilities with the waste stream composition and the solidification system. The decompression unit operation may pose safety hazards.

2.2.6.1.2 Pro/Con Assessment-- The significant pro for this system is that the processes employed by the system are all in use and we11-known.

2.2.6.1.3 Schedule--The technologies, except for solidification and cryofracture, do not require significant DT\&E. Demonstration time is requited for integration of all unit operations.

\subsection{Cost Estimate--The costs for this system should be} well-known because the technologies are in current use.

2.2.6.2 Performance Measurables Rating. Performance measurables that should be used in the evaluation of the overall system represent the top level of performance requirements that will be allocated and then applied to appropriate elements of the system in subsequent phases of the program. Table VI-2-4 provides a qualitative assessment of how well the Sort, Treat, and Repackage System satisfies these performance measurables.

\subsubsection{Summary of Demonstration, Testing, and Evaluation Needs}

The DT\&E needs for each unit operation and for the overall system have been summarized in Table VI-2-5. This table provides a ready reference of DT\&E needs in the final system evaluation and for comparison purposes with other systems. 


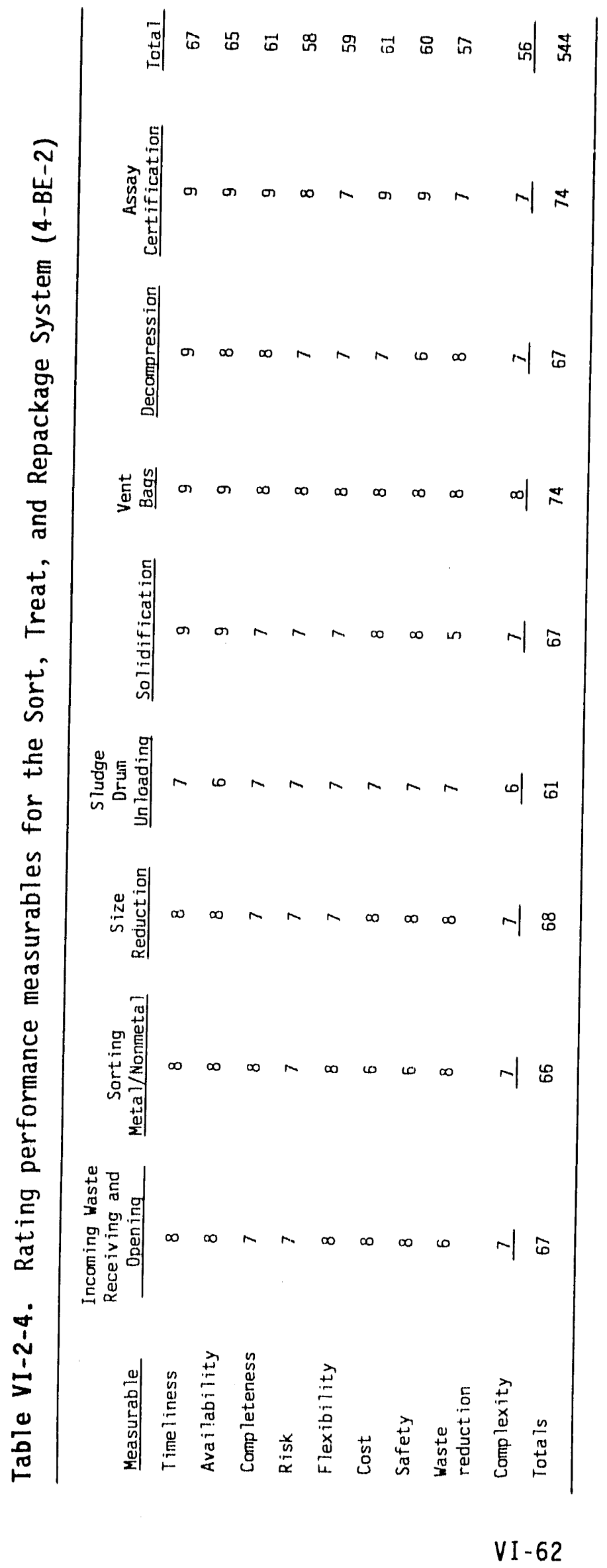


Table VI-2-5. DT\&E needs for the Sort, Treat, and Repackage System (4-BE-2)

\begin{tabular}{|c|c|c|}
\hline $\begin{array}{c}\text { Unit } \\
\text { Operation }\end{array}$ & $\begin{array}{l}\text { Technology } \\
\text { Development } \\
\text { Status } \\
\end{array}$ & DT\&E \\
\hline $\begin{array}{l}\text { Incoming waste-. } \\
\text { receiving and } \\
\text { opening }\end{array}$ & $\begin{array}{l}\text { - Commercially } \\
\text { available } \\
\text { - Currently used } \\
\text { in mining and } \\
\text { metal industry }\end{array}$ & $\begin{array}{l}\text { - Application in production-scale } \\
\text { environment opening } \\
\text { - Integration } \\
\text { - Application to waste stream } \\
\text { - Select technology and/or } \\
\text { equipment based on reltability, } \\
\text { avallability and maintainability } \\
\text { (RAM) } \\
\text { - Select design concepts and } \\
\text { criteria } \\
\text { - Remote operations } \\
\text { - Maintenance concepts (remote or } \\
\text { contact) }\end{array}$ \\
\hline Sorting & $\begin{array}{l}\text { - Commercially } \\
\text { available } \\
\text { - Currently used } \\
\text { in nuclear } \\
\text { industry }\end{array}$ & $\begin{array}{l}\text { - Application in production-scale } \\
\text { environment } \\
\text { - Integration } \\
\text { - Application in alpha cell } \\
\text { - Application to waste stream } \\
\text { - Select technology and/or equipment } \\
\text { based on RAM } \\
\text { - Select design concepts and } \\
\text { criteria } \\
\text { - Remote operations } \\
\text { - Maintenance concepts (remote or } \\
\text { contact) }\end{array}$ \\
\hline
\end{tabular}


Table VI-2-5. (continued)

\begin{tabular}{|c|c|c|}
\hline $\begin{array}{c}\text { Unit } \\
\text { Operation }\end{array}$ & $\begin{array}{l}\text { Technology } \\
\text { Development } \\
\text { Status } \\
\end{array}$ & DT\&E \\
\hline $\begin{array}{l}\text { Size } \\
\text { reduction }\end{array}$ & $\begin{array}{l}\text { - Commercially } \\
\text { avallable } \\
\text { - Currently used } \\
\text { in nuclear } \\
\text { industry }\end{array}$ & $\begin{array}{l}\text { - Application in production-scale } \\
\text { environment } \\
\text { - Integration } \\
\text { - Application in alpha cell } \\
\text { - Application to waste stream } \\
\text { - Select technology and/or equipment } \\
\text { based on RAM } \\
\text { - Select design concepts and } \\
\text { criteria } \\
\text { - Remote operations } \\
\text { - Maintenance concepts (remote or } \\
\text { contact) } \\
\text { - Investigate cryofracture } \\
\text { technology and its application to } \\
\text { SDA }\end{array}$ \\
\hline $\begin{array}{l}\text { Sludge drum } \\
\text { unloading }\end{array}$ & $\begin{array}{l}\text { - Commerclally } \\
\text { avallable } \\
\text { - Currently used } \\
\text { in DOE and } \\
\text { nuclear } \\
\text { industry }\end{array}$ & $\begin{array}{l}\text { - Application in production-scale } \\
\text { environment } \\
\text { - Integration } \\
\text { - Application to alpha cell } \\
\text { - RAM in an alpha cell environment } \\
\text { - System design, operation, and } \\
\text { optimization }\end{array}$ \\
\hline
\end{tabular}


Table VI-2-5. (continued)

\begin{tabular}{|c|c|c|}
\hline $\begin{array}{c}\text { Unit } \\
\text { Operation }\end{array}$ & $\begin{array}{l}\text { Technology } \\
\text { Development } \\
\text { Status }\end{array}$ & DT\&E \\
\hline Solidification & $\begin{array}{l}\text { - Commerclally } \\
\text { avallable } \\
\text { - Currently used } \\
\text { in DOE and } \\
\text { nuclear } \\
\text { factlities }\end{array}$ & $\begin{array}{l}\text { - Integration of process in } \\
\text { production-scale environment } \\
\text { - RAM of prototype equipment } \\
\text { - Select the process compatible with } \\
\text { waste stream and product } \\
\text { regulatory requirements } \\
\text { - Select technology and/or equipment } \\
\text { based on RAM } \\
\text { - Select design concepts and } \\
\text { criterta } \\
\text { - Remote operation } \\
\text { - Maintenance concepts (remote or } \\
\text { contact) }\end{array}$ \\
\hline Vent bags & $\begin{array}{l}\text { - Commerctally } \\
\text { avatlable }\end{array}$ & $\begin{array}{l}\text { - Application in production- } \\
\text { scale environment } \\
\text { - Integration } \\
\text { - Application in alpha cell } \\
\text { - Optimization to a wide range of } \\
\text { influents } \\
\text { - RAM in an alpha cell environment } \\
\text { - Select technology and equipment } \\
\text { - Characterization of off-gas stream } \\
\text { - Identify recovery methods of off- } \\
\text { gas contaminants } \\
\text { - Identify cleanup efficiency } \\
\text { decontamination factor } \\
\text { requirements }\end{array}$ \\
\hline
\end{tabular}


Table VI-2-5. (continued)

\begin{tabular}{|c|c|c|}
\hline $\begin{array}{c}\text { Unit } \\
\text { Operation }\end{array}$ & $\begin{array}{l}\text { Technology } \\
\text { Development } \\
\text { Status } \\
\end{array}$ & DT\&E \\
\hline Decompression & $\begin{array}{l}\text { - Commerctally } \\
\text { avatlable } \\
\text { - Currently used } \\
\text { in manufac- } \\
\text { turing } \\
\text { industry }\end{array}$ & $\begin{array}{l}\text { - Application in production-scale } \\
\text { environment } \\
\text { - Integration } \\
\text { - Application in alpha cell } \\
\text { - RAM in an alpha cell environment } \\
\text { - Select technology and equipment } \\
\text { - Characterization of released gases } \\
\text { - Integration } \\
\text { - Identify cleanup efficiency } \\
\text { decontamination factor } \\
\text { requirements }\end{array}$ \\
\hline $\begin{array}{l}\text { Assay/ } \\
\text { certification }\end{array}$ & $\begin{array}{l}\text { - Commercially } \\
\text { available }\end{array}$ & $\begin{array}{l}\text { - Application to current } \\
\text { transportation and disposal } \\
\text { requirements }\end{array}$ \\
\hline w. & $\begin{array}{l}\text { - Currently used } \\
\text { in DOE and } \\
\text { nuclear } \\
\text { facilities }\end{array}$ & $\begin{array}{l}\text { - RAM of prototype equipment } \\
\text { - Automation } \\
\text { - Integration of process in } \\
\text { production-scale environment }\end{array}$ \\
\hline Overall system & & $\begin{array}{l}\text { - Application in production-scale } \\
\text { environment } \\
\text { - Integration of entire process } \\
\text { - RAM of process in an alpha cell } \\
\text { environment } \\
\text { - Remote operation and maintenance } \\
\text { - Automation }\end{array}$ \\
\hline
\end{tabular}




\subsection{Recommendation for the System}

The Sort, Treat, and Package System essentially uses existing technology to collect, sort, size-reduce, solidify, and package the retrieved waste to meet current burial standards. There is no physical conversion of the input streams except for the solidification process. The technologies employed are all currently available, permitting an early start on design, fabrication, and installation. It appears that much of the RWMC waste could be processed with these technologies today. However, the system does not use volume reduction concepts and is based on minimal processing philosophy.

Several issues that will require further DT\&E include (a) analyzing of the queuing of the waste stream to determine capacities of components for unit operations, (b) fine-tuning of all the selected technologies to produce the desired end results, (c) reviewing the integration of the process streams to ensure compatibility, (d) considering on-line sensors that monitor and report status and progress of waste stream processing, and (e) evaluating, in detail, the treatment of gases generated during bag opening.

This study helped to characterize and define a number of alternatives for the unit operations of this system. The evaluations conducted under this study conclude that DT\&E is required. Qualitative judgments were used in developing the extent of DT\&E required. A more detailed assessment is needed to draw a definitive conclusion on DT\&E programs and technology selection.

Risk assessments in the study are qualitative and judgmental and are based on the assumption that wastes having dangerous physical or chemical characteristics (e.g., pyrophoric and gas cylinders containing toxic, flammable, and reactive gases) are not being processed. A more detailed definition of the incoming waste will be needed to perform a complete risk assessment, and significant changes in the composition of the waste may impact the technology selected and the general arrangement of the facilities.

The Sort, Treat, and Repackage System offers the approach if processing and packaging the waste for direct burial with minimal processing and very little volume reduction. 
VI -68

1 


\section{VOLUME REDUCTION AND REPACKAGE SYSTEM (4-BE-4)}

This document contains F\&ORs for the Waste Volume Reduction and Packaging system. The system, S-BE-4, includes all facilities, processes, equipment, and ancillary components required for the retrieval, processing, and packaging of the TRU waste buried at RWMC. The system converts the incoming waste into a physical and chemical form that has reduced hydrogen generation potential and meets the WIPP WAC and TRAMPAC-II transportation package requirements.

\subsection{Functional and Operational Requirements}

\subsubsection{System Description}

The Volume Reduction and Package System (4-BE-4) is comprised of four subsystems and several unit operations and includes the Retrieval subsystem (S-BE-4); Soils Processing Subsystem (S-EB-2); Metal Decontamination and Sizing Subsystem (S-BE-1); and the Receiving, Processing, and Packaging Facility.

The Retrieval Subsystem provides all the necessary processes and unit operations to retrieve and gross sort the buried waste. The Retrieval Subsystem and its related unit operations are described in Volume VII. Peripheral soil, bulk metal, loose material, and intact containers comprise the four major output streams from the Retrieval Subsystem.

The peripheral soil output is transported via reusable containers to the Soils Processing Subsystem (S-EB-2). This subsystem has all the facilities and eyuipment needed for treatment and disposal of the contaminated soil. The Soils Processing Subsystem and its related unit operations are described in Volume VII.

The bulk metal output is containerized and transported to the Metal Decontamination and Sizing Subsystem (S-BE-1). This subsystem has all the facilities and equipment needed for treatment of the metal to reduce hydrogen 
generation potential. The Metal Decontamination and Sizing Subsystem and its related unit operations are described in Volume VII.

Loose material and intact containers (including gas cylinders) are transported to the Waste Receiving, Processing, and Packaging Facility. At this facility, the containers are opened, and the waste is removed and processed through a sorting unit. The sorting unit segregates the waste into metal and nonmetal (includes gas cylinders) streams. The metal waste stream is sent to the Metal Decontamination and Sizing Subsystem. The nonmetal stream is further sorted as LLW and TRU waste.

The LLW stream is fed to the Low-Level Waste Processing Subsystem. This subsystem has all the facilities and equipment needed for the treatment and disposal of $L L W$. The $L L W$ processing facility and the related unit operations are described in Volume VII.

The TRU waste stream from the second sorting unit is sent to a third sorting unit. This unit segregates the incoming waste stream into noncombustibles and combustibles, compressed gas cylinders, inorganic sludge, organic sludge, liquid waste, and plastic bag categories. Each of the five waste streams are treated by various unit operations according to the specific WIPP WAC and TRAMPAC-II waste form compliance requirements.

Noncombustibles and combustibles are volume-reduced and loaded into containers. Compressed gas cylinders are decompressed, size-reduced, processed for volume reduction, and loaded into containers. Inorganic sludge is loaded directly into containers. The plastic bags are punctured and processed for volume reduction and placed into containers.

The organic sludge, plastic bags, soil, and liquid waste stream are incinerated. The incineration product is discharged to a solidification unit. The incineration secondary combustion waste stream includes gaseous and liquid waste streams. The gaseous waste stream is treated in an off-gas unit operation and discharged to the atmosphere. The liquid stream is sent to the solidification unit operation. 
The incineration products and the liquid waste are solidified in containers. Each packaged waste container is processed through a radio-assay and a final certification process. Certified containers are sent to an interim storage facility. Shipment of the containers is performed by removing the containers from the interim storage area and loading the containers into transportation over-packs. Over-packs, mounted on shipping vehicles, are used for offsite shipment and disposal.

A description of the unit operations in the Waste Receiving, Processing, and Packaging Facility is presented below:

- Incoming (unprocessed) waste receiving and opening:

- Unit operation summary: The receiving portion of the Waste Receiving, Processing, and Packaging Facility processes the incoming waste from the Retrieval Subsystem. These processes include unloading the incoming vehicles; providing surge storage of the waste contained in reusable containers; unloading the reusable containers; and uncapping, opening, and dumping the waste contained in the intact containers.

- Reusable containers: The retrieved waste, including loose material and intact containers, will be placed in reusable containers designed for onsite transportation.

- Onsite transportation vehicle: An onsite transportation vehicle will be used to ship the reusable containers from the Retrieval Subsystem (see Volume VII) to the Waste Receiving, Processing, and Packaging Facility.

Receiving, unloading, and surge storage: At the Waste Receiving, Processing, and Packaging Facility, the reusable containers will be unloaded from the incoming vehicles and placed in an interim storage area. 
- Unloading of reusable containers: Reusable containers will be taken out of the storage area to the container opening and unloading subsystem. This subsystem removes the reusable container caps and empties the contents of the container.

- Instefum unloading: A drum unloading device will remove the intact drunis caps and feed its contents to the sorting unit. Waste containers containing organic and inorganic sludge will be taken directly to the container handling station.

- Reusable container decontamination: The empty reusable containers will be decontaminated, inspected, and sent back to the Retrieval Subsystem.

- Sorting (non-metal/metal):

- Unit operation summary: The sorting unit operation includes all facilities, supporting subsystems, and equipment that will be needed to sort metal objects from the incoming waste stream.

Coarse sorting: Loose material and contents removed from the intact drums are conveyed to a sorting table (various sorting technologies such as vibratory tables and air classifiers may be used). The device will remove and separate out bulk metallic objects from the incoming waste stream. The bulk metallic objects will be fed to the Metal Decontamination and sizing Subsystem. The remaining loose material and gas cylinders will be processed through a fine sorting device.

Fine sorting: The first sorting device will contain a separator to remove any remaining metal from the waste stream (various technologies such as magnetic separation devices may be used). The metal contents will be diverted to waste containers and transferred to the Metal Decontamination and sizing Subsystem. The nonmetallic waste, primarily loose 
material, will be sent to the LLW/TRU unit operation. Gas cylinders will be sent to the decompression unit operation.

- $\quad$ Sorting (LLW/TRU):

- Unit operation summary: The LLW/TRU sorting unit operation includes all facilities, subsystems, and equipment needed to determine radioactivity and physical properties. If the parameters needed to classify and certify the waste package are also in compliance with the transportation and disposal regulations, this unit operation separates LLW waste from TRU waste.

- Radio-assay: The waste stream will be examined by radio-assay devices to allow classification of waste in accordance with DOT, DOE, and NRC transportation and disposal requirements. Containers will also be weighed. Various devices, such as PAN, SGS instruments, and load cells, may be used. The radio-assayed containers will first be classified either as LLW or TRU waste. LIW containers will be transported to the LowLevel Waste Subsystem (S-IT-3). Containers classified as TRU will be transported to the waste sorting unit operations.

- Fine waste sorting: The third sorting device will segregate the waste into five streams. Various technologies, such as air classification and screening, may be used. Organic sludge, liquid waste, and plastic bags will be collected and sent to the VOC treatment unit operation. Combustibles and noncumbustibles will be removed and sent to the volume reduction unit operation. Compressed gas cylinders will be removed and transferred to the decompression unit operation. Inorganic sludge will be collected and sent to the container handling station. 
- Volume reduction:

- Unit operation summary: The volume reduction unit operation includes all facilities, subsystems, and equipment needed to convey the waste from the sorting unit operation, uncap and empty drums containing loose materials, and reduce the volume of the incoming waste to facilitate filling containers and storing.

- Volume reduction device: Incoming waste streams from the sorting unit and waste containers containing combustibles, noncombustibles, and compressed gas cylinders will be dumped into a volume reduction unit (e.g., compactor, shredder, or slow speed crusher). The reduced waste will be transferred to the container handling station.

- Filled container handling: Incoming waste will be loaded into containers, capped, smear tested to determine surface contamination, and washed down if necessary. The containers will then be sent to the assay/certification station. The liquid waste from the container wash down operation will be discharged into the flush water storage tanks.

Sludge drum unloading: A drum unloading device will remove the sludge drum cap and feed its contents to the size reduction unit.

Filled container handling: Incoming waste will be loaded into containers, capped, smear tested to determine surface contamination, and washed down if needed. The containers will then be sent to the assay/certification station. The liquid waste from the container wash down operation will be discharged into the flush water storage tanks. 
- Decompression:

- Unit operation summary: The decompression unit operation includes all facilities, subsystems, and equipment needed to convey the waste from the sorting unit operation, uncap and empty drums containing compressed gas cylinders, shear the incoming waste in a vented chamber to capture released gases, and convey the waste to the volume reduction unit.

- Decompression device: Incoming waste streams from the sorting unit and waste containers containing compressed gas cylinders will be placed into a vented chamber and punctured or sheared to release the compressed gases. The waste will be transferred to the volume reduction station.

- Drum unloading: A drum unloading device will remove drum caps and feed its contents to the decompression unit.

- Thermal decomposition:

- Unit operation summary: The thermal decomposition unit operation includes all facilities, subsystems, and equipment needed to convey the waste from the sorting unit to the thermal decomposition subsystem, store heat and feed fuel to the incinerator and secondary combustion chamber, feed waste into the incinerator collect, store and feed the incinerated product to the solidification unit, and collect and transfer gaseous waste to the off-gas treatment unit operation.

- Fuel oil storage: Fuel ofl will provide heat to the incinerator and secondary combustion chamber. The fuel storage tanks will receive fuel from bulk shipping vehicles.

- Incinerator: The incinerator will receive waste and soil from the sorting unit. Fuel $0 i 1$ and combustion air will provide 
heat to the refractory-lined rotary $k+1 n$. The incinerator will be operated at an oxygen defictent atmosphere to promote pyrolysis of the combustible material. Noncombustibles and soll will remain with the ash. Incinerator gases will pass into the secondary combustion chamber.

- Secondary combustion chamber: The gaseous pyrolysis products will go to the second combustion chamber operating at $1800^{\circ} \mathrm{F}$, where additional air and fuel are fed to complete oxidation of combustible gases and destruction of hazardous chemicals. The off-gas will go to the off-gas treatment unit operation.

- Product collection and feed: The resultant soil and ash will drop from the incinerator and secondary combustion chamber. The soil and ash mixture will be washed to cool the solids. The remaining soll and ash, which contain the radionuclides from the waste material, will be transferred to the solidification area.

- Off-gas treatment:

- Unit operation summary: The off-gas treatment unit operation includes all facilities, subsystems, and equipment needed to transfer gaseous waste from the secondary combustion chamber discharge point to the treatment unit, which treats gaseous waste to remove particulates and moisture, collects and transfers solids from the dryer to the solidification unit, and samples and measures gas radialion concentration before discharge to ensure compliance with the discharge criteria. The off-gas consists primarily of air, carbon dioxide, and water vapor.

- Dryers/condensers: The off-gas willl pass through a rough moisture separation step and then through condensers before it 
is sent to the HEPA filters. The condensed liquid will be sent to the solidification unit operation.

- Filtration: The non-condensible off-gas passes through HEPA filters before release to atmosphere.

- Sampling and monitoring: The clean off-gas will be sampled before being discharged to the atmosphere. A radiation monitoring device will measure the concentration of the radionuclides in the sample.

- Solidification:

- Unit operation summary: The solidification unit operation includes all facilities, subsystems, and equipment needed to (a) receive and store concentrated liquid waste, fines, and VOC waste, (b) receive and store bulk shipment solidification agents, (c) inject solidification agent and waste into a mixing device, (d) inject the mixture into waste containers, (e) cap the filled waste containers, ( $f$ ) allow curing of the containers filled with solidified waste, (g) smear test the container surface to determine contamination, and ( $h$ ) if necessary, decontaminaie the container to remove surface contamination, transfer the filled containers to radio-assay and certification station, and collect and treat flush water generated during system flush and decontamination operations.

- Waste receiving: The incoming concentrate liquid waste, fines, and VOC waste will be transferred by pumps to the receiving tanks and silos.

- Solidification storage and feed: The agent used for solidification can be either cement, polymer, or bitumen. The solidification agent storage and feed unit will receive agent from bulk shipping vehicles, provide a three-month storage 
capacity for the bulk material, provide a seven-day operation capactty day tank, and provide agent transfer and feed devices. The solidification agent will be metered into the mixing device.

- Mixer: The waste will be mixed with the solidification agent. The mixture will be poured or injected into containers, and will include features for flushing. The flush water will be collected in tanks and treated for reuse. Concentrated sludge will be solidified.

- Filled container handling: Filled containers will first be set aside for a curing perlod (24-48 hours). The containers will then be capped, smear tested to determine surface contamination, washed down if necessary, and sent to the assay/certiffcation station. The liquid waste from the container washdown operation will be discharged into the flush water storage tanks.

- Assay/certification:

- Unit operation summary: The assay/certification unit operation includes all facilities, subsystems, and equipment needed to determine (a) radioactivity, (b) physical properties, and (c) parameters to classify and certify the waste package in compliance with the transportation and disposal regulations and to provide interim storage for the packaged waste.

- Radio-assay: Packaged waste (i.e., filled waste containers meeting the ultimate waste form requirements) will be examined by radio-assay devices to allow classification of waste in accordance with the DOT, DOE, and NRC transportation and disposal requirements. Containers will also be weighed. Various devices such as PAN, SGS instruments, and load cells may be used. Data from the examination will be logged and 
recorded for each container. The radio-assayed containers will first be classifted etther as LLW or TRU waste. LLW contatners will be further classified according to the DOT and NRC requirements and transported to a labeling and $L L W$ certification station. At this station, they will be examined for compliance with shipping and LLW disposal site requirements. Containers classified as TRU will be transported to the TRU certification area.

- Certification: As a mintmum, each LLW and TRU container will be examined by a nondestructive examination and nondestructive assay by a real-time radiography (RTR) device. The containers will also be smear tested again to determine the extent of any exterior contamilation. If the drums are contaminated, a water decontamination process will remove surface contamination. The clean containers will be transferred to an interim storage area.

- Interim storage: The system will have a six-month capacity for the storage of TRU and LLW packaged and certified waste containers (i.e., filled waste containers meeting the ultimate waste form requitrements).

- Shipping: The certified waste packages will be transferred from the storage area to the loading station. At this station, they will be loaded into shipping over-packs, mounted on transportation vehicles, and shipped to the uitimate disposal site.

\subsubsection{System Boundaries}

3.1.2.1 Subsystems. The Volume Reduction and Package System (4-BE-4) includes the Retrieval Subsystem (S-BE-4), Metal Decontamination and Sizing Subsystem (S-BE-1), Sol1s Processing Subsystem (S-EB-2), and Low-Level Waste Subsystem (S-IT-3). 
The physical boundartes for the above subsystems are shown in their respective F\&OR sections. The boundaries for other unit operations of the Waste Volume Reduction and Packaging System are given below.

\subsubsection{Waste Recelving, Processing, and Packaging Facility.}

- Phystcal boundartes: The physical boundaries inciude the Waste Recetving, Processing, and Packaging Factlity that is located in a 5-acre site. The factlity boundary is at the site perimeter fence; butlding foundations, including preparation of the site, the loading dock that is the boundary for the input waste streams, and the shipping dock are the boundaries for the output streams from the facility. This dock packages L.LW and TRU waste shipments to disposal facilities, while nonradioactive solid waste shipments are sent to municipal disposal facllities, and nonradioactive chemical hazardous waste is sent to offsite chemical disposal facilities.

- Utflities: The Waste Recelving, Processing, and Packaging Facility will require services from the service water system and electrical power supply. The system boundaries with the utflittes have service water shut-off valves located at the site fence and 4-kV power supply poles located at the fence. other utilities such as service atr, steam, fuel, and emergency power are a part of the Waste Receiving, Processing, and Packaging Facility.

- Environment: The Waste Receiving, Processing, and Packaging Facility will have a building ventilation system, treated 1 quild waste evaporation pond, and a sanitary drain field. These are physical interfacings with the environment.

\subsubsection{Process Functional Diagram}

Several system-specific assumptions have been made to include the following: 
- The waste volume increases by $10 \%$ during packaging

- The solidification process increases the volume by a factor of two

- The waste volume is decreased by a factor of two during size reduction

- The TRU content from the LLW processing subsystem is within acceptable limits for LLW disposal

- Six-month storage capacity for the packaged waste will be available.

The mass flow rates and energy requirements for the Volume Reduction and Package System are shown in Figure VI-3-1.

\subsubsection{Facility Description}

General arrangements for the Waste Receiving, Processing, and Packaging Facility are shown in Figure VI-3-2.

Storage capacity will be provided for the incoming reusable containers and the final packaged containers. The storage area contains a material handling system, fire protection, and ventilation and monitoring per RCRA.

\subsubsection{System Design Requirements}

3.1.5.1 Functional Requirements. The Volume Reduction and Package System should meet the following functional requirements:

- $\quad$ System retrieves buried TRU waste and peripheral soil from RWMC

- The TRU waste and peripheral soil is classified, sorted, and processed within the facility 
VI -82 


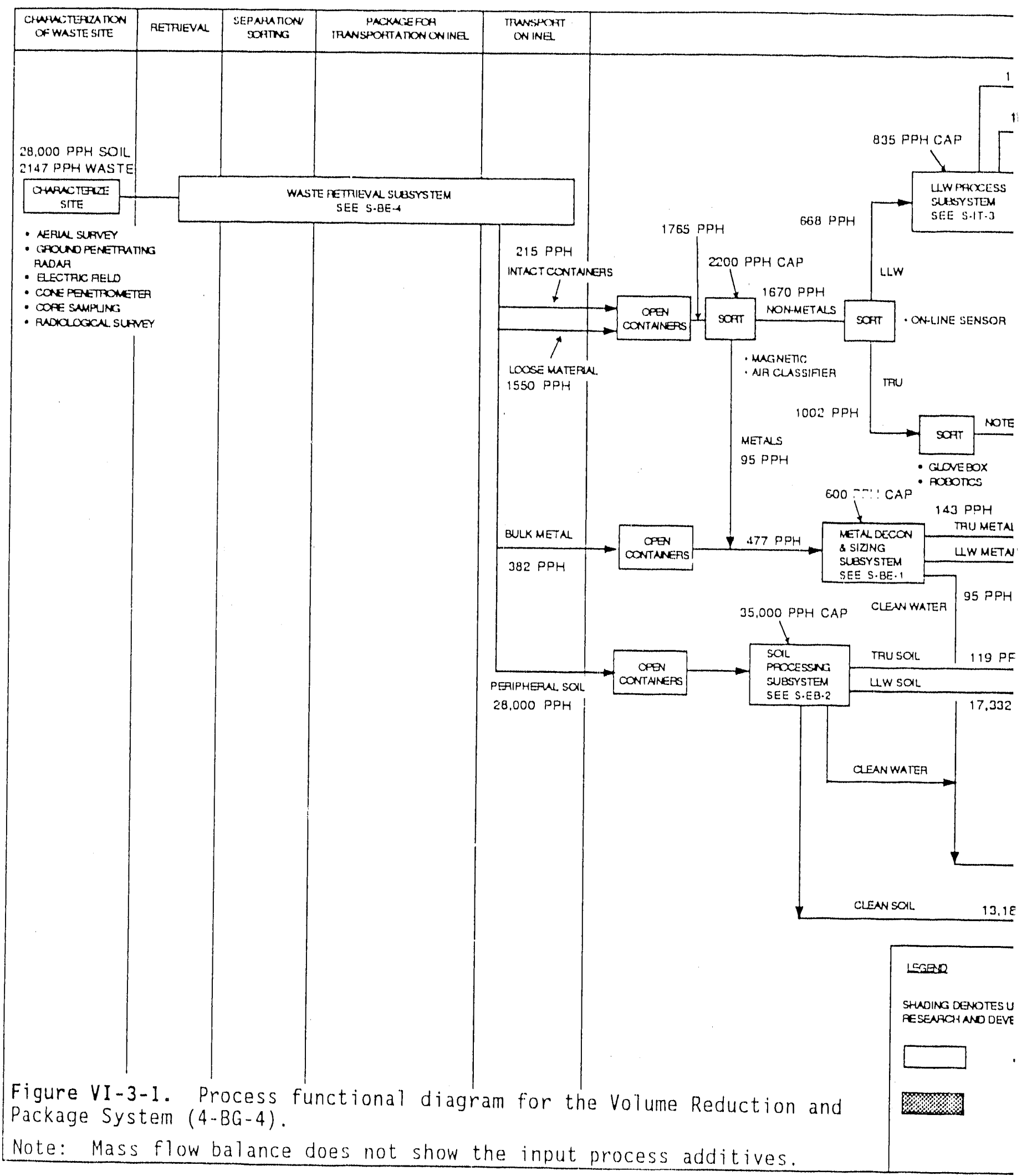




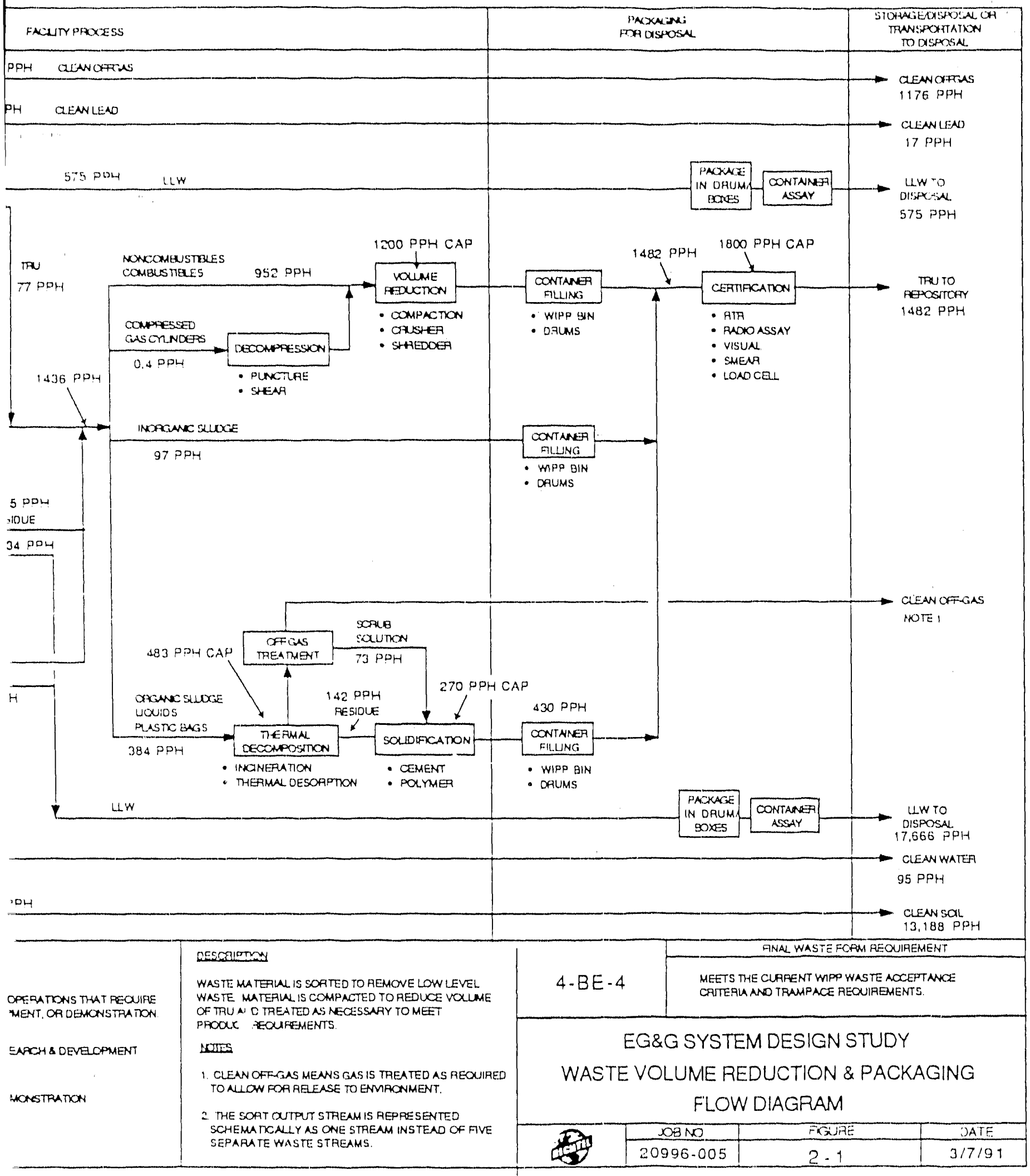


VI -84

هب 


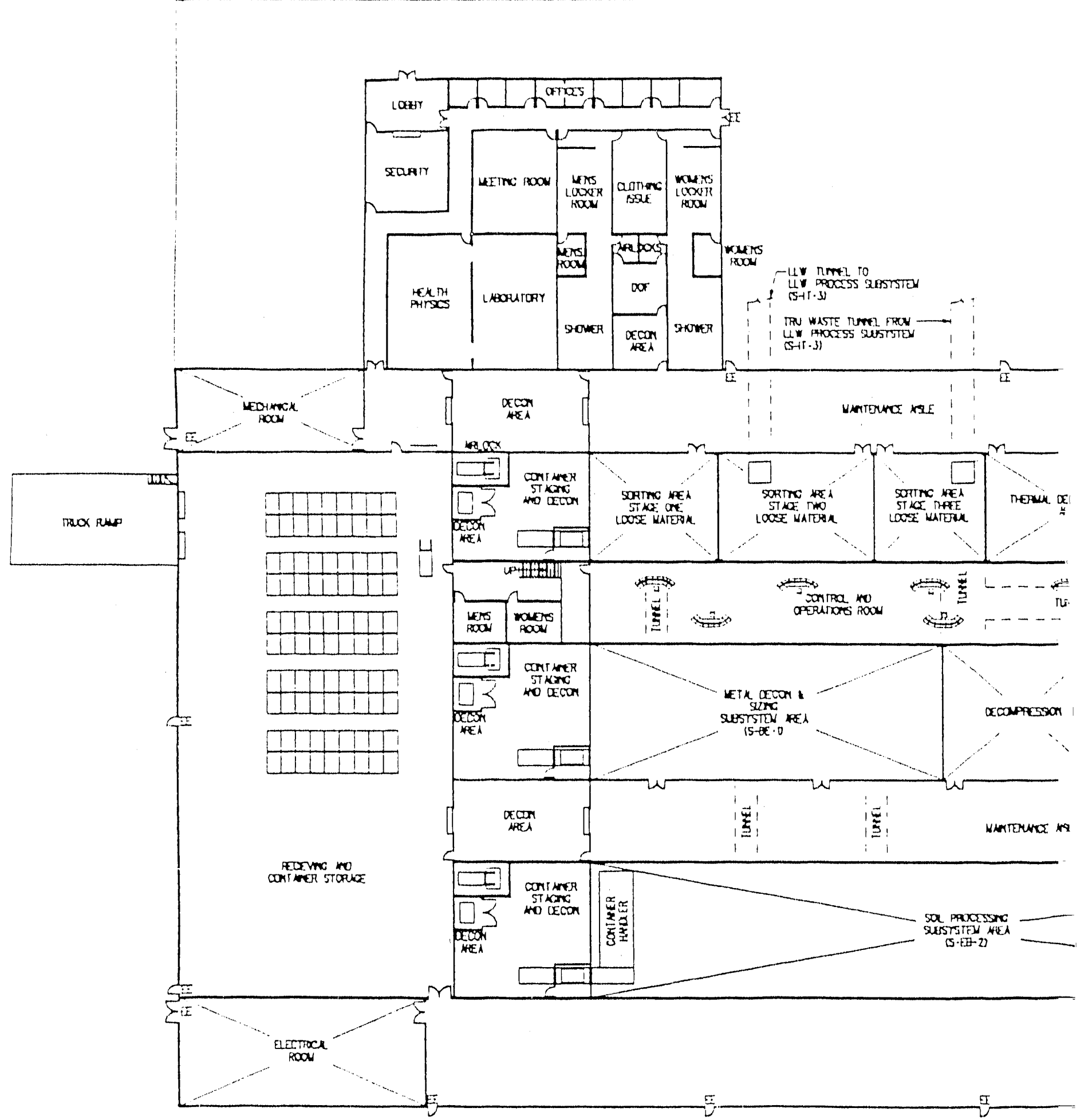

Figure VI-3-2. General arrangements for the Waste Receiving, Processing, and packaging $F$ 

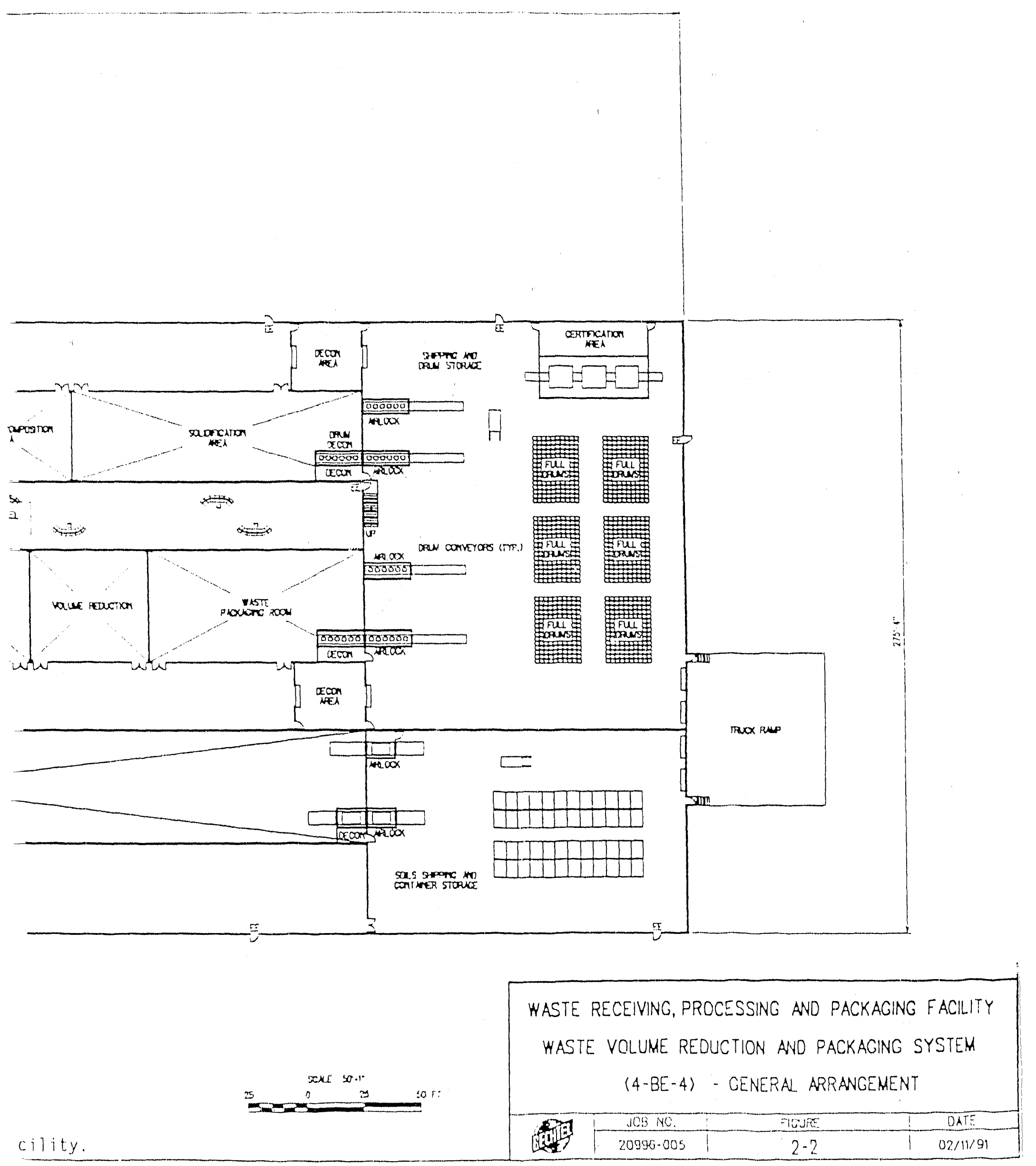

cility. 
- The peripheral soil is treated for compliance with the LDR requirements

- The TRU waste is converted to a form that meets the WIPP WAC and TRAMPAC-II requitrements.

3.1.5.2 Performance Requirements. The Volume Reduction and Package System will meet the following performance requirements:

- The system capacity will be designed to process and package buried waste from RWMC over a ten-year period

- Operational availability of 24 hours/day, 5 days/week, and $70 \%$ plant availability during operation, operating 240 days/year

- Packaged TRU waste will meet the WIPP WAC and TRAMPAC-II requirements

- The system will have the ability to sort and segregate LLW and TRU waste containers

- The system will have the ability to separate metal objects from the waste stream

- The system will minimize the volume of the waste as much as possible

- Impact of the system operation on the environment will be minimal

- The system will be licensable

- The effect of the system operation on the worker and public health and safety will be minimal

- The system will have high reliability, operability, and maintainability factors 
- The system will have the capability to receive different waste types having a diverse set of characteristics

- The system will have the ability to incinerate and solidify fines, liquid waste, and VOC waste.

\subsubsection{Interface Requirements}

The F\&OR sections for the Retrieval (S-BE-4), Metal Decontamination and Sizing (S-EG-1), Soils Processing (S-EB-2), and Low-level Waste (S-IT-3) Subsystems identify the interface requirements for these subsystems. The following interface requirements are those of the other unit operations of the Volume Reduction and Package System. The flow rate values for the input, output, and intermediate points are given in the process functional diagram, Figure VI-3-1.

3.1.6.1 Support to Other Systems (Output). The Waste Receiving, Processing, and Packaging Facility provides output for LLW disposal, the LowLevel Waste Processing Subsystem, the Metal Decontamination and Sizing Subsystem, TRU geological repository, clean soil, exhaust gases from the stacks, treated water, and sanitary waste.

3.1.6.2 Support From Other Systems (Input). The Waste Receiving, Processing, and Packaging Facility receives input from the following:

- Retrieval Subsystem (S-BE-4)

- Soil

- Waste

... Soils Processing Subsystem (S-EB-2)

$-\quad$ TRU 
$-\quad L L W$

- Clean soil

- Metal Decontamination and Sizing Subsystem (S-BE-1)

- TRU

$-\quad L L W$

- Low-Level Waste Subsystem (S-IT-3)

- TRU

$-\quad L L W$

- Utilities

- Fuel oil

- Service water

- Power

- Ventilation input

- Steam

- Consumables

- Solidification materials

- Packaging materials

- Shipping containers both disposable and reusable

VI -89 
- Caustic for aqueous spray drying.

\subsection{System Assessment}

The current status, program implementation risks, and a pro/con analys is of the unit operations associated with the Volume Reduction and Packaging system are discussed below. The integration aspects of forming a complete system that satisfies the functional, performance, and interface requirements are complex and may perturb individual unit operations or necessitate DT\&E and development efforts from integration problems not previously identified.

\subsubsection{Current Status of Unit Operations}

There are 11 unique unit operations associated with the Volume Reduction and Packaging system (4-BE-2). The unit operations are discussed below.

3.2.1.1 Incoming (Unprocessed) Waste Receiving and Opening. This unit operation receives prepackaged waste from the Retrieval Subsystem (S-BE-4) and integrates subsystems and unit operations of the overall system based on assay and segregation of the waste stream. The functions of this unit operation include opening the prepackaged containers (reusable); sorting and segregating waste to put into appropriate unit operations; inventorying storage and accountability; and uncapping, opening, and dumping waste. Incoming containers will be uncapped and opened in an alpha cell environment that has the capability to control dust, drum gas vents, and other hazardous airborne gases and liquids that may leak out of the containers.

The unit operation will typically consist of a loading dock, shielded and enclosed workspace, gantry cranes, manipulater systems, drum/container handling systems (repackaging, uncapping, and recapping), and radiological survey instrumentation. Additional automated process components may include an automated bar coding system for accountability and tracking purposes; information management systems for data retrieval, storage, and processing; and material controls that will monitor and quantify output waste streams. 
Special hoods, dust collection devices, vents, and filters will be provided. Design features will also be provided to collect any potential free liquid that may leak out of the drums and boxes.

These techniques are well-known. The technologies employed in this unit operation are similar to existing material handling and inventory systems currently commercially available. Research is not required. The integration of automated systems within a controlled environment may require demonstration. Considerations of reliability, maintainability, and error recovery operations are paramount in the design.

3.2.1.2 Sorting (Nonmetal/Metal). The sorting unit oporation is designed to segregate metals from nonmetals and, where applicable, to further sort by waste type (TRU, LLW, etc.). There is a wide range of technologies and equipment available. These range from simple manual sorting techniques to sophisticated neutron radingraphy and $x$-ray fluorescence sorting techniques. The equipment that may be employed in the sorting process may include manipulators, screen sieves, manual sort (glove boxes), magnetic detection/separation equiprent, inductive coil metal detectors, and robotics. On-line radiation detection/assay units and on-line hazardous gas detectors/analyzers may also be used.

These techniques are we11-known. The equipment envisioned for this unit operation is commercially available. The integration of the equipment in a controlled environment with appropriate redundancy and error recovery capabilities may require demonstration. Demonstration may also be required for assay equipment with high throughput and for sorting large volumes of waste.

3.2.1.3 Volume Reduction. This unit operation prepares the incoming waste stream for final packaging. The preparation steps include coarse size reduction through shredding or crushing and fine sorting to maximize efficiency in the filling operation. The equipment employed in this unit operation includes drum handling and uncapping systems, a shredder and slow speed crusher, a compactor and super compactor, and cryofracture. 
These techiliques are well-known, commercially available, and in use by industry. The equipment used in this unit operation is standard commercial equipment and will not require research and development beyond its current state. Demonstration may be required to integrate the equipment within an alpha cell enclosure.

3.2.1.4 Sludge Drum Unloading. This unit operation prepares the incoming waste stream for final packaging. The drums containing sludge (without free liquid) are sampled, opened, and repackaged into clean certified containers. The equipment used in this process includes drum handling and unloading equipment, certified container loading and packaging, conveyor systems, and slurry transfer systems.

These techniques are well-known, commercially available, and in use by industry. The equipment used in this unit operation is standard commercial equipment and will not require DT\&E beyond its current state.

3.2.1.5 Decompression. The decompression unit operation is intended to depressurize and shred or otherwise volume reduce compressed gas cylinders. A wide range of technologies may be employed to process the gas cylinders. These include cryogenics, a crusher/shearer, a slow speed shredder, plasma torch cutting, electrical discharge cutting, mechanical cutoff saws, manual or automated venting devices, and certified container filling and handling equipment.

The most significant aspect of this unit operation is the control, venting containment, and processing of hazardous pressurized gases. Before processing, an attempt at identifying cylinder contents is a paramount safety concern and should be conducted when possible. The decompression station should be housed either in a pressure vessel or a vented chamber.

These teciriques are well-known, commercially available, and in use by industry. The equipment used in this unit operation is standard commercial equipment and will not require DT\&E. There will probably be some DT\&E 
required to address the handling of the pressurized and/or released hazardous gases within an alpha enclosure.

3.2.1.6 Thermal Decomposition. Thermal decomposition technologias such as incineration and thermal desorption have been employed in disposal of orglanic wastes. However, if the waste is saturated with heavy hydrocarbons, thermal desorption may not be effective in treating the waste, and another technique such as incineration may be needed. This process may result in the creation of noxious gases, which must be further processed before being released.

This technology has been employed at a number of hazardous waste sites (see Volume IV for more detalled discussion of incineration technologies). The application of this unit operation would require DT'E to obtain information regarding the contamination of the equipment, the degree of removal efficiency, and the desired removal efficiency. Further pilot studies should be conducted to determine the composition of off-gas that may be created in the process. These noxious off-gases may be further treated by incineration and scrubbing to neutralize their effects.

3.2.1.7 Off-Gas Treatment. The off-gas treatment unit operation treats the process stream to permit release to the environment and secondary waste stream process subsystems (e.g., condensed liquids to liquid waste stream). Because of the regilatory release requirements for the treatment of organic compounds, complex treatment methods may be required. The majer components of this unit operation may consist of assay and gas stream composition equipment, filtration (HEPA and charcoal), a spray/scrubber with chemical addition, condensation equipment, and precipitation equipment.

The process and components are all commercially available. The treatment of incinerated organic compounds may require additional DT\&E depending on the nature of the compounds being incinerated and their by-products. Some DT\&E time may be required in integration and optimization to treat a potentially wide range of influents. 
3.2.1.8 Solidification. The solidification unit operation receives fines, liquids, and organic waste and combines these using physical or chemical processes to solidify the materials. The solidified waste is placed into certified containers. The candidate processes are cement solidification, Dow process (solidification of waste in a polymer medium supplied by Dow Chemical), and other polymer processes.

The equipment typically used in these processes includes automated conveyor equipment, container handling equipment, tanks, drums/containers, pumps, slurry equipment, chemical process control equipment, incinerated by-product/ash handling equipment, and dewatering equipment.

The processes and equipment are all commercially available and in use. DT\&E may be required in the area of solidifying organic compounds with a process that will meet various regulatory requirements.

3.2.1.9 Assay/Certification. The assay/certification unit operation examines and quantifies the radioactive physical properties of the filled containers to determine proper classification and adherence to the appropriate regulations for the hazardous material and to ensure compliance with current transportation and disposal regulations. The equipment employed in this unit operation includes passive neutron detection, gamma spectroscopy/multichannel analys is equipment, gross gamma detectors, RTR, vislial inspection equipment, surface contamination measurement equipment, automated handling systems, and container labeling and tracking equipment.

This unit operation is expocted to confirm knowledge already collected during the processing of a 11 waste streans and final package operations. Final verification of waste form (I.LW or TRU) will be conducted at this time. Final labeling, material accountability tags, and transportation/storage compliance certification will be accomplished during this process step.

These techniques are we11-known. The components of this unit operation are all commercially available and currently in use. DT\&E may be required to 
provide knowledge of the waste form and development of an algorithm to accurately assay the waste.

3.2.1.10 Interim Storage. This unit operation should consist of a clean environment on a controlled area/pad and be regulated and monitored to ensure compliance with local and/or broad agency radiological regulations. The storage area is serviceable by remote and contact handling equipment with the capability of reading container labels.

These techniques are well-known. This unit operation is similar to any industrial warehouse operation.

3.2.1.11 Shipping. This unit operation is intended to be the external interface of the processing subsystems to the final waste disposition. The shipping station will prepare bills of lading for the inspected/certified waste containers. Where necessary, the containers will be over-packed to meet appropriate transportation limitations.

These techniques are well-known. This unit operation should not require any special equipment other than that normally used in current shipping cask handling and loading operations.

\subsubsection{Program Implementation Risks}

Thts section identifies major concerns associated with program implementation assuming that the Sort, Treat, and Repackage System is selected. Furthermore, risk of accomplishing the program objectives is qualitatively characterized. A summary of results and major areas of concern is shown in Table VI-3-1. Program mission and objectives are given in Volume II.

3.2.2.1 Performance objectives. Baseline cleanup standards for SDA pits and trenches at RWMC cannot be established until an ROD pursuant to the CERCLA process is reached. These standards will be derived ARARs under CERCLA, standards set by risk assessments, and the State and local statutes. Since no 


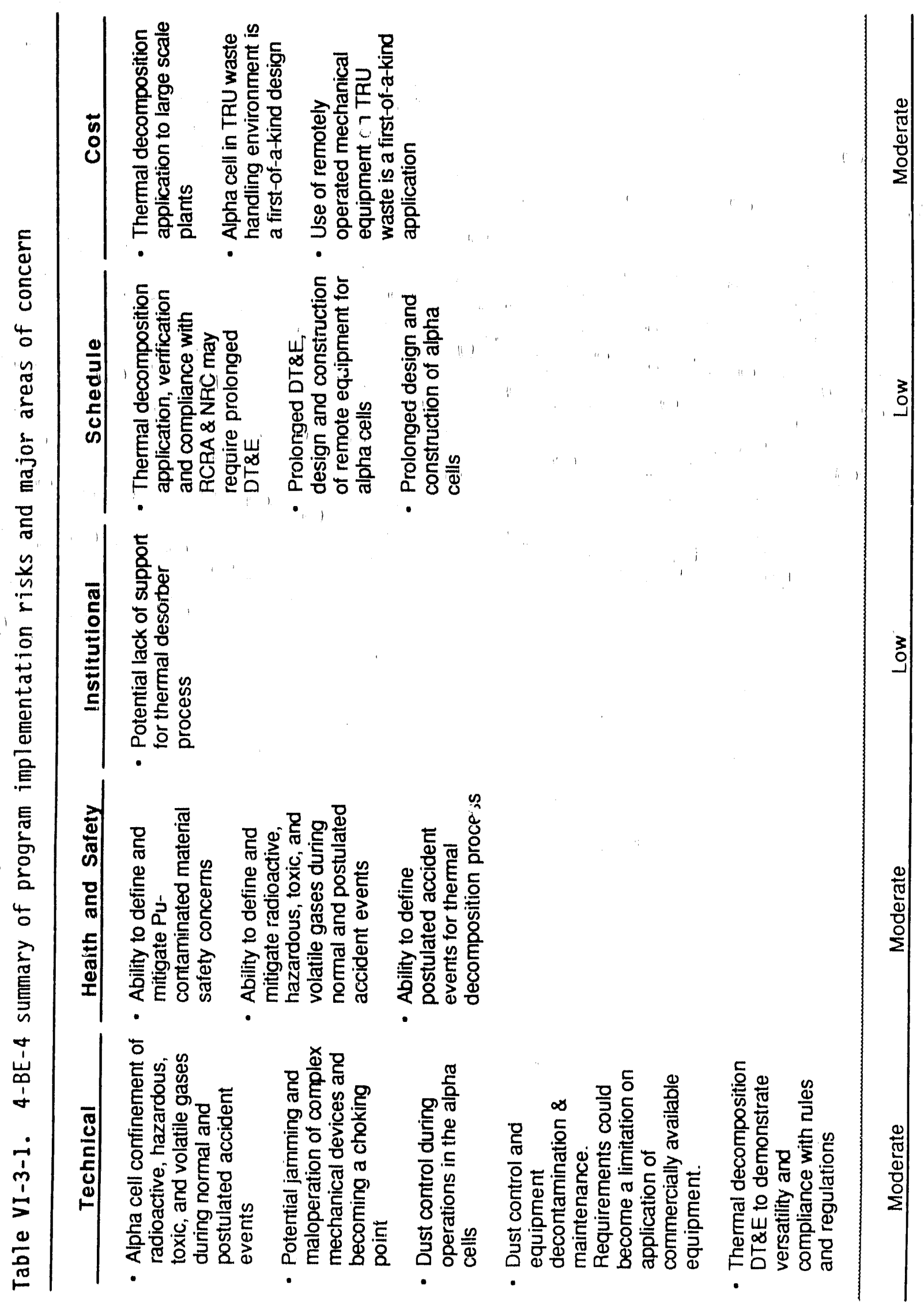


specific requirements have been formally established at this time, it is assumed that the major ARARs for this system will be RCRA rules, the appropriate NRC regulations and guides, and DOE regulations and Orders.

In the Sort, Treat, and Repackage System, the major uncertainties listed below have been identified as areas of concern in the achievement of the performance objectives:

- Thermal decomposition unit operation alpha confinement, versatility needed for buried waste streams application, and compliance with RCRA, NRC and DOE requirements. The thermal decomposition unit operation may use a thermal desorber or a commercially available incinerator. Thermal desorption technique is an emerging technology and has limited operational experience. Also, there are limited data on the application of incinerators to large-scale treatment of Pu-contaminated waste.

- Alpha cell designs for normal and postulated accidents. Alpha cells will be needed to contain Pu-contaminated dust and any radioactive, hazardous, toxic, and volatile gases that may become airborne during the waste handling and processing operations. This protection will have to be provided in normal and postulated accident events (e.g., a fire).

- Using commercial equipment in an alpha cell environment and providing ease of decontamination for maintenance. Several of the waste handling operations will use technologies that are existing but will have to be adopted for use in an alpha cell environment. This requires remote operation and ease of decontamination for maintenance.

- Potential jamming and maloperation of the complex mechanical components. Also, any of these unit operations could become potential choke points because of limited prior knowledge of waste streams and the high throughput requirements. 
- Large and complex ventiliation and filtration systems to control dust during operations in the alpha cells'.

- Unreliable operation of some of the equipment in a dusty environment. Dust control in the alpha cell environment and equipment decontamination requirements before maintenance could become limitations in the use of commercially available equipment. DT\&E efforts could become more extensive than estimated.

Based on the above discussions, it is believed that the overall risk associated with achieving the performance objectives is moderate.

3.2.2.2 Health and Safety Objectives. The key health and safety objectives for the Buried Waste Program are to (a) identify the hazards of the remedial action operation, and (b) provide measures to eliminate, control, or mitigate identified hazards. In this system, major areas of uncertainty are

- The ability to define postulated accident events (such as fire, criticality, and unforeseen release of toxic/hazardous material) for the alpha cells and provide mitigation measures to satisfy the RCRA, NRC, and DOE requirements. The unit operations associated with opening drums, boxes, waste bags, and decompression of pressurized containers provide unique safety concerns regarding potential for release of toxic, hazardous, and volatile gases.

- Mitigation of the normal and accident events (such as fire, criticality, and unforeseen release of toxic/hazardous material) for unit operations of the thermal process could become more complex than currently envisioned.

The health and safety uncertainties are largely due to the inability to characterize the incoming waste. DT\&E on characterization could provide a better confidence level. It is believed that using remote handling equipment and conducting operations inside alpha cells will enhance the mitigation measures for a majority of the normal and postulated events. This approach 
reduces the risk associated with achieving the health and safety objectives. At this stage of the system modeling, it is believed that the overall risk is low.

3.2.2.3 Institutional objectives. A key institutional objective is to involve the public, as required by CERCLA and the NEPA, in the process of selecting a remedial action for the Buried Waste Program. If the thermal desorber technique (a low-temperature thermal process) is used, then the public opposition to thermal processes is not believed to be a concern. If, however, an incineration process is used, then low public support is anticipated. In this study, it is assumed that a thermal desorber will be used. Hence, it is believed that the risk associated with achieving the institutional objectives is low.

3.2.2.4 Schedule Objectives. The objective of the Buried Waste Program schedule is to reach approval for Title II start by mid 1999. This is based on the assumptions that an ROD will be reached by the end of FY 2001. The schedule objective for completion of the Buried Waste Program remedial action is by FY 2019. The following major uncertainties in achieving these objectives have been identified:

- Thermal decomposition unit operation DT\&E work, needed to confirm the process applicability and regulatory compliance, could be prolonged.

- The alpha cells are relatively complex first-of-a-kind structures and could be subject to prolonged design and construction. However, with advanced planning, uncertainties in achieving schedule objectives could be reduced.

- Prolonged DT\&E, design, and construction of remotely operated mechanical equipment for sorting, conveying, size reduction, etc. Application of a majority of this equipment for TRU waste is a first-of-a-kind application. Again, advanced planning can reduce the uncertainties in achieving schedule objectives. 
It is believed that there is adequate time to resolve the above uncertainties and achieve the goals within the time frame allowed by the schedule objectives. Accordingly, schedule risk is believed to be low.

3.2.2.5 Cost objective. Assessment of the cost objective is a qualitative characterization based on the uncertainties involved in defining a reasonably accurate cost estimate for the system. Some of the major uncertainties are presented below:

- DT\&E, design, and construction of the unit operations of thermal decomposition could become more complex than currently envisioned. Uncertainties in defining the cost are primarily regulatory compliance and are anticipated to exist until design, based on DT\&E, is well into maturity.

- The use of an alpha cell in the given waste processing environment is a first-of-a-kind design and subject to cost overruns from prolonged design development. Major areas of uncertainty are (a) the extent of design features needed for operating in a dusty environment, (b) providing safety for postulated accident events (such as fire, criticality, and unforeseen release of toxic/ hazardous material), and (c) satisfying the RCRA, NRC, and DOE requirements. Currently, the limited information available on waste characteristics contributes to these uncertainties.

- Use of remotely operated mechanical equipment for container opening, sorting, size reduction, and handing of TRU waste is a first-of-akind application. Cost uncertainties are anticipated until design, based on DT\&E, is well into its maturity.

Based on the above discussions, the cost risk is believed to be moderate. 


\subsubsection{Unit Operations Pro and Con Analysis}

ihe following is a pro and con assessment of each unit operation of the Volume Reduction and Packaging system (4-BE-4). The pros and cons are discussed in light of the overall objectives of the Environmental Restoration Program. The compatibility of interfaces and specific areas of weaknesses in the unit operation are addressed.

3.2.3.1 Incoming (Unprocessed) Waste Receiving and Opening. This unit operation receives prepackaged waste from the Retrieval Subsystem (S-BE-4) and prepares the waste for processing. The advantage is that technologies are well-known. A disadvantage is the potential for contamination in the event of a dropped-intact drum or waste container. Also, uncapping and opening containers may involve potential airborne release of radioactive, toxic, and volatile gasses to the alpha cell.

3.2.3.2 Sorting (Nonmetal/Metal). The sorting unit operation segregates metals from nonmetals and, where applicable, further sorts by waste type (TRU, LLW, soil, etc.).

Advantages are (a) master/slave manipulators are versatile and can perform most tasks, (b) trommels and disc screens are simpla reliable devices for soil separation, (c) inductive metal detectors will separate nonmagnetic metals (stainless steel), (d) manual sorting in glove boxes is most versatile, and (e) power manipulators (e.g., electromechanical manipulators) have high lifting capacities

Disadvantages are (a) master/slave manipulators may be maintenance items and have relatively limited lifting capacities (10 to $400 \mathrm{lb}$ for standard manipulators; new ones under development should have capacities up to 1500 lb), (b) master/slave manipulators are slow and labor intensive, (c) trommels and disc screens require large operating spaces, and (d) magnetic separators will not work for austenitic stainless steels that are not magnetic. 
3.2.3.3 Volume Reduction. The volume reduction unit operation prepares the incoming" waste stream for final packaging.

Advantages are (a) a drum crusher is useful for reducing the volume of empty used drums, (b) compactors are standard size reduction equipment, (c) supercompactors can compress 211 materials including metal objects, and (d) the cryofracture process reduces both metals aid nonmetals to small sizes and does not create dust.

Disadvantages are (a) shredders and crushers may be difficult to decontaminate and may generate dust, (b) cryofracture requires research and development as there are some matertals such as stainless steel where the process does not perform well, and (c) shredders, crushers, and compactors are mechanical devices with moving parts that will be difficult to maintain in the alpha cell environment.

3.2.3.4 Sludge Drum Unloading. This unit operation prepares the incoming waste stream for final packag'ng. The drums containing sludge are opened and repackaged into clean certified containers.

An advantage is that commercial devices are available for drum opening, unliading, and repackaging. Disadvantages are (a) drum unloading systems are mechinical cavices with moving parts that will be difficult to maintain in the alpha cell environment, (b) during unloading of old sludge drums, there is a potential container fallure and splliting of the sludge, and (c) sludge may be spilled while opening sealed drums.

3.2.3.5 Decompression. An advantage is that a punch or a drill can vent a gas cylinder. A disadvantage is that a punch or drill can create a spark, which may ignite flammable vapors. Also, extreme safety measures are needed to provide protection against release of unforeseen toxic gases and liquids.

3.2.3.6 Thermal Decomposition. Thermal decomposition process wastes destroy organic compounds by various incineration techniques (see Volume IV for pro/con of various techniques). 
3.2.3.7 Off-gas Treatment. The off-gas treatment unit operation examines, quantifies, and treats off-gas. Advantages are (a) HEPA filtration is standard technology, (b) baghouse flltration and electrostatic precipitation are highly efficient for particulate collection and generate no secondary liquid wastes, and (c) wet scrubbing can remove gaseous pollutants as well as particulates. Disadvantages are that wet scrubbing generates a secondary waste stream and HEPA filters deteriorate over time and must be replaced periodically.

\subsubsection{Solidification. The solidification unit operation solidifies} fines, liquids, and organic waste by-products using physical or chemical processes.

Advantages are (a) using Portland cement is a simple, well-known process that is readily available and works best for inorganic contaminants, but also works with 011 and grease, and (b) lime-based pozzolanic systems have similar pros as Portland cement and can work better with organics but not oils.

Disadvantages are (a) Portland cement and pozzolanic systems are not exceptionally leach resistant [the ratio of waste loading to cement is fairly low (one to one)] and these systems are not suitable for vocs, (b) thermoplastic resins require the waste to be dried before solidification, the resin product can be damaged by fire, and organic compounds may vaporize during heating in the solidification process, (c) organic poiymers are highly viscous, which makes them difficult to process, and costs are about five times those for cement, and (d) Portland cement generates dust.

3.2.3.9 Assay/Certification. The assay/certification unit operation examines and quantifies the radioactive properties of the filled containers to classify and ensure compliance with regulations for final disposal.

An advantage is that instruments for certification are available. Disadvantages are that changing WIPP acceptance criteria may change the instruments required, and production-scale instrumentation with high throughput and reliability needs development.

VI -103 


\subsubsection{Unit Operations Lead-Time Estimates}

The lead-times are estimated for each unit operation that may require DT\&E before landing in the field and are shown in Table VI-3-2. The development of a lead-time required for DT\&E is based on a qualttative judgment and should be further refined.

\subsubsection{Rough Order of Magnitude Cost Estimates}

ROM costs were developed for the Volume Reduction and Packaging System (4-BE-4) using assumptions given in Section 1. The costs are summarized in Table VI-3-3.

The assumptions and qualifications used in the preparation of the ROM estimate for this system are as follows:

- Special site preparation costs are not included (e.g., drainage, substations, roadwork, and other utilities).

- Owner's costs such as environmental impact report costs, 1abor, and overheads are not included.

- The estimate is based on first-quarter 1991 wage and price levels.

- The facility areas are developed based on conceptual layout of process equipment. Allowances for administrative and remote operation facilities are not included.

- The areas shown in the F\&OR general arrangement were adjusted to account for the unit operation capacity.

- The equipment scope was based on conceptual process flow diagrams.

- Equipment pricing is based on conventional commercial construction. 


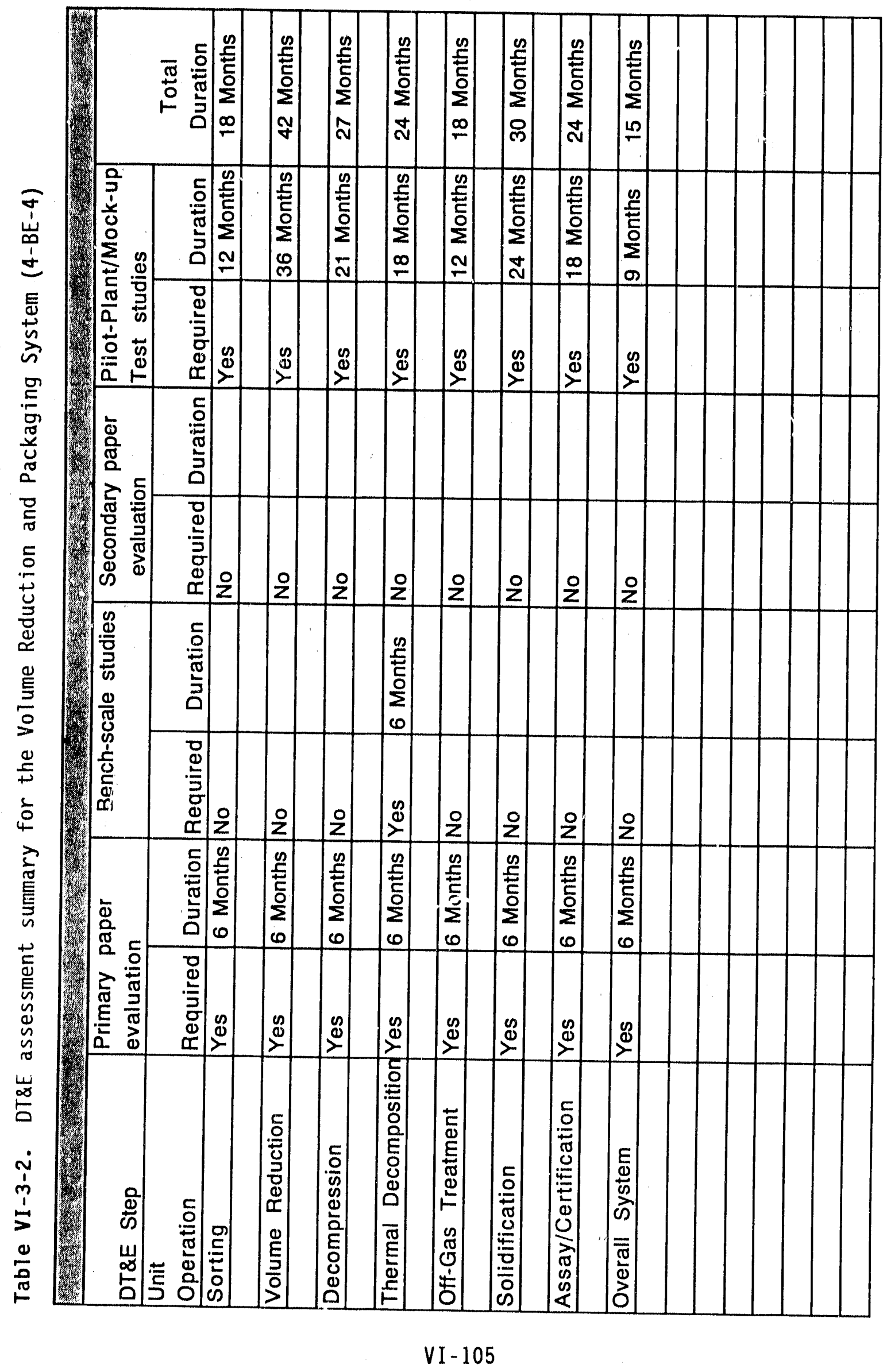


Table VI-3-3. Rough order of magnitude cost estimates (4-BE-4) ${ }^{a}$

\begin{tabular}{|c|c|c|c|}
\hline $\begin{array}{l}\text { Cost } \\
\text { Code } \\
\end{array}$ & Cost Items & $\begin{array}{c}\text { Normallzed } \\
\text { Co8t } \\
(\$ \times 1000) \\
\end{array}$ & $\begin{array}{c}\text { Modifled } \\
\text { Cost } \\
(\$ \times 1000) \\
\end{array}$ \\
\hline 1.0 & Studied and bench scale cosis & & \\
\hline 1.1 & Manpower costs during research & $\$ 1,600$ & $\$ 1,600$ \\
\hline 1.2 & Equipment costs & $\$ 1,000$ & $\$ 1,000$ \\
\hline 1.3 & Installation costs & $\$ 250$ & $\$ 250$ \\
\hline \multirow[t]{2}{*}{1.4} & Contingency & $\$ 713$ & $\$ 713$ \\
\hline & Subtotal 1.0 & $\$ 3,563$ & $\$ 3,563$ \\
\hline 2.0 & Demonstration costs & & \\
\hline 2.1 & Manpower cost during construction & $\$ 3,200$ & $\$ 3,200$ \\
\hline 2.2 & Design $\operatorname{cost}(30 \%$ of 2.5$)$ & $\$ 2,277$ & $\$ 2,277$ \\
\hline 2.3 & Inspection cost $(7 \%$ of 2.5$)$ & $\$ 531$ & $\$ 531$ \\
\hline 2.4 & Project administration ( $10 \%$ of 2.5 ) & $\$ 759$ & $\$ 759$ \\
\hline 2.5 & Construction cost & & \\
\hline 2.5 .1 & Bullding structure costs & $\$ 1$ & $\$ 1$ \\
\hline 2.5 .2 & Equipment costs & $\$ 6,000$ & $\$ 6,000$ \\
\hline \multirow[t]{2}{*}{2.5 .3} & Indirest $(20.9 \%$ of 2.5$)$ & $\$ 1,590$ & $\$ 1,590$ \\
\hline & Subtotal of 2.5 & $\$ 7,591$ & $\$ 7,591$ \\
\hline 2.6 & Construction management costs $(27.8 \%$ of 2.5$)$ & $\$ 2,179$ & $\$ 2,179$ \\
\hline \multirow[t]{3}{*}{2.7} & Contingency & $\$ 4,134$ & $\$ 4,134$ \\
\hline & Subtotal 2.0 & $\$ 20,672$ & $\$ 20,672$ \\
\hline & & & \\
\hline 3.0 & Production construction costs & & \\
\hline 3.1 & Design cost $(30 \%$ of 3.4$)$ & $\$ 73,270$ & $\$ 35,548$ \\
\hline 3.2 & Inspection cost $(7 \%$ of 3.4$)$ & $\$ 17,096$ & $\$ 8,295$ \\
\hline 3.3 & Project administration ( $10 \%$ of 3.4 ) & $\$ 24,423$ & $\$ 11,849$ \\
\hline 3.4 & Construction cost & & \\
\hline 3.4 .1 & Building structure costs & $\$ 154,890$ & $\$ 55,490$ \\
\hline 3.4 .2 & Equipment costs & $\$ 38,180$ & $\$ 38,180$ \\
\hline \multirow[t]{2}{*}{3.4 .3} & Indirect $(20.9 \%$ of 3.4$)$ & $\$ 51,164$ & $\$ 24,823$ \\
\hline & Subtotal of 3.4 & $\$ 244,234$ & $\$ 118,493$ \\
\hline 3.5 & $\begin{array}{l}\text { Construction management costs and construction management } \\
\text { reserve }(26.5 \% \text { of } 3.4)\end{array}$ & $\$ 70,095$ & $\$ 34,007$ \\
\hline \multirow[t]{3}{*}{3.6} & Contingency $(25 \%$ of 3.1 through 3.5$)$ & $\$ 107,280$ & $\$ 52,048$ \\
\hline & Subtotal 3.0 & $\$ 536,399$ & $\$ 260,240$ \\
\hline & Total Capital Cost $(1.0,2.0$, and 3.0$)$ & $\$ 560,633$ & $\$ 284,475$ \\
\hline 4.0 & Annual operating and maintenance costs & & \\
\hline 4.1 & Operating costs & $\$ 34,000$ & $\$ 34,000$ \\
\hline 4.2 & Utillity costs & $\$ 8,000$ & $\$ 8,000$ \\
\hline 4.3 & Material costs & $\$ 13,000$ & $\$ 13,000$ \\
\hline 4.4 & Maintenance costs & $\$ 15,000$ & $\$ 15,000$ \\
\hline \multirow[t]{2}{*}{4.5} & Contingency & $\$ 17,500$ & $\$ 17,500$ \\
\hline & Subtotal 4.0 & $\$ 87,500$ & $\$ 87,500$ \\
\hline TOTAL & 10 Years Operating and Maintenance Costs & & $\$ 875,000$ \\
\hline
\end{tabular}


- Minimal allowance (e.g., one-of-a-kind demonstration) has been included for remote operation and any nuclear quality assurance program cost.

- An allowance for process bulks are included at $30 \%$ of the cost to account for electrical, piping, and local control requirements.

- The cost estimate is based on all technologies with the exception of vitrification and cryofracture; one-and-a-half years of demonstration (system integration) are assumed.

- The demonstration of the system is assumed to occur within existing facilities.

- Equipment costs include material, fabrication, delivery, inspection, and installation costs.

- Costs for widening or strengthening existing roads for construction are not included.

- An adequate supply of labor is assumed to exist within the local area.

- Testing and initial startup costs are not included.

- Operating and maintenance costs are based on $15 \%$ of production construction costs.

- Cost estimates are based on nominal costs associated with the best currently available technology considered. The lowest technology and the state-of-the-art systems were not considered in the cost model. 
- The cost estimate does not include the cost of the Retrieval, Metal Decontamination and Sizing, Low-Level Waste Processing, or the Soils Processing Subsystems.

Strengths and weaknesses of the cost estimate include the following:

- Subsystem costs may vary between systems depending on the technologies employed.

- The cost estimate is based on relatively well-known technologies. No provision was made for research and development associated with state-of-the-art technologies such as cryofracture.

\subsubsection{System Evaluation Results}

The purpose of this section is to provide an overall evaluation on a system basis and to identify the major considerations (both advantages and disadvantages) resulting from the assessments in the previous sections. This includes an evaluation of the ability to integrate the various unit operations into a smooth, well-functioning system.

Specific areas addressed include the identification of system major considerations, a qualitative judgment rating of performance measurables, and a summary of DT\&E needs.

\subsubsection{Identification of System Major Considerations.}

- Current status: The techniques employed in this sj'stem, except for cryofracture, are well-known, commercially available, and in current use by industry. The cryofracture process is currently used, but on a more limited scale than that of other technologies in the system. The thermal decomposition unit operation, while having been employed previously, will require detailed information regarding the composition of the input waste stream to achieve desired 
efficiencies of removal and to permit integration with other unit operations.

- Risk Assessment: There is an implementation risk associated with the alpha cell enclosure and accessibility to repair or maintain the equipment. It is 1ikely cryofracture will not perform well with some types of stainless steels, and there may be incompatibilities with the waste stream composition and the solidification system. The decompression unit operation may pose safety hazards.

- Pro/con assessment: The significant pro for this system is that the processes employed by the system are all in use and we11-known. The significant con for this system is that the thermal decomposition process may require testing of the input streams and may require tuning for accommodation of different waste compositions.

- Schedule: The technologies, except for solidification and cryofracture, do not require significant DT\&E. Development/ demonstration time is required for integration of all unit operations.

- Cost estimate: The costs for this system should be wel1-known because the technologies are in current use.

3.2.6.2 Performance Measurables Rating. These measurables represent the top level of performance requirements that will be allocated and then applied to appropriate elements of the system in subsequent phases of the program. Table VI-3-4 provides a qualitative assessment of how well the Volume Reduction and Packaging System satisfies these performance measurables. 


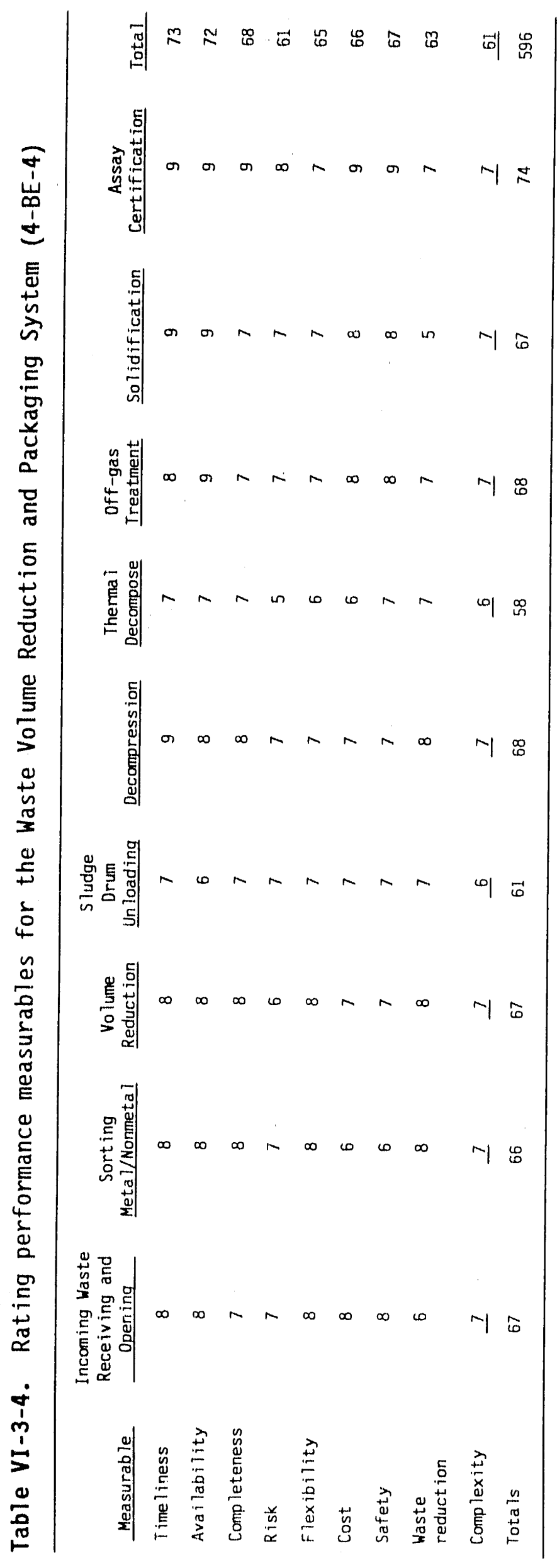

VI -110 


\subsubsection{Summary of Demonstration, Testing, and Evaluation Needs}

The DT\&E needs for each unit operation and for the overall system have been summarized in Table VI-3-5. This table provides a ready reference of DT\&E needs in the final system evaluation and for comparison purposes with other systems.

\subsection{Recommendation for the System}

The Volume Reduction and Packaging System essentially uses existing technology to collect, sort, size reduce, solidify, and package the retrieved waste to meet current burial standards. There is no physical conversion of the input streams except for the thermal decomposition and solidification processes. The technologies employed are all currently available permitting an early start on design, fabrication, and installation. It appears that much of the RWMC waste could be processed with these technologies today. The key advantage of this system model is its volume reduction feature, which was not considered in 4-BE-2 system.

Several issues that will require further DT\&E include (a) further efforts on thermal decomposition and solidification processes to determine compatibility with the RWMC waste streams, (b) the system as a whole will require fine tuning of all the selected technologies to produce the desired end results, (c) an analysis of the queuing of the waste stream to determine capacities of components for unit operations, (d) the integration of the process streams should be reviewed to ensure compatibility, and (e) consideration should be given to on-line sensors that monitor and report status and progress of waste stream processing.

This study helped to characterize and define a number of alternatives for the unit operations of this system. The evaluations conducted under this study conclude that DT\&E is required. Qualitative judgments were used in developing the extent of DT\&E required. A more detailed assessment is needed to draw a definitive conclusion on DT\&E programs and technology selection. 


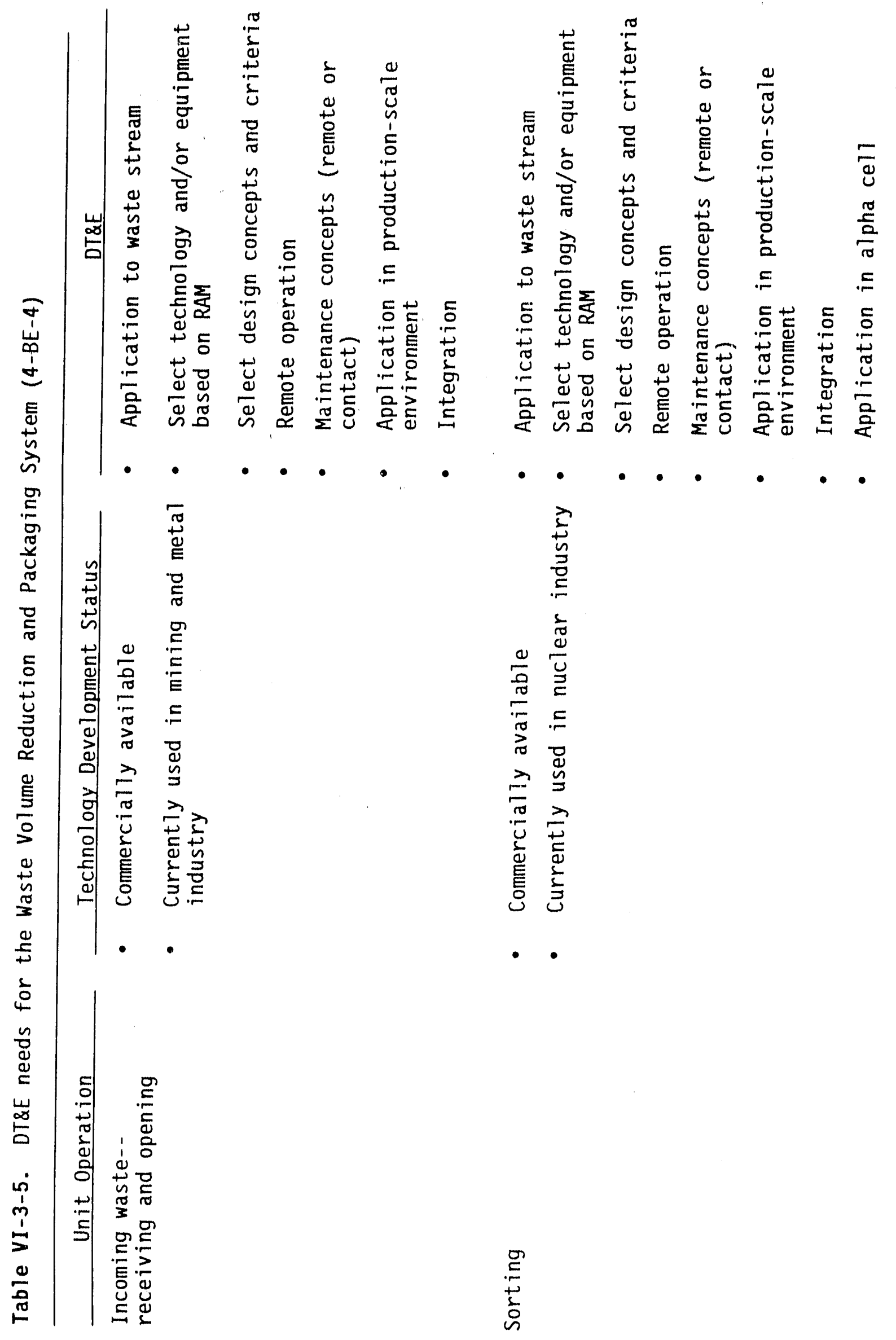




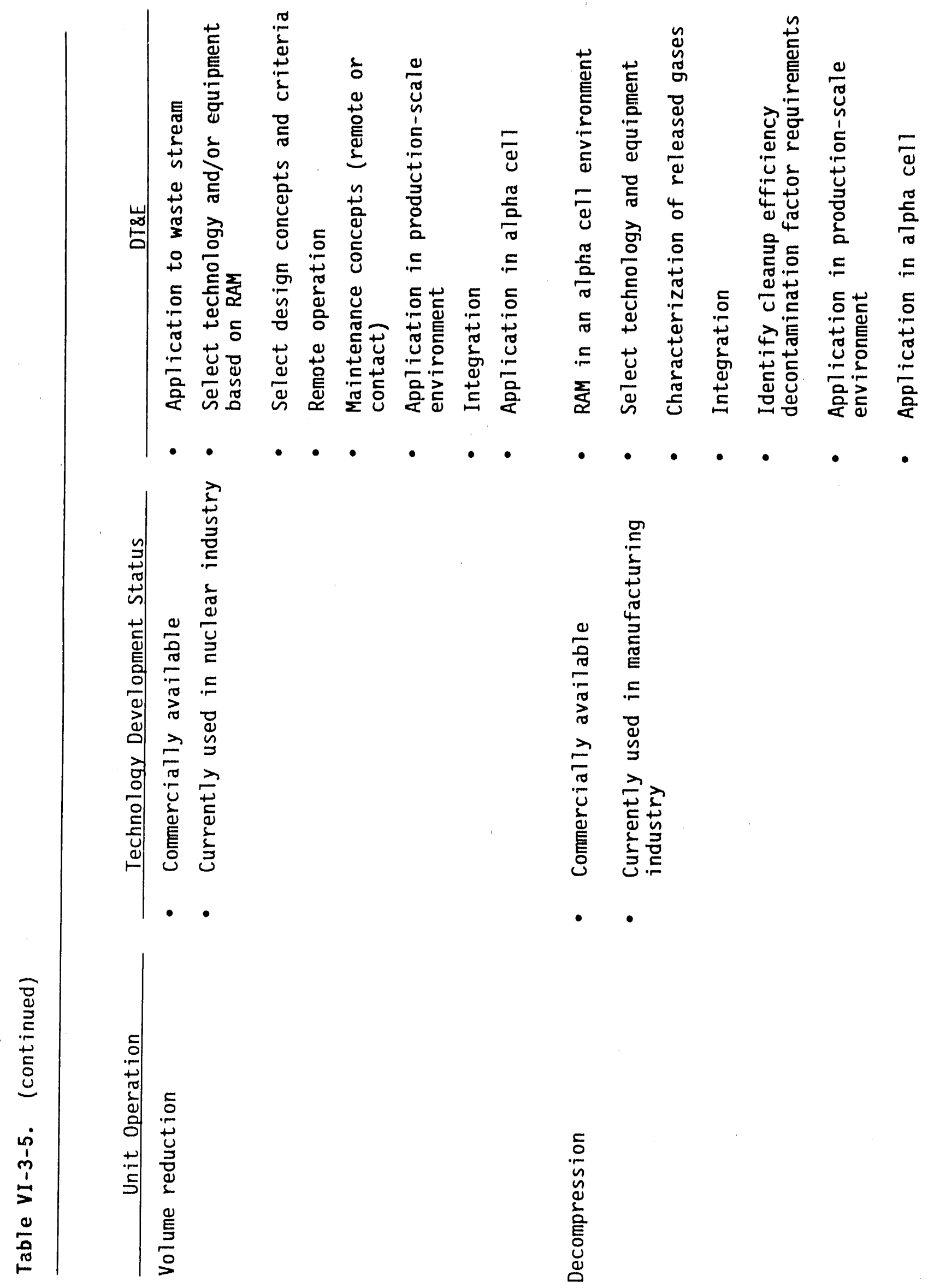



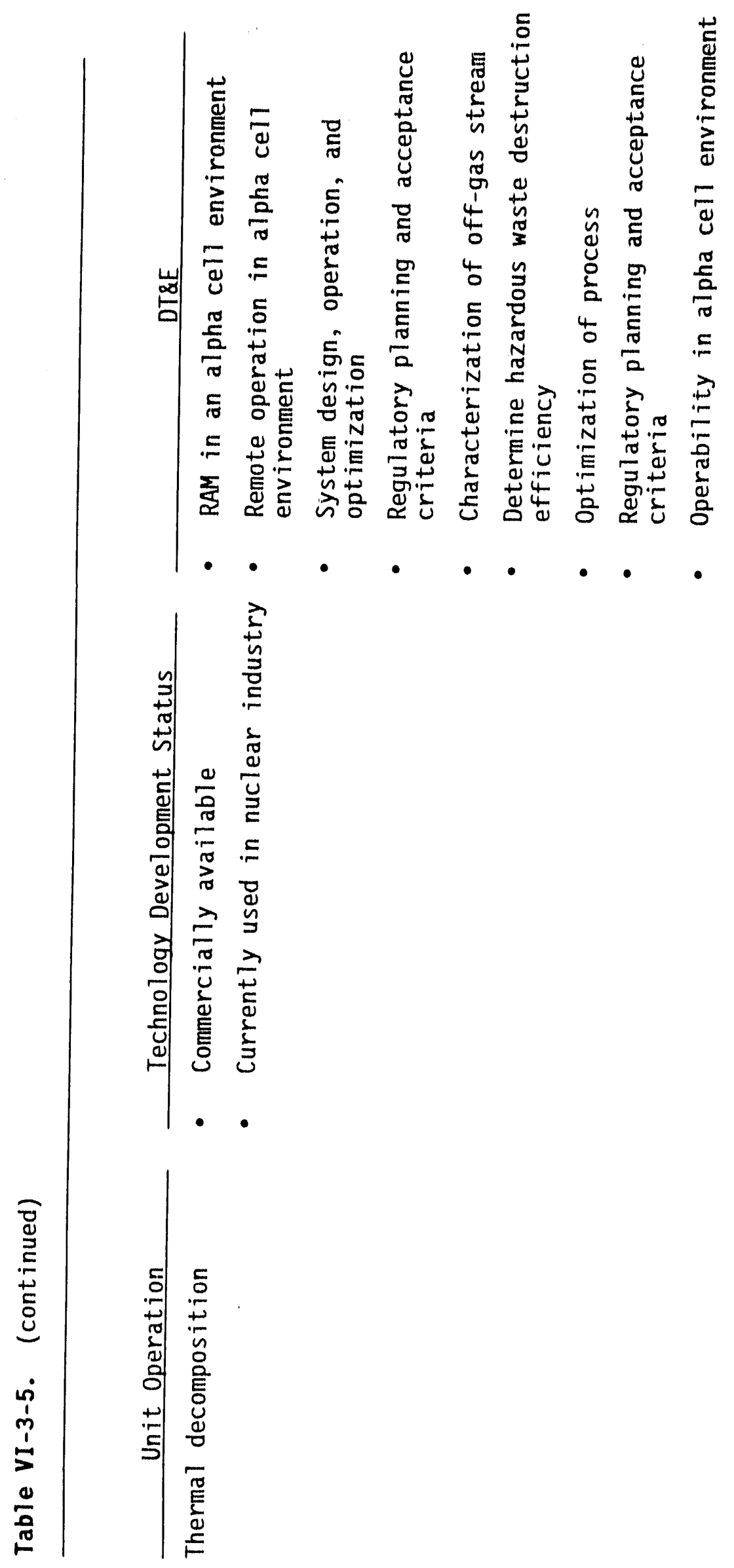


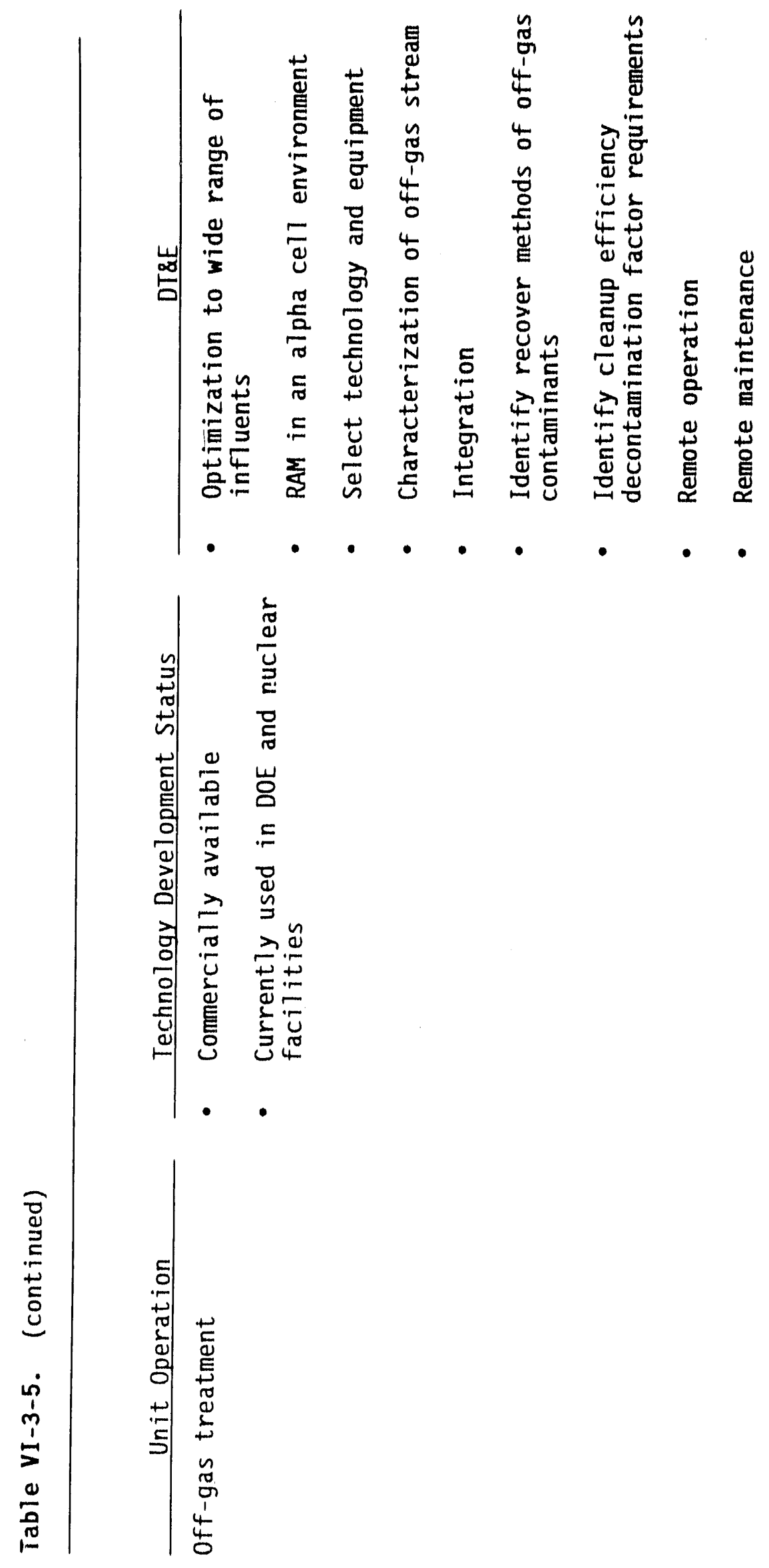




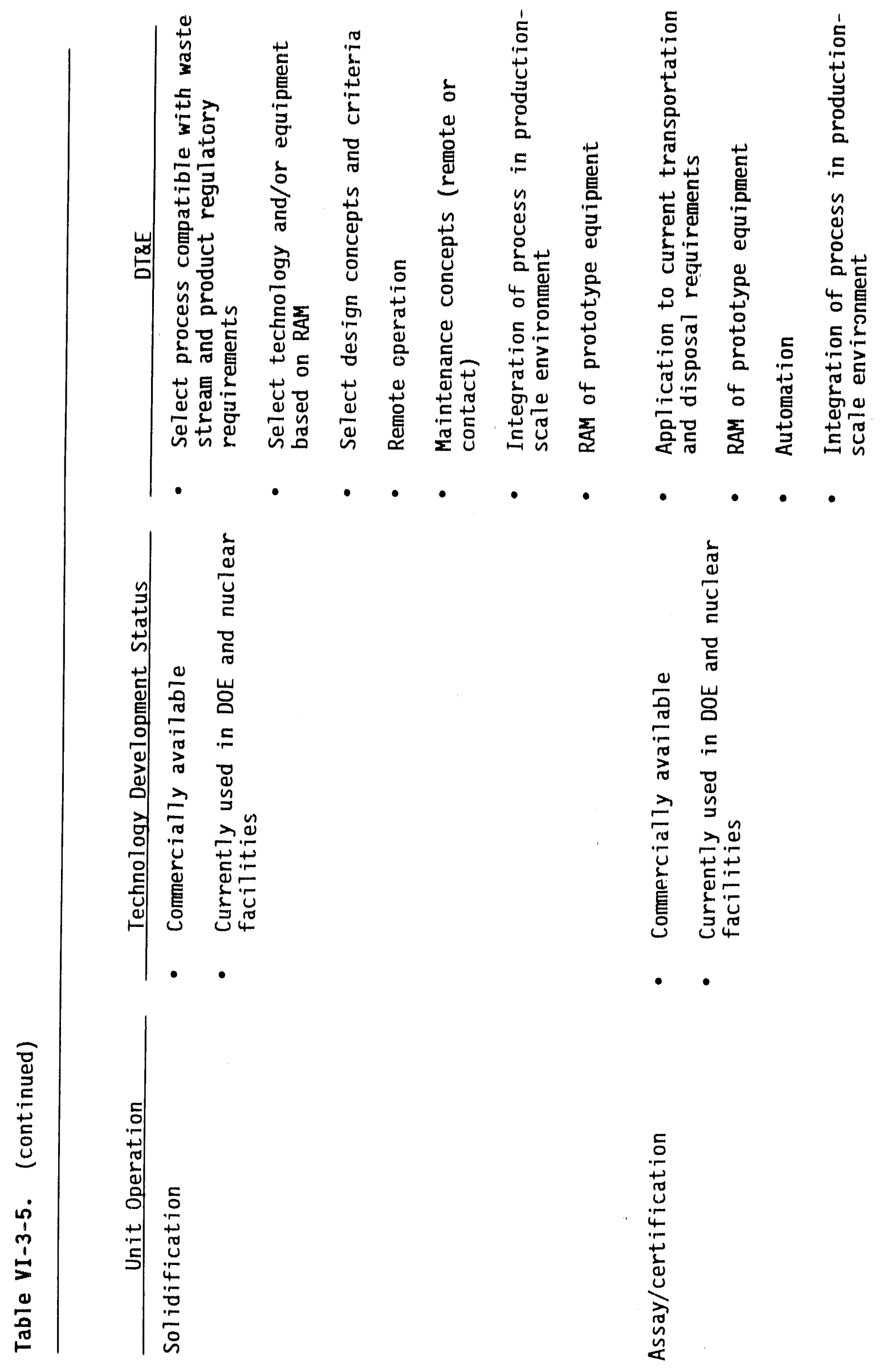




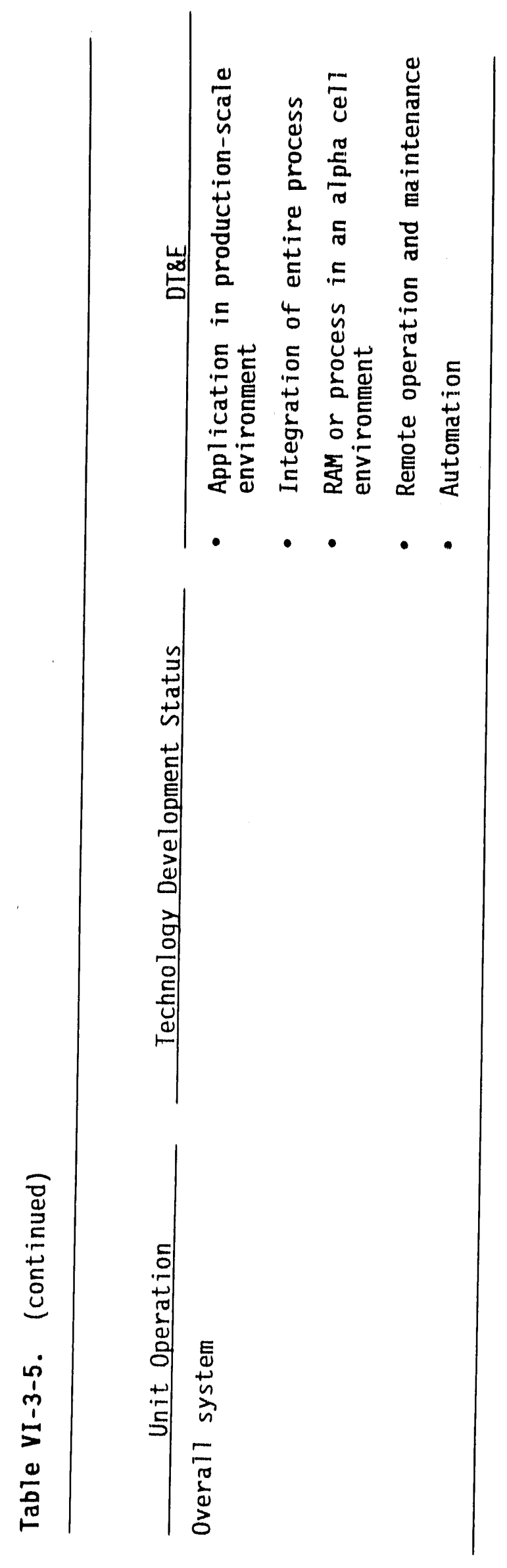


Risk assessments for implementing the program are qualitative and Judgmental and are based on the assumption that wastes having dangerous physical or chemical characteristics (e.g., pyrophoric metals and gas cylinders containing toxic, volatile, and reactive gases) are now being processed. A more detalled definition of the incoming waste will be needed to perform a complete risk assessment, and significant changes in the composition of the waste may impact the technology selected and the general arrangement of the facilities.

The Volume Reduction and Packaging System offers the processing of waste with volume reduction and packaging for direct burial. 


\section{BIBLIOGRAPHY}

Arrenholz, D. A., 1990, In Situ Vitrification Program Treatability Investigation Program Report, EGG-WTD-9383, December.

Arrenholz, D. A., and J. L. Knight, 1991, A Brief Analysis and Description of Transuranic Wastes in the Subsurface Disposal Area of the Radioactive Waste Management Complex and INEL, EGG-WTD-9438, February.

AWC Inc., 1989, TRU Clean: A Process for Decontaminating Radioactive and Hazardous Soils.

Boehmer, A. M., et al., 1986, "Solidification of Hazardous and Mixed Radioactive Waste at the Idaho National Engineering Laboratory," Proceedings of the 1986 Symposium on Waste Management, Tucson, Arizona, March.

Borham, B. M., et al., 1986, "Handling of Transuranic Waste for Volume Reduction by Incineration," Proceedings of the 1986 Symposium on Waste lianagement, Tucson, Arizona, March.

Bowen, M. D., et a1., 1978, "A Vertical-Bed Pyrolysis System, Solid Waste and Residues Conversion by Advanced Thermal Processes," 175th Meeting of the American Chemical Society, Anaheim, Caliiornia, March 13-17.

Bramlitt, E. T., 1988, "Plutonium Mining for Cleanup," Health Physics, 55, 2, August, pp. 451-453.

Cleveland, J. M., 1970, The Chemistry of Plutonium, Garden and Breech Publications: New York, pp. 48-61.

Cwynar, J. C., et a1., 1986, "Retrofit and Operation of Low-level Radwaste Solidification System," Proceedings of the 1986 Symposium on Waste Management, Tucson, Arizona, March.

Deininger, J. P., 1990, "Developments in Transuranic Element Polishing from Radioactive Wastewaters Using Ferrate Chemical Techrology, "Waste Management '90 Conference, Tucson, Arizona, March.

Edinborough, C. R., 1990, Processing Criteria for TRU Removal from RWMC Stored Waste, ERDP 2802, August 15.

EPA, 1989, Guide for Conducting Treatability Studies Under CERCLA, $\mathrm{EPA} / 540 / 2-89 / 058$, December.

Francis, C. J., and T. M. Starr, 1990, "The ANF LLW Incinerator Design \& Start-Up," Fourth Annual Symposium on Incineration of Industrial Wastes, Knoxville, Tennessee. 
Freeman, H. M., 1989, Standard Handbook of Hazardous Waste Treatment and Disposa7, McGraw Hi11: New York.

Geosafe Corporation, 1989, Application and Evaluation Considerations for In Situ Vitrification Technology: A Treatment Process for Destruction and/or Permanent Immobilization of Hazardous Materials, GSC 1901, April.

Jessop, D., et al., 1986, "Design, Installation, Testing and Start-up of a Material Handling System at the West Valley Demonstration Project," Proceedings of the 1986 Symposium on Waste Management, Tucson, Arizona,
March.

Koegler, S. S., R. K. Farnsworth, R. K. Nakaoka, and S. 0. Bates, 1989, Vitrification Technologies for Weldon Spring Raffinate Sludges and Contaminated Soils Phase 2 Report: Screening of Alternatives, PNL-7125,
November.

Nielson, R. K., et al., 1989, "Low Temperature Thermal Treatment of Volatile Organic Compounds, " 1989 Incineration Conference, Knoxville, Tennessee,
May.

Palmer, C. A., 1989, "X-TRAX Y-12 Sludge Detoxification Demonstration," 1989 Incineration Conference for Chemical Waste Management, Knoxville, Tennessee, May.

Penberthy, H. L., 1990, Full Scale Demonstrating In Situ Vitrification Showing the Fatal Flaw Which is Called Vapor Retreat, June.

Perry, R. H., and C. H. Chilton (eds.), 1973, Perry's Chemical Engineer's Handbook, Fifth Edition, Table 25-50.

Peters, M. S., and K. Timmerhaus, 1990, Plant Design and Economics for Chemical Engineers, 4 th edition, New York: McGraw-Hill.

Stewart, J.A., and D. L. Charlesworth, 1986, "Design and Operation of a Remotely Operated Plutonium Waste Size Reduction and Material Handling Process," Waste Management-'86, Proceedings of the Symposium on Waste Management at Tucson, Arizona, March 2-6.

Theodore, L., and T. Reynolds, 1987, Introduction to Hazardous Waste Incineration, Wiley-Interscience.

Vietzke, H., Minimizing of Organic Waste by Pyrohydrolysis.

Wheelwright, E. J., L. A. Bray, and J. L. Ryan, 1987, Development of the CEPOD Process for Dissolving Plutonium Oxide and Leaching Piutonium from Scrap or Wastes, PN-6483. 

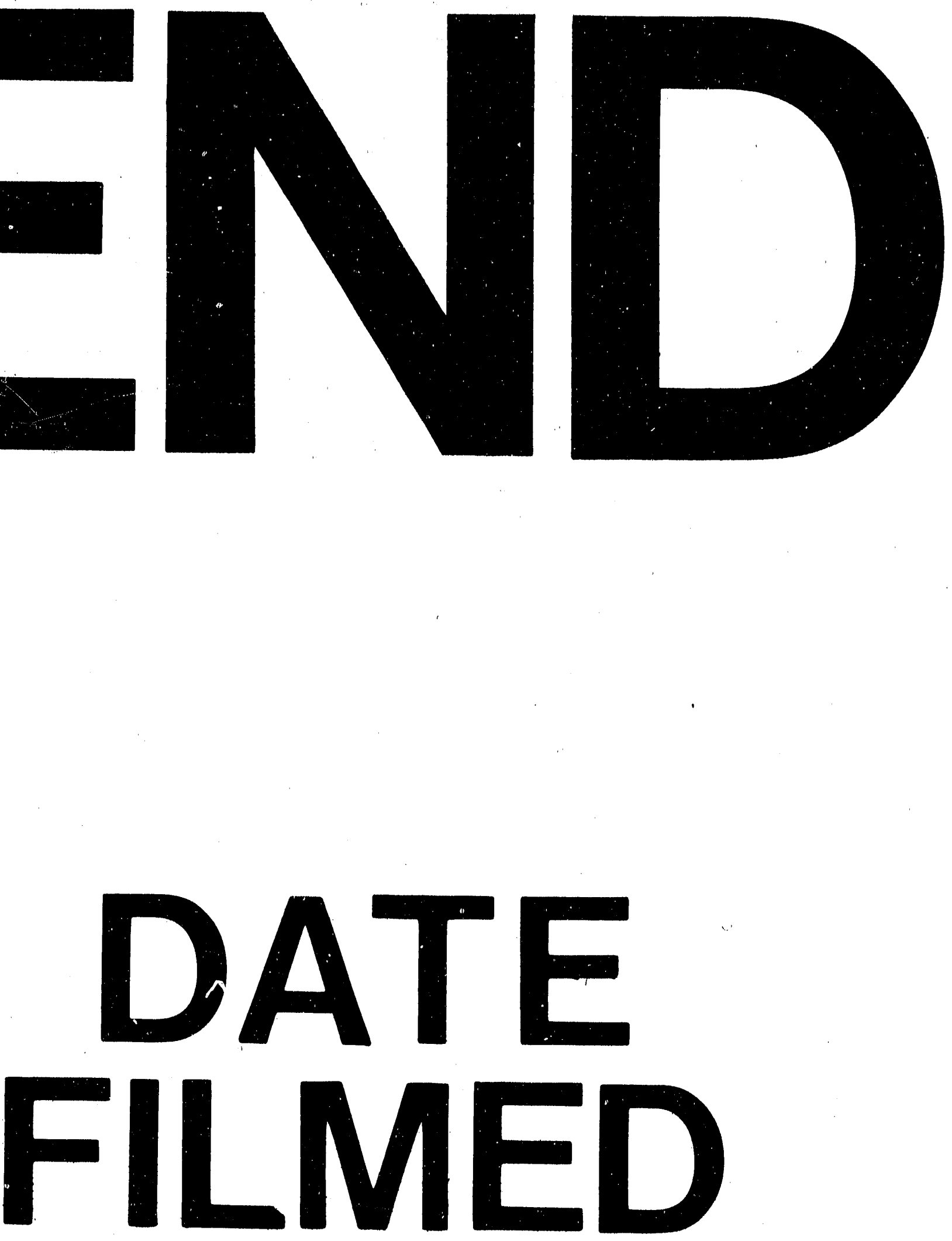

6

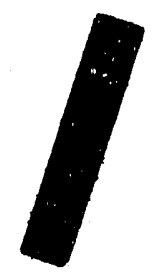

15

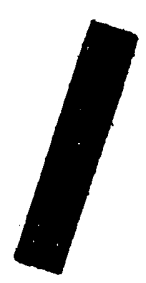

92 
